Title Page

\title{
New Multiphase Compositionally Complex Alloys Driven by the High Entropy Alloy Approach
}

\author{
Anna M. Manzoni ${ }^{1}$, Uwe Glatzel ${ }^{2}$ \\ ${ }^{1}$ Helmholtz-Zentrum Berlin für Materialien und Energie GmbH, D-14109 Berlin, Germany \\ ${ }^{2}$ Metals and Alloys, University Bayreuth, D-95447 Bayreuth, Germany \\ Email: addresses: anna manzoni@gmx.net, uwe.glatzel@uni-bayreuth.de
}

Corresponding author: Uwe Glatzel

Keywords: high entropy alloys, compositionally complex alloys, tensile test, mechanical properties, overview

\begin{abstract}
The discovery of high entropy alloys at the turn of the millennium lead to a multitude of investigations of different types, focus and aims. With an increased knowledge of the new family of materials, it was possible to make a separation into true single phase high entropy alloys (HEA) and multi-phase compositionally complex alloys (CCA), which both fulfil the initial definition criteria. This review focuses on CCA that have been investigated and developed with a mechanical application in mind. A special importance is attributed to the mechanical testing methods, and priority is given to tensile testing at both room temperature and up to $700^{\circ} \mathrm{C}$. Precise microstructural characterization techniques like transmission electron microscopy and/or atom probe tomography ensure the determination of small scale phases, which could be overlooked when using only scanning electron microscopy and/or X-ray diffraction. Comparison of the investigations that meet these criteria are summarized in several tables and figures.
\end{abstract}




\section{Introduction}

Since the discovery of high entropy alloys at the turn of the millennium by Yeh et al. [1-3], Cantor et al. [4, 5], and Ranganathan [6], a new approach has been pushed forward in this class of materials in the last few years. For the first few years all alloys that met the original definition of high entropy alloys (more than five elements, almost equiatomic composition, similar atomic radii, simple crystal structures) have been called high entropy alloys (HEA) and the investigations of these alloys have expanded rapidly. Recently there has been a separation into those alloys having a single phase microstructure, as was expected by the first developers, and those that contain more than one phase. The second group can be named compositionally complex alloys (CCA). In many papers, especially the early ones, these are unwanted side effects on the way to the finding of a single phase alloy. The rare single phase alloys, like for example the most famous "Cantor alloy" [5], equiatomic $\mathrm{CoCrFeMnNi}$, have been treasured and studied extensively under numerous aspects $[7,8]$.

Most description of CCA have happened because of the following four aspects:

- There is a general interest in these new alloy families, driven by an overall curiosity about their behaviour. A huge database has been established by changing one element in an alloy, or by changing the heat treatment, or by adding additional elements. There is usually no explanation given why the investigated CCA is more or less interesting than an HEA

- A large number of CCA are accidental CCA - usually the authors were not looking for a multiphase alloy.

- Some CCA are misleadingly interpreted as single-phase HEA, because the experiment, e.g. the resolution, is not precise enough. Small particles or very low volume fractions are not detected.

- The investigation of mostly as-cast alloys, or even alloys produced with very high cooling rates, cannot give clear evidence of the nature of the alloy. A homogenization is necessary to establish a database of as close as possible to an equilibrium state, which should define an alloy before the kinetic aspect is investigated. This approach is not often met and thus the classification of the alloys is very challenging.

These four points imply that there are only a few, quite recent approaches which consider these CCA as of their own kind, i.e. studies which want to make use of properties that are linked to the multi-phase concept. In addition to the "classical" composition variations within the HEA/CCA definition, the use of minor elements for solid solution strengthening, or precipitate former for precipitation strengthening, have been other recently employed methods for designing new HEA and CCA with enhanced properties.

\subsection{Difference to HEA}

As the research on this new family of alloys evolved, it became clear that a distinction needed to be made between the single-phase alloys (HEA) and those that contain several phases (CCA), see Table 1. Their differences and similarities have also been the centre of attention of the new HEA - CCA priority program of the German Research Foundation, for more details see [9]. These points will also be the basis for this manuscript. Further clarifications will be made in section 2 .

\begin{tabular}{cc}
\hline Compositionally Complex Alloys (CCA) & High Entropy Alloys (HEA) \\
\hline $\begin{array}{c}\text { at least } 5 \text { different elements } \\
\text { molti-phase system allowed }\end{array}$ & $\begin{array}{c}\text { very close to equiatomic composition } \\
\text { single-phase }\end{array}$ \\
\hline
\end{tabular}




\begin{tabular}{cc}
\hline complex structures (intermetallic phases) allowed & in general: simple crystal structure with no \\
chemical ordering
\end{tabular}

Table 1: Definition and differences of CCA and HEA

\subsection{Alloy development for improving the mechanical properties}

This review focuses on alloys that are anticipated for a mechanical application. Electrical, magnetic or other properties have been investigated to a much lower extend, and are not included in this review.

When developing a new alloy, a common approach is to improve an already existing one. In the case of the HEA/CCA family, the most usual improvement path concerns the mechanical properties, which often consists in enhancing hardness or tensile strength. It is common knowledge that there are six main strengthening mechanism for alloys:

- $\quad$ solid solution strengthening (controlled mainly by composition)

- work hardening (controlled mainly by processing route)

- precipitation hardening (composition)

- grain boundary strengthening (processing route)

- transformation hardening (composition and processing route)

- dispersion hardening (processing route (powder metallurgy) and composition (powder mixture))

All the methods use the disturbances in the dislocations' pathways but still making a dislocation movement possible to ensure some ductility.

The first mechanism, i.e. solid solution strengthening, can be used in both HEA and CCA. Solid solution strengthening is indeed the most important mechanisms for HEA. Solid solution strengthening by interstitials, such as $\mathrm{N}, \mathrm{O}$, or $\mathrm{C}$, has not been investigated thoroughly in the HEA/CCA community yet.

Precipitation hardening is the one mechanisms that makes the difference between HEA and CCA. The introduction of a second phase for strengthening purposes has been applied for centuries, i.e. by cementite in steels or the well-known $\gamma^{\prime}$ phase in nickel-base superalloys. This approach need a good knowledge of the alloy's composing elements and their thermodynamic relationships. Generally, an equilibrium state of the alloy is aimed for. This approach will be called "the elemental approach" and will be treated in detail in 1.2.1.

Grain boundary strengthening and work hardening can be considered as a common mechanism for both HEA and CCA. Until now, there has not been an investigation that used a work hardened material. Some samples have been recrystallized, leading to a smaller grain size [13-15]. Another grain refinement method, e.g. by adding the grain refining element boron, has - to our knowledge - only been reported by one group [16]. This method of grain refinement can be used for all types of alloys, independent on their being HEA or CCA. Until now, there is no report on whether this method works better or worse on HEA or CCA. In this manuscript, it will be treated as "the mechanical approach" (see section1.2.2). 
The transformation mechanisms, common in steels, usually corresponding to the austenite phase transforming into the non-equilibrium martensitic phase due to rapid cooling. Until now, this mechanism has not been used often in CCA or HEA, except for the work by Li et al. [17, 18]. This work will be presented separately in section 3.3.1a).

Another interesting mechanism is twinning or martensite formation, which is another way of enhancing the material behaviour by making the correct choice of composition. It is important that the stacking fault energy is approaching zero [19] in order to easily launch the twinning process. The activation energy for twinning needs to be provided, e.g. by mechanical deformation and/or temperature change. The first has been observed in several HEA [14, 20] and CCA [21] and is usually obtained by severe plastic deformation. As this approach leads too far from the material equilibrium condition, it will not be considered in this review (see also section 1.2.3).

The twinning effect launched by a change of temperature can be used as a shape memory effect. It works best in single phase alloys. In terms of HEA/CCA, it would thus be more interesting to search for this effect in HEA and not CCA. The effect has been observed by several groups in both HEA and occasionally in CCA [22-25]. However, as there is only little available data and as this effect is very particular, it will also not be considered in this review.

\subsubsection{The elemental approach: CALPHAD-examples}

In order to avoid the costly casting process of many alloys, it has been found useful to employ the CALPHAD approach to form a general idea of the alloy behaviour. The calculation of low temperature phases, i.e. below $600^{\circ} \mathrm{C}$ for many high temperature materials, has been found faulty in many cases, but phase stabilities above $600^{\circ} \mathrm{Ccan}$ often be trusted in a qualitative way. Figure 1 gives three examples of calculated phase diagrams, using the ThermoCalc software [26] and the TTNi7 database [27].
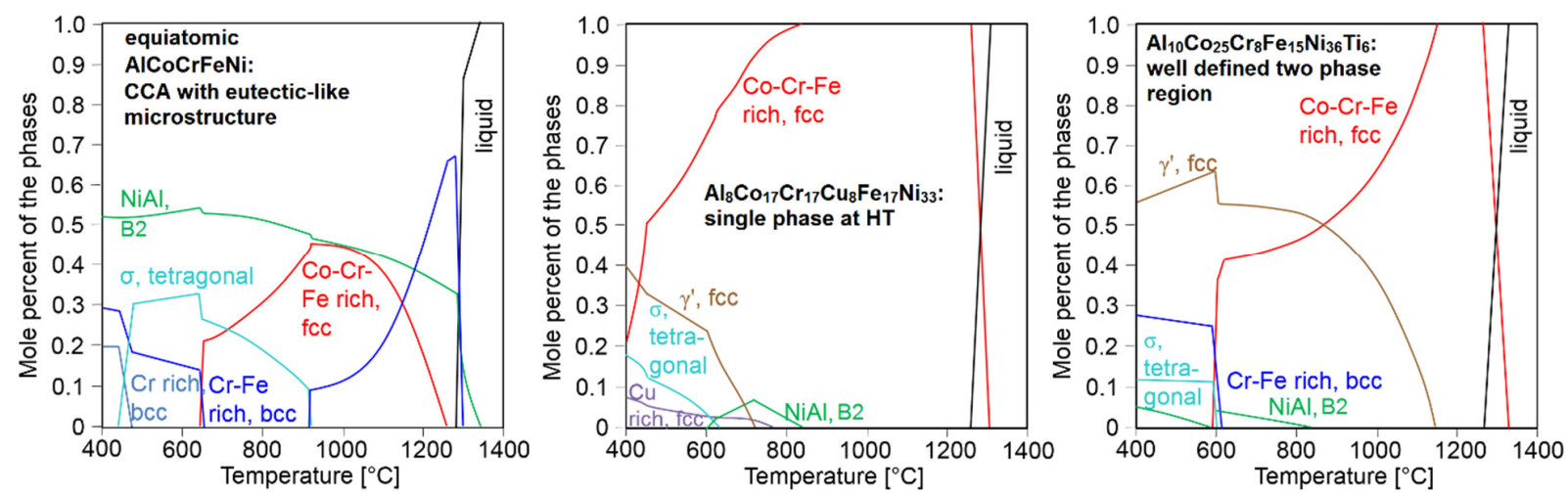

Figure 1: Three examples of CALPHAD phase predictions at conditions near equilibrium: (a) equiatomic $\mathrm{AlCoCrFeNi}$; (b) $\mathrm{Al}_{8} \mathrm{Co}_{17} \mathrm{Cr}_{17} \mathrm{Cu}_{8} \mathrm{Fe}_{17} \mathrm{Ni}_{33}$ (in at.\%), a CCA with a single-phase region in-between $800^{\circ} \mathrm{C}$ and $1250^{\circ} \mathrm{C}$; (c) $\mathrm{Al}_{10} \mathrm{Co}_{25} \mathrm{Cr}_{8} \mathrm{Fe}_{15} \mathrm{Ni}_{36} \mathrm{Ti}_{6}$ (in at.\%), a CCA with a well-defined two-phase region, adapted from [28-30].

The first example shows an alloy that solidifies - if we compare it with binary alloys - via a eutectic transformation. Three phases (liquid, $\mathrm{NiAl}$ and a $\mathrm{Cr}-\mathrm{Fe}$ rich phase) are in equilibrium at $\sim 1300^{\circ} \mathrm{C}$. The casting process gives rise to the NiAl phase of $\mathrm{B} 2$ structure, shown in green, and the $\mathrm{Cr}-\mathrm{Fe}$ rich phase of $\mathrm{A} 2$ structure, shown in dark blue (see [31]). Depending on the heat treatment, the Co-Cr rich phase of A1 structure can form at high temperature [32, 33].

The second example shows a CCA which has a single phase window at high temperature $\left(800^{\circ} \mathrm{C}-\mathrm{T}_{\mathrm{s}}, \mathrm{T}_{\mathrm{s}}=\right.$ $1260^{\circ} \mathrm{C}=$ solidus temperature), which can be quenched-in. Such an alloy could be used well for studying the formation temperature of the phases that are predicted to be stable at temperatures below $800^{\circ} \mathrm{C}$. 
The third example shows an alloy with a homogenization window at high temperature and a two-phase region of $\gamma^{\prime}$ phase in equilibrium with an fcc phase over a temperature range of $600^{\circ} \mathrm{C}-1120^{\circ} \mathrm{C}$. Taking the comment above into consideration, the lower temperature limit might not be existent, since the kinetics will be too slow for the predicted transition from fcc to bcc.

\subsubsection{The mechanical approach}

Lately, several methods such as thermo-mechanical treatments, friction stir processing, severe plastic deformation by several means, etc. have been used to refine the microstructures and improve the mechanical properties of both HEA and CCA [13-15, 34]. The grain refinement introduces grain boundaries as obstacles for moving dislocations, which increases strength and hardness. This relative hardening increase is independent on the composition as the refinement is given by the Hall-Petch relation [35, 36], with:

$\sigma_{\mathrm{y}}=\sigma_{0}+\frac{\mathrm{K}}{\sqrt{\mathrm{d}}}$

Equation 1

with the yield strength (YS) as $\sigma_{y}, \sigma_{0}$ the yield strength of a sample with large gain size, the grain boundary strength $\mathrm{K}$ and the grain size $\mathrm{d}$. Please note that this relation is valid at lower temperatures only $(\mathrm{T}<0.4 \times$ $T_{s}$, with the solidus temperature $T_{s}$ of the alloy). One example of grain refinement in the CoCrFeMnNi HEA is given in the work by Sun et al. [37] (see Figure 2).
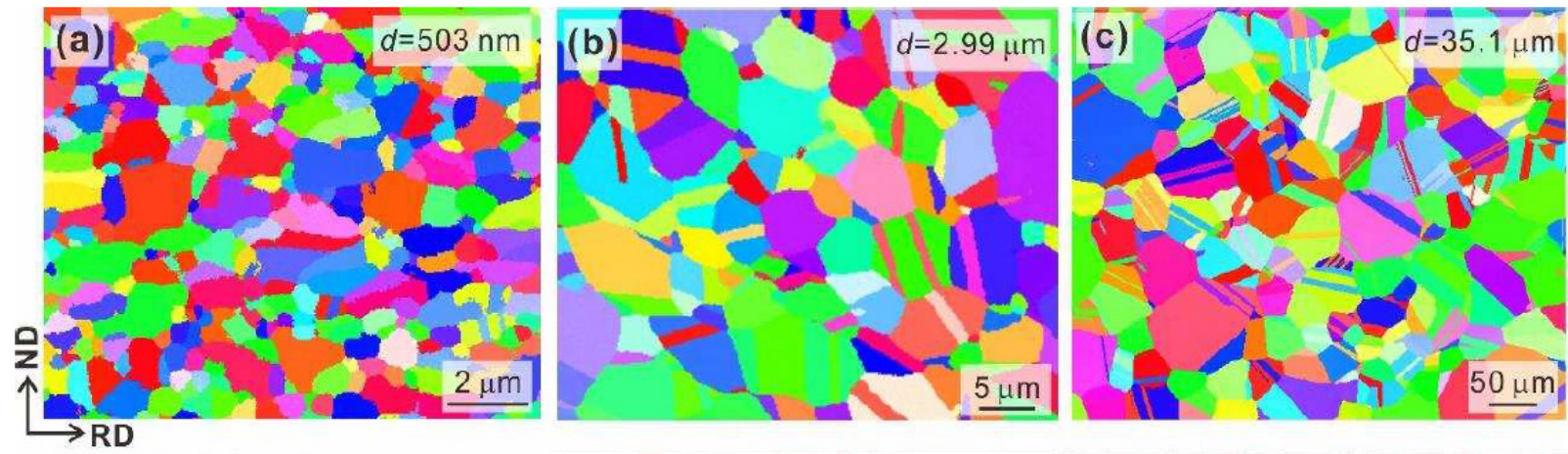

Figure 2: EBSD images of the CoCrFeMnNi alloy, solution treated at $1100{ }^{\circ} \mathrm{C}$ for $2 \mathrm{~h}$, hot forged at $1000{ }^{\circ} \mathrm{C}$, cold rolled and (a) $650{ }^{\circ} \mathrm{C}$ for 30 minutes, (b) $900{ }^{\circ} \mathrm{C}$ for 30 minutes and (c) $1100{ }^{\circ} \mathrm{C}$ for 30 minutes. Reprinted from Mat. Sci. Eng. A - Structural Materials Properties Microstructure and Processing, 712, S.J. Sun, Y.Z. Tian, H.R. Lin, H.J. Yang, X.G. Dong, Y.H. Wang, Z.F. Zhang Transition of twinning behavior in CoCrFeMnNi high entropy alloy with grain refinement, pages 603-607, Copyright (2018), with permission from Elsevier.

The grains are characterized by the authors with an average grain size of $500 \mathrm{~nm}$ solution treated at 1100 ${ }^{\circ} \mathrm{C}$ for $2 \mathrm{~h}$, hot forged at $1000{ }^{\circ} \mathrm{C}$, cold rolled and finally heat treatment of $650{ }^{\circ} \mathrm{C}$ for 30 minutes, and of 35 $\mu \mathrm{m}$ after the same procedure except for a final heat treatment of $1100^{\circ} \mathrm{C}$. As can be seen in Figure 2, the growth in grain size is accompanied by a twinning behaviour, as well as by a decrease in yield strength and an increase in ductility.

\subsubsection{Combining both methods}

Many works use a combination of the two methods, i.e. compositional change and thermomechanical treatment for an optimum in mechanical properties. The work by Cheng et al. compared the single phase equiatomic $\mathrm{CoCrFeMnNi} \mathrm{HEA} \mathrm{to} \mathrm{a} \mathrm{Co}_{20} \mathrm{Cr}_{20} \mathrm{Fe}_{20} \mathrm{Mn}_{20} \mathrm{Ni}_{20} \mathrm{C}_{2} \mathrm{CCA}$ [38] after a complex thermomechanical treatment, see 3.3.3D. Even though they use this systematic approach, a concluding comparison of the four alloys was no possible, because the average grain size in the forged - homogenized state on the one hand and the cold-rolled - annealed state on the other hand was not the same. Another example of the combination 
of the two methods can be found in the work by Gwalani et al. [39] (see section 3.3.1b). The alloy $\mathrm{Al}_{7} \mathrm{Co}_{23} \mathrm{Cr}_{23} \mathrm{Fe}_{23} \mathrm{Ni}_{23}$ is cold-rolled and subsequently recrystallized to different grain sizes. Hardness results correlate well with the Hall-Petch relation, equation 1. However, the short heat treatments after the coldrolling does not guarantee an equilibrium condition of the alloy, and thus the remaining deformation (strengthening by work hardening) plays an important additional role in the strengthening, overlapping with the grain boundary strengthening.

To our knowledge, there is only one group that has compared a single-phase HEA with a comparable CCA for the same grain sizes, at a non-equilibrium state [39]. In that work, the additional $\mathrm{L}_{2}$ and/or B2 phase increases the ultimate tensile strength. It is supposed that this would also be the case in other CCAs, but due to lack of data no general conclusion can be drawn.

Because of the difficulty of separating the effects, the thermomechanical approach will only play a minor role in this review and the focus will be on near equilibrium states in order to more clearly compare the influence of alloy composition. Therefore, we will focus on the two strengthening mechanisms mainly controlled by composition: solid solution and precipitate strengthening.

After an optimized composition (and if necessary an optimized heat treatment, is established, additional strengthening mechanism can be used, such as grain boundary strengthening, work hardening and dispersion hardening. As has already been mentioned, the remaining strengthening mechanism, transformation induced strengthening, playing an important role for steels going into direction of CCA and HEA Is not very common yet and will be presented in section 3.3.1.

\section{General overview over this manuscript}

This manuscript focuses on younger articles that describe alloys with a certain application in mind. The preferred benchmark is a tensile test and the data used for comparison is engineering stress and strain, unless otherwise stated. However, as articles based on tensile tests on HEA and CCA are quite rare, works based on compression, hardness or creep tests are being considered.

Preference is given to alloys that are homogenized in the sense that the dendritic structure has been checked, and to articles, which do not only use SEM and XRD but also high magnification techniques such as TEM or atom probe tomography. This method allows a clearer distinction between HEA and CCA, which is one of the main focus points of this manuscript - sometimes smaller phases can remain undetected when the characterization method is not precise enough, even though they may have a great influence. In that case conclusions on the mechanical behaviour, based on the microstructure, can be faulty.

Throughout the manuscript, two notations will be used for the alloys, i.e. the equiatomic notation (e.g. $\mathrm{CoCrFeMnNi}$, corresponding to 20 at.\% for each element in a 5-component alloy) and the atomic percentage notation (e.g. $\mathrm{Co}_{20} \mathrm{Cr}_{20} \mathrm{Fe}_{20} \mathrm{Mn}_{20} \mathrm{Ni}_{20}$ ).

Considering all these aspects, we started with quite strict criteria for the compared CCA in the present article. These criteria are by no means exclusive, restrictive or exhaustive in the world of CCA, but merely represent a measure for choosing literature studies for this review. The criteria are listed in Table 2. 
1 The alloys must meet the definition of CCA, see Table 1. Most important are the composition (no element more than 35 at. \%) and the number of elements (at least five different elements).

2 Alloys must be cast, not mechanically alloyed. The process of mechanical alloying usually introduces a high number of porosities, carbides, or nitrides, which makes an understanding of the base materials very challenging.

3 Investigations in the cited article must be such that the reader can be sure that every phase in the alloy has been detected. An investigation with only SEM and XRD is often not precise enough to detect nanoscale precipitates (for an example see [29]: the $15 \mathrm{~nm}$ scaled $\gamma^{\prime}$ precipitates were not detected in the XRD but only in the TEM).

4 The alloys must be homogenized at a high enough temperature and for a long enough time to relieve dendritic segregations and possibly internal stresses, which have been developed during solidification.

5 Cooling conditions and heat treatment conditions must be stated. This step is necessary for the reproducibility of the results. Subsequently to the homogenization, a second heat treatment can promote the formation of desired phases. In general, it must be ensured that the alloy is close to its equilibrium.

6 There must be an application aim of the investigated alloy and an increase or decrease of a property that can be clearly linked to the alloy composition and/or phase morphology.

7 If an application with good mechanical properties is anticipated, the investigation must be made by the more sophisticated tensile (creep) tests and not by compression testing.

8 If precipitation strengthening is the anticipated strengthening mechanism, it is essential to know important characteristics of the strengthening phase, i.e. composition, crystallographic structure, size, volume fraction, distribution and shape of the precipitates.

Table 2: Criteria that serve for comparing the investigated CCA

Comment to 7: Several papers have been published recently [14, 39-41] which use a thermomechanical method for grain refinement as a strengthening method. Sometimes this process includes the formation of a phase at the grain boundaries. Since this phase influence can usually not be separated from the influence of the finer grains, special care should be put on conclusions of which phenomenon (grain refinement or second phase) provides which amount of contribution to strengthen the material.

In order to give an example of how problematic the as-cast state and the lack of high resolution investigation methods can be, an overview is given over the detected states in one of the most intensely investigated CCA: the equiatomic alloy AlCoCrCuFeNi (Table 3).

\begin{tabular}{ccc}
\hline Phases detected & Methods used & Reference \\
\hline bcc, fcc1, fcc2 2 & XRD, SEM-EDS & {$[42]$} \\
bcc, fcc 1, fcc2, B2, orthorhombic, & XRD, SEM, TEM & {$[43]$} \\
Simple bcc + fcc & XRD & {$[44]$} \\
Mainly bcc and some fcc & XRD & {$[45]$} \\
bcc, B2, $\mathrm{L} 11_{2}-1, \mathrm{~L} 1_{2}-2$ & XRD, SEM, TEM & {$[46]$} \\
bcc, fcc, B2-1, B2-2, $\mathrm{L} 1_{2}-1, \mathrm{~L} 1_{2}-2$ & XRD, SEM, TEM-EDS, APT & {$[47]$} \\
\hline
\end{tabular}

Table 3: Detected phases in the equiatomic as-cast alloy AlCoCrCuFeNi.

While reading the literature we realized that there is hardly any investigation that meets all eight criteria. We thus decided to gather investigations that do meet most of the criteria. 
Up to now, there is no information available if a CCA performs better than an HEA when it comes to oxidation. Even though this is a highly interesting subject, we will not go into this detail within this review, due to the lack of data.

\section{Different types of CCA}

\section{1 "Accidental CCA" / general interest}

This family of CCA is probably the largest one with the most potential, because there is much room for optimization. Many CCA have been determined and classified but they have not been developed further to meet a specific use. This leads to an enormous database with many promising alloys. A few of them will be presented here, but as they do not meet the eight aforementioned criteria, they are not treated in detail in this manuscript.

\subsubsection{Undetected phases: "HEA" which are CCA}

A special group of CCA is the one that seems to be an HEA if the investigation methods used are not precise enough. These would be a "hidden" CCA. One example is given in the work by Wang et al. [48]. The second $\mathrm{Cu}$ rich phase in the equiatomic $\mathrm{CoCrCuFeNi}$ alloy is not recognized by XRD measurements but is clearly visible in the SEM image.

\subsubsection{General interest: exploring the phase diagrams}

\section{- Changing the content of one element}

Several papers investigate the influence of one alloying element. Two examples are given below:

a) Example Mo [49]: $\mathrm{Al}_{\mathrm{y}} \mathrm{Cr}_{\mathrm{y}} \mathrm{Fe}_{\mathrm{y}} \mathrm{Ni}_{\mathrm{y}} \mathrm{Mo}_{\mathrm{x}}$, with $\mathrm{x}$ from 0 to 25 and $\mathrm{y}=(100-\mathrm{x}) / 4$

When $\mathrm{Mo}$ is added to the $\mathrm{Al}_{\mathrm{y}} \mathrm{Cr}_{\mathrm{y}} \mathrm{Fe}_{\mathrm{y}} \mathrm{Ni}_{\mathrm{y}} \mathrm{Mo}_{\mathrm{x}}$ alloy, with $\mathrm{x}$ from 0 to 25 and $\mathrm{y}=(100-\mathrm{x}) / 4$, the lamellar morphology changes to roundish shapes. At Mo contents higher than 0.05 at. $\%$ the $\sigma$ phase appears. This work gives valuable information on the influence of Mo, but, unfortunately, there is neither a homogenization, nor a high precision characterization technique that could make a link between the microstructure and the compressive properties.

b) Example W [50]:

Addition of $\mathrm{W}$ of up to 20 at.\% to the two alloys $\mathrm{Cr}_{22} \mathrm{Fe}_{22} \mathrm{Ni}_{44} \mathrm{~V}_{11} \mathrm{Cr}_{2 \mathrm{x}} \mathrm{Fe}_{2 \mathrm{x}} \mathrm{Ni}_{4 \mathrm{x}} \mathrm{V}_{\mathrm{x}} \mathrm{W}_{\mathrm{y}}$ (with $\mathrm{x}$ from 9 to 11 and $\mathrm{y}=100-9 \mathrm{x}$ ) and the $\mathrm{Cr}_{2 \mathrm{x}} \mathrm{Fe}_{2 \mathrm{x}} \mathrm{Ni}_{2 \mathrm{x}} \mathrm{V}_{\mathrm{x}} \mathrm{W}_{\mathrm{y}}$ (with $\mathrm{x}$ from 11 to 14 and $\mathrm{y}=100-7 \mathrm{x}$ ) alloys enhances their strength while maintaining a good ductility. However, the absence of a thorough homogenization and controlled annealing procedure, combined with only SEM and XRD characterization makes it difficult to understand the mechanisms that improve the properties when $\mathrm{W}$ is added to these two alloys. At least three phases, i.e. fcc, bcc and $\sigma$ have been detected in all of the above mentioned $\mathrm{W}$ containing alloys.

\section{- Changing the heat treatment}

One example for the investigation of the influence of the heat treatment is given in [51, 52]:The $\mathrm{Al}_{11} \mathrm{Co}_{22} \mathrm{Cr}_{22} \mathrm{Fe}_{22} \mathrm{Ni}_{22}$ alloy, has been heat treated at $650^{\circ} \mathrm{C}$ for short times at 0.5 and $8 \mathrm{~h} \mathrm{[51]}$, at temperatures in-between $450-1150^{\circ} \mathrm{C}$ [52]. A decrease in elongation to fracture $\varepsilon_{\mathrm{f}}$ and an increase of both the ultimate tensile strength UTS and the yield strength YS is observed when the annealing time increases. However, the tensile data of the as-cast alloy shows some scatter, probably due to the lack of homogenization. Thus, it is difficult to understand the phase influence. 


\subsection{Industrial approach: production of larger quantities, stability over some composition range}

The industrial approach is characterized by the need for a higher tolerance towards variations in composition and for the fabrication of larger quantities of material (here $\sim 2.5 \mathrm{~kg}$ ). The development of these testing methods usually does not include any high-precision measuring methods like TEM or APT, but the need for this approach is unquestionable in view of future applications. Up to now, there is only one article that focuses on up-scaling of $\mathrm{Al}_{18} \mathrm{Cr}_{18} \mathrm{Fe}_{18} \mathrm{Ni}_{36} \mathrm{Ti}_{9}$ [53].

\subsection{CCA with specific properties}

Most research on CCA deals with the improvement of mechanical properties. Other important properties are oxidation, electric, magnetic, and corrosion properties. There is little to no research on how these properties are influenced by the fact that there is more than one phase engaged, as is in our definition of CCA, compared to single phase.

The most investigated of these four properties is oxidation. However, even for this property, there is little research on how CCA provide a better oxidation resistance than HEA. The improvement in oxidation is usually linked to a higher content of specific protective elements like $\mathrm{Al}$ or $\mathrm{Cr}$, but not to the fact that there are more phases in the alloy. Fe usually reduces the oxidation resistance.

One of the rare papers that investigate local oxide formation is given by Gorr et al. [54], in which the authors investigate an equiatomic AlCrMoTiW alloy. It was not homogenized. Previous research shows that the ascast AlCrMoTiW consists of at least two phases [55].The authors could detect a preferential protective oxide layer formation in regions with less Mo and W.

\subsubsection{Two-phase alloys}

\section{a) TRIP-assisted dual phase $\mathrm{CCA}-\mathrm{Co}_{\mathrm{v}} \mathrm{Cr}_{\mathrm{w}} \mathrm{Fe}_{\mathrm{x}} \mathrm{Mn}_{\mathrm{y}} \mathrm{Ni}_{\mathrm{z}}$}

These works have a unique approach to the formation of CCA alloys [16-18, 34]. The authors encourage the formation of hep grains from fcc grains in order to form a metastable transformation induced plasticity (TRIP) dual-phase alloy, a method that is known from steels. To our knowledge, these are the only groups working on the aforementioned transformation hardening method (see 1.2). The percentage of hcp grains increases with the increasing deformation, by increasing the annealing time [18] and/or by increasing the amount of Mn [17]. Best tensile results are obtained for those specimens which are furthest away from the equilibrium, i.e. least recrystallized after deformation ( 3 min recrystallization time) or most friction stirred (350 rounds per minute) before crossing the critical point of too much deformation $(650 \mathrm{rpm})$. When available, both engineering and true tensile data of this group of CCA are listed in Table 4. This table shows the importance of the difference between these two modes. 


\begin{tabular}{|c|c|c|c|c|c|c|c|c|c|c|}
\hline \multirow[t]{2}{*}{ Alloy } & \multirow{2}{*}{$\begin{array}{l}\text { Specimen } \\
\text { state }\end{array}$} & \multirow{2}{*}{$\begin{array}{c}\text { Vol. } \\
\% \\
\text { hcp } \\
{[\%]} \\
\end{array}$} & \multirow{2}{*}{$\begin{array}{c}\text { Avg. } \\
\text { grain } \\
\text { size } \\
{[\mu \mathrm{m}]} \\
\end{array}$} & \multicolumn{3}{|c|}{ Engineering data } & \multicolumn{3}{|c|}{ True data } & \multirow[t]{2}{*}{ Ref. } \\
\hline & & & & $\begin{array}{c}\mathcal{E}_{\mathrm{f}} \\
{[\%]}\end{array}$ & $\begin{array}{c}\text { YS } \\
{[\mathrm{MPa}]}\end{array}$ & $\begin{array}{c}\text { UTS } \\
{[\mathrm{MPa}]}\end{array}$ & $\begin{array}{c}\varepsilon_{\mathrm{f}} \\
{[\%]}\end{array}$ & $\begin{array}{c}\text { YS } \\
{[\mathbf{M P a}]}\end{array}$ & $\begin{array}{c}\text { UTS } \\
{[\mathrm{MPa}]}\end{array}$ & \\
\hline $\mathrm{CoCrFeMnNi}$ & $\begin{array}{c}1200^{\circ} \mathrm{C} 48 \mathrm{~h}- \\
\text { cold rolling - } \\
800^{\circ} \mathrm{C} 1 \mathrm{~h}\end{array}$ & - & 4.4 & $\sim 56$ & $\sim 370$ & $\sim 670$ & 42 & $\sim 315$ & $\sim 935$ & [8] \\
\hline $\mathrm{Co}_{10} \mathrm{Cr}_{10} \mathrm{Fe}_{50} \mathrm{Mn}_{30}$ & $1200^{\circ} \mathrm{C} 2 \mathrm{~h}$ & 28 & 45 & 50 & 250 & 730 & 40 & $\sim 260$ & $\sim 1120$ & [18] \\
\hline $\mathrm{Co}_{10} \mathrm{Cr}_{10} \mathrm{Fe}_{50} \mathrm{Mn}_{30}$ & $\begin{array}{l}1200^{\circ} \mathrm{C} 2 \mathrm{~h}- \\
\text { cold rolling - } \\
900^{\circ} \mathrm{C} 3 \mathrm{~min}\end{array}$ & 32 & 4.5 & 75 & $\sim 330$ & 870 & 50 & $\sim 315$ & $\sim 1380$ & [18] \\
\hline $\mathrm{Co}_{10} \mathrm{Cr}_{10} \mathrm{Fe}_{50} \mathrm{Mn}_{30}$ & $\begin{array}{l}1200^{\circ} \mathrm{C} 2 \mathrm{~h}- \\
\text { cold rolling }- \\
900^{\circ} \mathrm{C} 5 \mathrm{~min}\end{array}$ & 14 & 6 & $\sim 65$ & $\sim 280$ & $\sim 800$ & 46 & $\sim 280$ & $\sim 1260$ & [18] \\
\hline $\mathrm{Co}_{10} \mathrm{Cr}_{10} \mathrm{Fe}_{50} \mathrm{Mn}_{30}$ & $\begin{array}{l}1200^{\circ} \mathrm{C} / 2 \mathrm{~h}- \\
\text { cold rolling - } \\
900^{\circ} \mathrm{C} 30 \mathrm{~min}\end{array}$ & 31 & 15 & 63 & 350 & 830 & 45 & $\sim 280$ & $\sim 1255$ & [18] \\
\hline $\mathrm{Co}_{10} \mathrm{Cr}_{10} \mathrm{Fe}_{50} \mathrm{Mn}_{30}$ & $\begin{array}{l}\text { hot rolling - } \\
1200^{\circ} \mathrm{C} 5 \mathrm{~h}- \\
\text { friction stirred } \\
350 \mathrm{rpm}\end{array}$ & 10 & 6.5 & & & & 45 & 298 & $\sim 1400$ & [34] \\
\hline $\mathrm{Co}_{10} \mathrm{Cr}_{10} \mathrm{Fe}_{50} \mathrm{Mn}_{30}$ & $\begin{array}{l}\text { hot rolling - } \\
1200^{\circ} \mathrm{C} 5 \mathrm{~h}- \\
\text { friction stirred } \\
650 \mathrm{rpm}\end{array}$ & 8 & 5.2 & & & & 42 & 400 & $\sim 1200$ & [34] \\
\hline
\end{tabular}

Table 4: Tensile engineering and true data of the different states of the equiatomic CoCrFeMnNi and the

$\mathrm{Co}_{10} \mathrm{Cr}_{10} \mathrm{Fe}_{50} \mathrm{Mn}_{30}$ alloy. Rpm: rounds per minute.

This alloying method is based on the martensitic transformation of the fcc phase into the hcp phase upon cooling from the high temperature fcc phase. The fcc structured phase which has a decreased stacking fault energy [56], undergoes a deformation induced displacive transformation, which then leads to the hcp structured phase. The partial martensitic transformation during quenching leads to a special CCA with two differently structured phases of identical chemical composition [16-18, 34].

Unfortunately, the alloy compositions does not fulfil the composition criterion (Criterion 1), but the approach is unique and very remarkable.

\section{b) The $\mathrm{Al}_{7} \mathrm{Co}_{23} \mathrm{Cr}_{23} \mathrm{Fe}_{23} \underline{N i}_{23}$ alloy: an fcc alloy with different second phases}

This alloy is the focus of many investigations and the literature data provides very different result on the nature of this alloy [40, 57-60]. The chemical composition of $\mathrm{Al}_{7} \mathrm{Co}_{23} \mathrm{Cr}_{23} \mathrm{Fe}_{23} \mathrm{Ni}_{23}$ alloy is located near the phase boundary between fcc and bcc. It is generally agreed that the highest volume fraction phase is fcc, but it can be accompanied by $\mathrm{L}_{2}$ or $\mathrm{B} 2$ structured phases, depending on heat treatment. Table 5 gives an overview over the different results. Because of the complexity of this alloy, it will be covered in this extra section. 


\begin{tabular}{|c|c|c|c|}
\hline Specimen state & Phases & Ref. & Methods \\
\hline $1000^{\circ} \mathrm{C} 48 \mathrm{~h}$ slow cooling, subsequent cold-rolling & fcc grains, bcc at GB & [60] & $\begin{array}{l}\text { SEM + EBSD } \\
\quad+\text { TEM }\end{array}$ \\
\hline $\begin{array}{c}\text { cold rolled by } 20 \% \text { and solutionized at } 1200^{\circ} \mathrm{C} 1 / 2 \mathrm{~h} \\
\text { followed by water quenching }\end{array}$ & fcc & [40] & TEM \\
\hline $\begin{array}{c}\text { cold rolled by } 20 \% \text { and solutionized at } 1200^{\circ} \mathrm{C} 1 / 2 \mathrm{~h} \\
\text { followed by water quenching - annealing } 550^{\circ} \mathrm{C} 150 \mathrm{~h} \\
- \text { - quenched }\end{array}$ & $\mathrm{fcc}+\mathrm{L} 1_{2}$ & [40] & TEM \\
\hline $\begin{array}{l}\text { cold rolled by } 20 \% \text { and solutionized at } 1200^{\circ} \mathrm{C} 1 / 2 \mathrm{~h} \\
\text { followed by water quenching - annealing } 700^{\circ} \mathrm{C} 50 \mathrm{~h}\end{array}$ & $\mathrm{fcc}+\mathrm{L} 1_{2}$ & [40] & TEM \\
\hline cold-rolling $-1150^{\circ} \mathrm{C} 1 \mathrm{~h}$ & fcc & [39] & TEM \\
\hline cold-rolling $-1150^{\circ} \mathrm{C} 1 \mathrm{~h}-700^{\circ} 50 \mathrm{~h}$ & $\mathrm{fcc}+\mathrm{B} 2$ & [39] & TEM \\
\hline cold-rolling $-1150^{\circ} \mathrm{C} 1 \mathrm{~h}-550^{\circ} 150 \mathrm{~h}$ & $\mathrm{fcc}+\mathrm{L} 12$ & [39] & TEM \\
\hline cold-rolling $-1150^{\circ} \mathrm{C} 2 \mathrm{~min}$ & fcc & [39] & TEM \\
\hline cold-rolling $-1150^{\circ} \mathrm{C} 2 \mathrm{~min}-620^{\circ} \mathrm{C} 50 \mathrm{~h}$ & fcc, $\mathrm{L1}_{2}, \mathrm{~B} 2$ & [39] & TEM \\
\hline As-cast & fcc & [57] & SEM + XRD \\
\hline $\begin{array}{c}1100^{\circ} \mathrm{C} 24 \mathrm{~h} \text { followed by water quenching (Note: } 0.25 \\
\text { or } 0.375 \text { ) }\end{array}$ & $\mathrm{fcc}+$ maybe bcc & [57] & $\mathrm{SEM}+\mathrm{XRD}$ \\
\hline $1250^{\circ} \mathrm{C} 50 \mathrm{~h}$, furnace cooling & fcc $(+b c c)$ & [61] & $\mathrm{XRD}+\mathrm{EBSD}$ \\
\hline As-cast & $\mathrm{fcc}+\mathrm{L} 1_{2}$ & [62] & TEM \\
\hline Aged at $700^{\circ} \mathrm{C} 72 \mathrm{~h}$, quenched & $\mathrm{fcc}+\mathrm{L} 1_{2}$ & [62] & TEM \\
\hline Aged at $900^{\circ} \mathrm{C} 72 \mathrm{~h}$, quenched & $\mathrm{fcc}+\mathrm{B} 2$ & [62] & TEM \\
\hline Aged at $900^{\circ} \mathrm{C} 2 \mathrm{~h}$ & fcc & [63] & $\mathrm{SEM}+\mathrm{XRD}$ \\
\hline Aged at $1100^{\circ} \mathrm{C} 2 \mathrm{~h}$ & fcc & [63] & $\mathrm{SEM}+\mathrm{XRD}$ \\
\hline Aged at $850^{\circ} \mathrm{C} 1 \mathrm{~h}$ & $\mathrm{fcc}+\mathrm{B} 2$ & [64] & TEM \\
\hline
\end{tabular}

Table 5: Information about $\mathrm{Al}_{7} \mathrm{Co}_{23} \mathrm{Cr}_{23} \mathrm{Fe}_{23} \mathrm{Ni}_{23}$ from various works

The work of Yasuda et al. [60] uses the method of grain refinement in the $\mathrm{Al}_{7} \mathrm{Co}_{23} \mathrm{Cr}_{23} \mathrm{Fe}_{23} \mathrm{Ni}_{23}$ alloy. It focuses on the precipitation of the $\mathrm{B} 2$-type NiAl phase, which precipitates at the grain boundaries after a thermomechanical heat treatment. A polycrystalline sample is then compared with a single crystal sample with the same alloy composition $\mathrm{Al}_{7} \mathrm{Co}_{23} \mathrm{Cr}_{23} \mathrm{Fe}_{23} \mathrm{Ni}_{23}$.

The polycrystalline samples were homogenized at $1100^{\circ} \mathrm{C} 48 \mathrm{~h}$, cold rolled and then recrystallized at 800$1000^{\circ} \mathrm{C} 1 \mathrm{~h}$. The specimens were investigated by SEM, EBSD, TEM and EDS. Single crystals were prepared by the floating zone method [65]. The B2 precipitates seem to suppress the grain growth during the recrystallization of the alloy following cold rolling, which then results in an ultrafine-grained microstructure. Table 6 summarizes the observations. No precipitates were detected in the single crystals. Tensile data is summarized in Table 6.

\begin{tabular}{ccccccc}
\hline & Phases & $\begin{array}{c}\text { Avg. grain } \\
\text { size }[\boldsymbol{\mu m}]\end{array}$ & $\begin{array}{c}\boldsymbol{\varepsilon}_{\mathrm{f}} \\
{[\%]}\end{array}$ & $\begin{array}{c}\text { YS } \\
{[\mathbf{M P a}]}\end{array}$ & $\begin{array}{c}\text { UTS } \\
{[\mathbf{M P a}]}\end{array}$ & Ref. \\
\hline $1100^{\circ} \mathrm{C} 48 \mathrm{~h}-$ cold-rolling $-800^{\circ} \mathrm{C} 1 \mathrm{~h}$ & $\mathrm{fcc}+\mathrm{B} 2$ & 0.7 & $\sim 48$ & $\sim 860$ & $\sim 1050$ & {$[60]$} \\
$1100^{\circ} \mathrm{C} 48 \mathrm{~h}-$ cold-rolling $-900^{\circ} \mathrm{C} 1 \mathrm{~h}$ & $\mathrm{fcc}+\mathrm{B} 2$ & 2.7 & $\sim 51$ & $\sim 690$ & $\sim 930$ & {$[60]$} \\
$1100^{\circ} \mathrm{C} 48 \mathrm{~h}-$ cold-rolling $-1000^{\circ} \mathrm{C} 1 \mathrm{~h}$ & $\mathrm{fcc}+\mathrm{B} 2$ & 3.8 & $\sim 64$ & $\sim 550$ & $\sim 800$ & {$[60]$} \\
$1100^{\circ} \mathrm{C} 48 \mathrm{~h}-$ cold-rolling $-1100^{\circ} \mathrm{C} 1 \mathrm{~h}$ & $\mathrm{fcc}$ & 53 & $\sim 87$ & $\sim 260$ & $\sim 620$ & {$[60]$} \\
\hline
\end{tabular}

Table 6: Tensile data at room temperature of the cold rolled and recrystallized $\mathrm{Al}_{7} \mathrm{Co}_{23} \mathrm{Cr}_{23} \mathrm{Fe}_{23} \mathrm{Ni}_{23}$ alloy, by Yasuda at al. [60] 
The authors conclude that the grain boundary strengthening is mainly responsible for the high strength of the recrystallized $\mathrm{Al}_{7} \mathrm{Co}_{23} \mathrm{Cr}_{23} \mathrm{Fe}_{23} \mathrm{Ni}_{23}$ samples. However, the effect of the B2-type precipitates on the strength seems to be small. The authors explain this effect by the NiAl precipitates along the grain boundaries being coarse and the intragranular precipitates' dissolving. The B2 phase has thus not a direct effect on strength, but only an indirect one by ensuring the existence of small grains over a large temperature range.

Another study on the Hall-Petch strengthening in the $\mathrm{Al}_{7} \mathrm{Co}_{23} \mathrm{Cr}_{23} \mathrm{Fe}_{23} \mathrm{Ni}_{23}$ alloy was carried out by Gwalani et al. [39]. Additionally, they investigated precipitation strengthening due to two different types of ordered precipitates, i.e. $\mathrm{L}_{2}$ and $\mathrm{B} 2[39,40]$ and they make remarkable efforts in attributing the alloy strengthening to one mechanism or the other. The influence of the grain size is the focus of [39], and it implies quite complex heat treatments for the alloy. The mechanical data is linked to the grain size by equation (1).

As this review focuses on the influence of second or third phases, we will compare only those alloys with the same average grain size of about $144 \mu \mathrm{m}$ on the one hand and those of $23 \mu \mathrm{m}$ on the other hand, and different heat treatments which lead to different phases [40]. The cold-rolled samples were first homogenized at $1150^{\circ} \mathrm{C}$ and then annealed at 550,620 and $700^{\circ} \mathrm{C}$. According to XRD and/or TEM results, this leads to the formation of $\mathrm{B} 2$ and/or $\mathrm{L} 1_{2}$ precipitates. It is important to note that the $\mathrm{B} 2$ precipitates mostly localize at the grain boundaries while the $\mathrm{L}_{2}$ precipitates nucleate inside the grains. The homogenized states and the annealed states have been submitted to tensile tests. The results are summarized in Table 7.

\begin{tabular}{|c|c|c|c|c|c|}
\hline Specimen state & Grain size & Phases & $\begin{array}{c}\varepsilon_{\mathrm{f}} \\
{[\%]}\end{array}$ & $\begin{array}{c}\text { YS } \\
{[\mathrm{MPa}]}\end{array}$ & $\begin{array}{c}\text { UTS } \\
\text { [MPa] }\end{array}$ \\
\hline cold-rolling $-1150^{\circ} \mathrm{C} 1 \mathrm{~h}$ & 144 & fcc & 65 & 159 & 410 \\
\hline cold-rolling $-1150^{\circ} \mathrm{C} 1 \mathrm{~h}-700^{\circ} 50 \mathrm{~h}$ & 144 & $\mathrm{fcc}+\mathrm{B} 2$ & 43 & 215 & 520 \\
\hline cold-rolling $-1150^{\circ} \mathrm{C} 1 \mathrm{~h}-550^{\circ} 150 \mathrm{~h}$ & 144 & $\mathrm{fcc}+\mathrm{L} 12$ & 55 & 285 & 540 \\
\hline cold-rolling $-1150^{\circ} \mathrm{C} 2 \mathrm{~min}$ & 23 & fcc & 60 & 263 & 589 \\
\hline cold-rolling $-1150^{\circ} \mathrm{C} 2 \mathrm{~min}-620^{\circ} \mathrm{C} 50 \mathrm{~h}$ & 23 & fcc, $\mathrm{L1}_{2}, \mathrm{~B} 2$ & 45 & 490 & 840 \\
\hline
\end{tabular}

Table 7: Tensile data of the $\mathrm{Al}_{7} \mathrm{Co}_{23} \mathrm{Cr}_{23} \mathrm{Fe}_{23} \mathrm{Ni}_{23}$ alloy with and without $\mathrm{B} 2$ and $\mathrm{L}_{2}$ precipitates [39].

The authors provide a calculation for the influence of the $\mathrm{B} 2$ and $\mathrm{L}_{2}$ precipitates on the yield strength, additionally to the grain size dependent Hall-Petch effect (equation (2)):

$\sigma_{y}=\sigma_{0}+\frac{K}{\sqrt{d}}+\Delta \sigma_{L 12}+\Delta \sigma_{B 2}$

Equation 2

Additionally to the parameters already explained in equation (1), $\Delta \sigma_{\mathrm{L} 12}$ and $\Delta \sigma_{\mathrm{B} 2}$ correspond to the increase in yield strength, resulting from the $\mathrm{L}_{2}$ and $\mathrm{B} 2$ precipitates, respectively. The values of $\Delta \sigma_{\mathrm{L} 12}=126 \mathrm{MPa}$ and $\Delta \sigma_{\mathrm{B} 2}=56 \mathrm{MPa}$ in [39]. The authors calculate a yield strength for the alloy to be $445 \mathrm{MPa}$, which is reasonably close to the experimental value of $490 \mathrm{MPa}$.

Thus, Gwalani et al. conclude that the combination of $\mathrm{L}_{2}$ and $\mathrm{B} 2$ precipitates provided the best tensile properties for the alloyAl $\mathrm{Co}_{23} \mathrm{Cr}_{23} \mathrm{Fe}_{23} \mathrm{Ni}_{23}$ after thermomechanical treatment cold-rolling $-1150^{\circ} \mathrm{C} 2 \mathrm{~min}$ and $620^{\circ} \mathrm{C} 50 \mathrm{~h}$. It must be noted that this condition leads to a state far from equilibrium of this alloy.

Shun et al. [62] observe tensile properties in the as-cast state which are compared with two annealed states: $700^{\circ} \mathrm{C} 72 \mathrm{~h}$ and $900^{\circ} \mathrm{C} 72 \mathrm{~h}$ (without homogenization), see Table 8 . They do not give any information on grain sizes. 


\begin{tabular}{ccccc}
\hline $\begin{array}{c}\text { Specimen } \\
\text { state }\end{array}$ & Phases & $\boldsymbol{\varepsilon}_{\mathbf{f}}[\% \mathbf{\%}]$ & YS [MPa] & UTS [MPa] \\
\hline as-cast & fcc $+\mathrm{L} 1_{2}$ & $\sim 58$ & $\sim 175$ & $\sim 335$ \\
$700^{\circ} \mathrm{C} 72 \mathrm{~h}$ & fcc $+\mathrm{L} 1_{2}$ & $\sim 44$ & $\sim 305$ & $\sim 525$ \\
$900^{\circ} \mathrm{C} 72 \mathrm{~h}$ & fcc + bcc & $\sim 44$ & $\sim 280$ & $\sim 570$ \\
\hline
\end{tabular}

Table 8: Tensile data of the $\mathrm{Al}_{7} \mathrm{Co}_{23} \mathrm{Cr}_{23} \mathrm{Fe}_{23} \mathrm{Ni}_{23}$ alloy in three different states, with unknown grain size [62]

It is interesting to compare the results of these three studies [39, 60, 62]. Figure 3 compares ultimate tensile strength and elongation to failure as determined in the three articles and summarized in Table 6, 7 and Table 8.

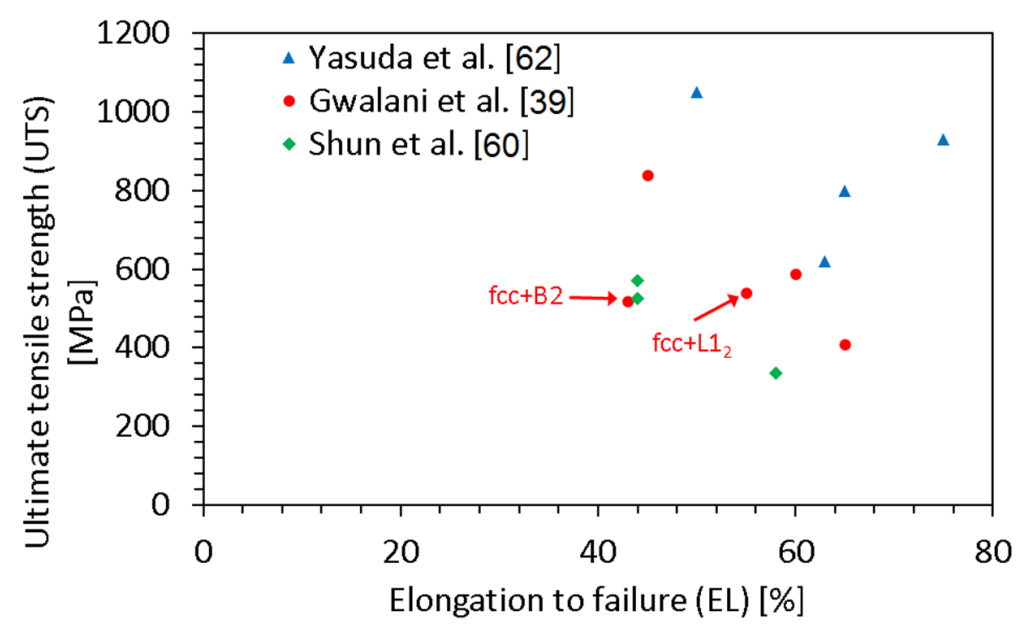

Figure 3: Ultimate tensile strength vs. elongation to failure of $\mathrm{Al}_{7} \mathrm{Co}_{23} \mathrm{Cr}_{23} \mathrm{Fe}_{23} \mathrm{Ni}_{23}$, after different thermo-mechanical heat treatments. Data from [39], [60] and [62]. The arrows indicate the two samples closest to equilibrium.

The best UTS/ $/ \varepsilon_{\mathrm{f}}$ combinations are obtained by the non-equilibrium states after cold-rolling, which is in accordance with many studies on alloys that are neither HEA nor CCA. The red arrows in Figure 3 point to the two states closest to equilibrium, which have been investigated by Gwalani et al. [39]. Their UTS $/ \varepsilon_{\mathrm{f}}$ combinations are among the lowest. The alloy with $\mathrm{L}_{2}$ particles has better properties than the one with $\mathrm{B} 2$ particles.

\subsubsection{CCA with eutectic-like microstructure}

Using the eutectic morphology is one way of obtaining a structure with interpenetrating phases in CCA. In binary systems, eutectic alloys are known to be good candidates for high-temperature applications, because the eutectic solidification microstructure is often controllable and beneficial. The microstructure is fairly resistant even at higher temperatures due to the interrupted diffusion path-ways. Mechanical properties of eutectic binary structures often show high rupture strength, high temperature creep resistance, a stable defect structures, regular lamellar or rod-like eutectic microstructures. Often interesting electric, magnetic and optical properties are observed [66].

The lamellar structure of eutectic microstructures has the tendency to minimize its interfacial energy, e.g. decreasing the surface to volume ratio [67]. Fault migration theory [68] is often used to predict change of lamellar structures [69]. The kinetics of this process is determined by diffusion.

Due to the high number of elements, i.e. $>4$, it is very challenging to reach an exact eutectic composition in a CCA. However, it is possible to obtain a eutectic-like microstructure, which mirrors many of the features 
of a real binary eutectic: lamellar or rod-like morphology, controllable microstructure, deformation resistance at higher temperature.

An interesting aspect about this family of CCA is the fact that eutectic-like structures are present in the ascast state. The dendritic structure is indeed visible, but the difference between dendritic and inter-dendritic region is usually only the morphology, volume fraction and size of the two involved phases, and no big differences in chemical composition in each phase. An example is given in Figure 5 for the AlCoCrFeNi alloy, which is probably the most investigated member of a CCA with eutectic-like microstructure. The inter-dendritic region, on the one hand (marked in red in Figure 5a), shows an interpenetrating network of the bcc and B2 phase (Figure 5b).

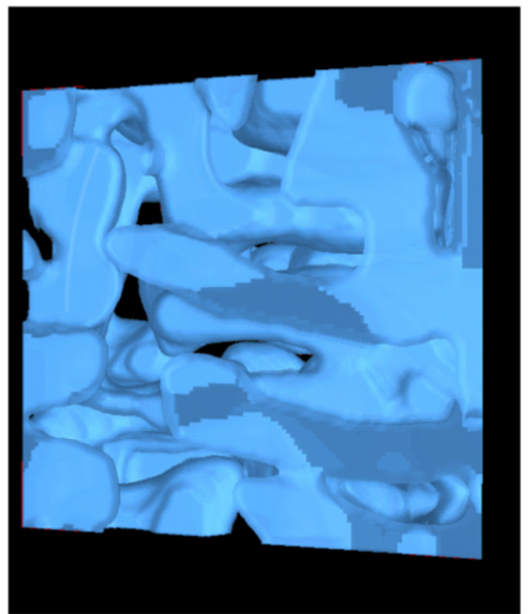

a) Interdendritic region

$\sim(650 \times 620 \times 350) \mathrm{nm}^{3}$ $\sim 52$ vol. \% of the bcc phase

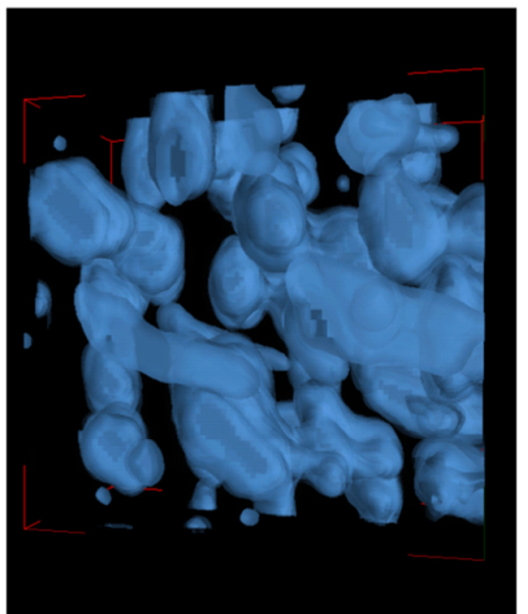

b) Dendritic region $\sim(620 \times 600 \times 300) \mathrm{nm}^{3}$ $\sim 27 \mathrm{vol} . \%$ of the bcc phase

Figure 4: Tomography snapshots of a 3D representation of the $\mathrm{Cr}-\mathrm{Fe}$ rich phase with bcc structure, a) in the interdendritic region and b) in the dendritic region of the AlCoCrFeNi CCA.

This network is best visible in 3D (see the tomography snapshot in Figure 4a) - from 2D observations it can sometimes be concluded that the bcc phase forms individual larger precipitates. The dendritic region, on the other hand (marked in green in Figure 5a), clearly shows individual bcc precipitates embedded in a B2 matrix (see Figure $5 \mathrm{c}$ and the tomography snapshot in Figure $4 \mathrm{~b}$ ). Please note that in this case the interconnecting matrix is an ordered intermetallic B2 phase. 

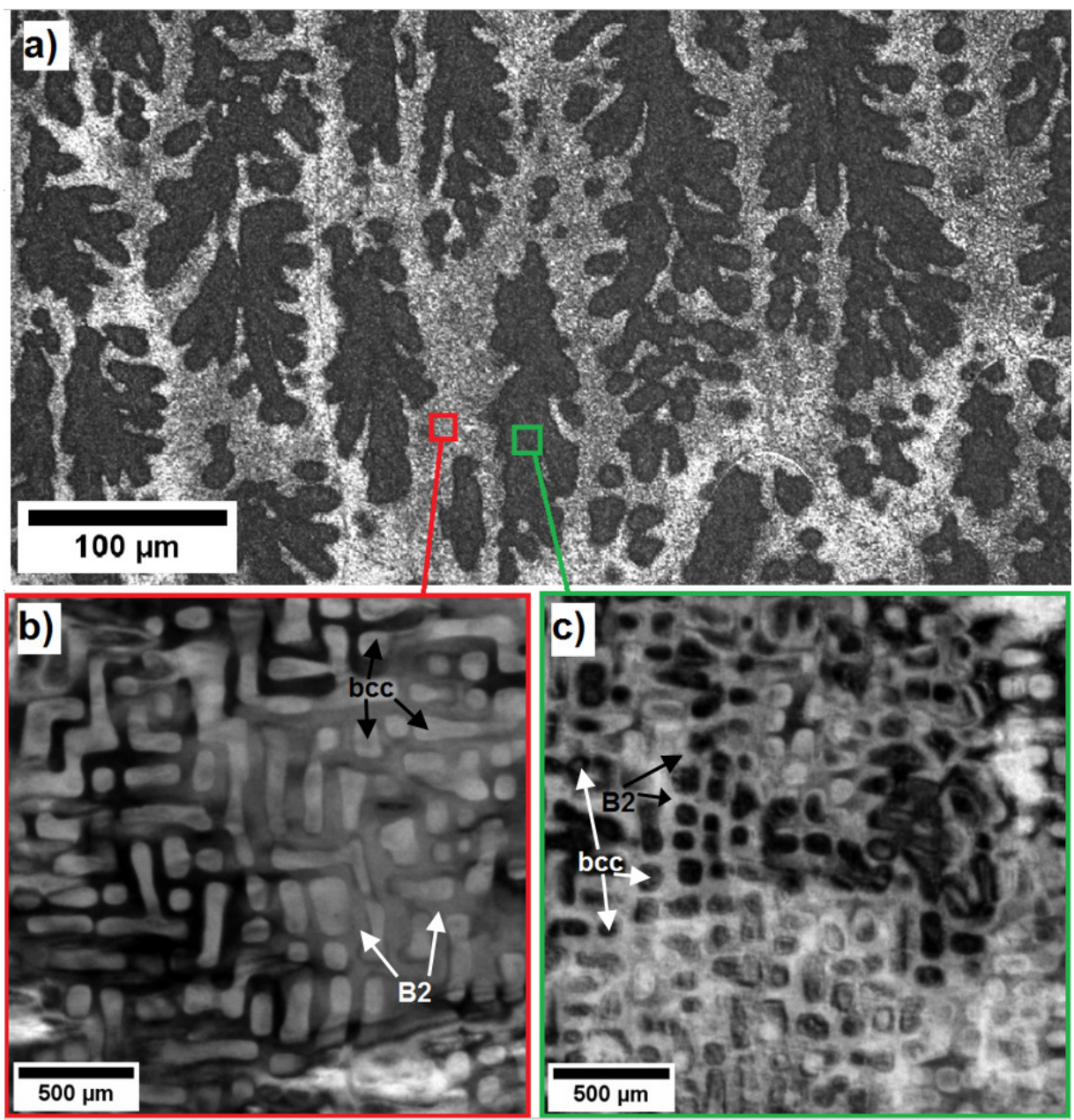

Figure 5: Overview over the dendritic morphology in the as-cast equiatomic AlCoCrFeNi alloy of the family of CCA with eutectic-like microstructure: (a) optical micrograph of the etched alloy, showing the dendritic (dark imaged) and the inter-dendritic (bright imaged) region; (b) BF TEM, taken in the inter-dendritic area, showing the interpenetrating network between B2 and bcc phases; (c) BF TEM, taken in the inter-dendritic area, showing the intermetallic B2 matrix and the bcc precipitates.

Investigations on this group of alloys is usually more oriented towards cost reduction, since a homogenization heat treatment can be omitted (Criterion 4).

\section{a) Equiatomic AlCoCrFeNi:}

Several groups focus on the two-phase aspect of this alloy. The poor ductility in the as-cast state is explained by the lamellar structure [70]. This is why many authors look for an adequate heat treatment, which enhances the ductility of the alloy. This procedure, however, modifies the eutectic morphology and can turn the microstructure into a Ni-base superalloy comparable microstructure of "hard precipitates embedded in a soft matrix". Nevertheless, this alloy remains in the family of CCA with eutectic-like microstructure.

One remarkable thing about this alloy is the fact that a heat treatment can change phases and the literature does not agree on the number and nature of the phases at different temperatures. Munitz et al. [70] work on the equiatomic $\mathrm{AlCoCrFeNi}$ alloy and make a great effort to find the correct homogenization temperature. They claim that even $1200^{\circ} \mathrm{C}$ is not enough to dissolve the dendritic morphology. The also claim that there 
are at least three phases at all temperatures, except for the microstructure of as-cast specimen. From the pictures in their article, it is deduced that the grain size of the alloy is at least $200 \mu \mathrm{m}$. The phase analysis at different temperatures is listed in Table 9 . At $1100^{\circ} \mathrm{C}$ and at $1200^{\circ} \mathrm{C}$ they observe the formation of nanosized precipitates inside the bcc and the $\mathrm{B} 2$ phase. Probably these are the corresponding other phase, proving that at higher temperature the solution limit of both bcc in B2 and B2 in bcc, is reduced. This comprehensive overview shows once more the importance of microstructural investigations at different scales and in all regions of the alloy.

\begin{tabular}{|c|c|c|c|c|}
\hline \multirow[t]{2}{*}{$\begin{array}{l}\text { Specimen } \\
\text { state }\end{array}$} & \multirow[t]{2}{*}{ Function } & \multicolumn{2}{|c|}{ Microstructure } & \multirow{2}{*}{$\begin{array}{c}\text { Phases } \\
\text { detected } \\
\text { by XRD }\end{array}$} \\
\hline & & dendrite & inter-dendritic region & \\
\hline \multirow{2}{*}{ as-cast } & matrix & dark phase & dark phase & \multirow{2}{*}{ bcc, B2 } \\
\hline & precipitates & cubical bright precipitates & faceted bright "precipitates" & \\
\hline \multirow[b]{2}{*}{$850^{\circ} \mathrm{C} 3 \mathrm{~h}$} & matrix & dark phase & dark phase & \multirow[b]{2}{*}{$\begin{array}{l}\text { bcc, } \sigma, \mathrm{B} 2 \\
\text { and fcc }\end{array}$} \\
\hline & precipitates & $\begin{array}{l}\text { cubical bright precipitates and } \\
\text { rectangular bright faceted } \\
\text { particles }\end{array}$ & $\begin{array}{l}\text { greyish non-faceted phase } \\
\text { and bright non-faceted phase }\end{array}$ & \\
\hline \multirow[b]{2}{*}{$975^{\circ} \mathrm{C} 3 \mathrm{~h}$} & matrix & dark phase & dark phase & \multirow{2}{*}{$\begin{array}{l}\mathrm{bcc}, \mathrm{B} 2 \\
\quad \mathrm{fcc}\end{array}$} \\
\hline & precipitates & $\begin{array}{l}\text { bright faceted phase and } \\
\text { greyish non-faceted phase }\end{array}$ & $\begin{array}{l}\text { greyish non-faceted phase } \\
\text { and bright non-faceted phase }\end{array}$ & \\
\hline \multirow[b]{2}{*}{$1100^{\circ} \mathrm{C} 3 \mathrm{~h}$} & matrix & dark phase & dark phase & \multirow[b]{2}{*}{$\begin{array}{l}\mathrm{bcc}, \mathrm{B} 2 \\
\text { and fcc }\end{array}$} \\
\hline & precipitates & $\begin{array}{l}\text { greyish non-faceted phase and } \\
\text { dark cubic fine particles }\end{array}$ & $\begin{array}{l}\text { greyish non-faceted phase, } \\
\text { small cubic dark phase and } \\
\text { bright non-faceted phase }\end{array}$ & \\
\hline \multirow[b]{2}{*}{$1200^{\circ} \mathrm{C} 3 \mathrm{~h}$} & matrix & dark phase & dark phase & \multirow[b]{2}{*}{$\begin{array}{c}\text { bcc, B2 } \\
\text { and } \\
\text { residual fcc }\end{array}$} \\
\hline & precipitates & nano-metric bright precipitates & $\begin{array}{l}\text { greyish non-faceted phase, } \\
\text { small cubic dark phase and } \\
\text { nano-sized bright particles }\end{array}$ & \\
\hline
\end{tabular}

Table 9: Observed phases in the equiatomic alloy AlCoCrFeNi after different heat treatments. The colour description and wording has been chosen by Munitz et al. and refers to their back-scattered electron images (see [70]).

The authors continue their investigation with compressive tests and find that the alloy with the heat treatment at highest temperature $\left(1200^{\circ} \mathrm{C} 3 \mathrm{~h}\right)$ shows the best compromise in mechanical properties (Table 10). They attribute this effect to the presence of the nano-scale precipitates within the precipitates after this heat treatment. Their study of crack propagation at $850^{\circ} \mathrm{C}$ and $975^{\circ} \mathrm{C}$, where the alloy is very brittle, reveals that cracks propagate at the inter-dendritic regions or the interface between dendritic and inter-dendritic region. Cracks usually stop when they reach the dendritic region and they try to further propagate in the matrix. The authors claim that their dark imaged matrix phase probably corresponds to the $\sigma$ phase, but in the case of the sample heat treated at $975^{\circ} \mathrm{C}$ the dark imaged matrix phase cannot correspond to the $\sigma$ phase because the $\sigma$ phase does not exist at that temperature, according to XRD. The authors call this alloy a "macrocomposite material", in which the strength is attained by the strong and brittle interdendritic regions and ductility is gained by the softer dendritic regions. 


\begin{tabular}{|c|c|c|c|}
\hline Specimen state & $\begin{array}{c}\text { Compressiv } \\
\varepsilon_{\mathrm{f}}[\%]\end{array}$ & $\begin{array}{c}\text { Compressive } \\
\text { YS [MPa] }\end{array}$ & $\begin{array}{l}\text { Compressive fracture } \\
\text { strength } \sigma_{\mathrm{f}}[\mathrm{MPa}]\end{array}$ \\
\hline as-cast & -10 & 1380 & 2065 \\
\hline $850^{\circ} \mathrm{C} 3 \mathrm{~h}$ & -1.6 & 1430 & 1465 \\
\hline $975^{\circ} \mathrm{C} 3 \mathrm{~h}$ & -2.7 & 1690 & 2020 \\
\hline $1100^{\circ} \mathrm{C} 3 \mathrm{~h}$ & -13 & 1220 & 2050 \\
\hline $1200^{\circ} \mathrm{C} 3 \mathrm{~h}$ & -20 & 1450 & 2500 \\
\hline
\end{tabular}

Table 10: A summary of the compressive yield stress YS, compressive fracture strength $\sigma_{\mathrm{f}}$ and compressive uniform contraction $\varepsilon_{\mathrm{f}}$ for the equiatomic alloy $\mathrm{AlCoCrFeNi}$ alloy in the as-cast condition and after different heat treatments $[70]$.

Ghassemali et al. [71] investigate the equiatomic alloy $\mathrm{AlCoCrFeNi}$ in heat treated condition $\left(1000^{\circ} \mathrm{C} / 6 \mathrm{~h}\right)$ and focus on the bcc / fcc morphology. They claim that this heat treatment provides a microstructure composed mainly of a bcc phase with precipitates of fcc phase. The grain size is about $50 \mu \mathrm{m}$. It is not clarified whether they consider the different morphologies in the dendritic and the inter-dendritic regions (which are visible in their article) and what happens to the B2 phase, which has been observed by Munitz et al. [70]. Their phase analysis is mainly performed with XRD, SEM and EBSD. The bcc matrix phase has a volume fraction of about $79 \%$. The fcc phase has a volume fraction of about $21 \%$ and forms about $10 \mu \mathrm{m}$ long needles inside the grains and can form a precipitate necklace at the grain boundaries.

As there is no information on higher magnifications, the existence of an additional small sized phase cannot be excluded, and is even quite probable, according to the results in [70]. The authors focus on crack propagation in the alloy and they confirm findings by Munitz et al. that the cracks initiate mainly at triple grain boundary junctions where the bcc phase meets. The crack propagates in an intra-granular pathway is hindered by the fcc phase, which seems to deflect or even stop the crack propagation. Tensile tests have been performed on these samples and the results are summarized in Table 11 . The heat treatment $1000^{\circ} \mathrm{C}$ $6 \mathrm{~h}$ improves the UTS by more than two.

From these two works it can be retained that the presence of an fcc phase at the grain boundaries and the formation of nanoscale phases have positive effects on the mechanical properties of the equiatomic alloy $\mathrm{AlCoCrFeNi}$.

Another study on this alloy has been made by Tang et al. [72]. They apply a complex heat treatment, i.e. hot isostatic pressing (HIP) at $1100^{\circ} \mathrm{C} 1 \mathrm{~h}$ under $207 \mathrm{MPa}$ in $\mathrm{Ar}$ atmosphere. The alloys were then cooled to $500^{\circ} \mathrm{C}$ and kept at this temperature until the pressure was released down to $0.1 \mathrm{MPa}(1 \mathrm{~atm})$. Then the alloy was cooled to room temperature. There is no indication on the duration of this cooling process. After HIP, the samples were heat treated at $1150^{\circ} \mathrm{C} 50 \mathrm{~h}$. and cooled at a cooling rate of $10^{\circ} \mathrm{C} / \mathrm{min}$. This heat treatment will be abbreviated by $\mathrm{HIP}-1150^{\circ} \mathrm{C} 50 \mathrm{~h}$. It leads to a microstructure where the dendritic morphology is still visible. Investigations by XRD, SEM, EBSD, EDS and TEM reveal the presence of four phases: bcc, B2, fcc and $\sigma$. Their respective volume fractions are 24, 46, 16 and 14 vol.\%. B2 as the matrix and A1 precipitates at the grain boundaries. The average grain size is about $100 \mu \mathrm{m}$. Both the bcc and the $\sigma$ phase exist in different sizes, from a few nm to networks that completely fill the grains. This is the only work that shows tensile data of the equiatomic alloy AlCoCrFeNi, listed in Table 11. 


\begin{tabular}{cccccc}
\hline Specimen state & Phases & $\boldsymbol{\varepsilon}_{\mathbf{f}}(\mathbf{\%})$ & YS [MPa] & UTS [MPa] & Ref. \\
\hline as-cast & $\mathrm{bcc}+\mathrm{B} 2$ & 1 & 395 & 400 & {$[71]$} \\
$1000^{\circ} \mathrm{C} 6 \mathrm{~h}$ & $\mathrm{bcc}+\mathrm{fcc}$ & 0.8 & $\sim 900$ & 935 & {$[71]$} \\
\hline
\end{tabular}

Table 11: Room temperature tensile data of the heat treated equiatomic CCA AlCoCrFeNi.

\section{b) $\underline{4-c o m p o n e n t ~} \mathrm{Al}_{17} \mathrm{Cr}_{17} \underline{\mathrm{Fe}}_{33} \underline{\mathrm{Ni}_{33}}$ :}

Another example of a CCA with eutectic-like microstructure is the 4-component $\mathrm{Al}_{17} \mathrm{Cr}_{17} \mathrm{Fe}_{33} \mathrm{Ni}_{33}$ alloy. Due to its only four components, this alloy violates our initial definition as given in Table 2 . The authors provide an overview over the microstructure of the as-cast alloy at room temperature and the corresponding tensile tests. Three phases, i.e. fcc, bcc and B2 have been detected via optical microscopy, XRD and TEM. The data is summarized in Table 12.

\begin{tabular}{cccccc}
\hline Alloy & Phases & $\boldsymbol{\varepsilon}_{\mathbf{f}}(\mathbf{\%})$ & YS [MPa] & UTS [MPa] & Ref. \\
\hline as-cast & bcc, fcc, B2 & 17 & 780 & 17 & {$[73]$} \\
\hline
\end{tabular}

Table 12: Tensile data of the as-cast $\mathrm{Al}_{17} \mathrm{Cr}_{17} \mathrm{Fe}_{33} \mathrm{Ni}_{33}$ alloy with eutectic-like microstructure at RT.

\section{c) $\underline{\mathrm{Al}}_{16} \underline{\mathrm{Co}_{16}} \underline{\mathrm{Cr}}_{16} \underline{\mathrm{Fe}}_{16} \underline{\mathrm{Ni}_{34.4}}$}

This alloy composition is claimed to be exactly eutectic by Lu et al. [74]. The authors of this review are sceptic that this is a eutectic composition since the chances to find a eutectic composition in a 5-component system are extremely small. $\mathrm{Lu}$ et al. [74] compare the alloy $\mathrm{Al}_{16} \mathrm{Co}_{16} \mathrm{Cr}_{16} \mathrm{Fe}_{16} \mathrm{Ni}_{34.4}$ with $\mathrm{Al}_{17} \mathrm{Co}_{17} \mathrm{Cr}_{17} \mathrm{Fe}_{17} \mathrm{Ni}_{33.3}$ and $\mathrm{Al}_{16} \mathrm{Co}_{16} \mathrm{Cr}_{16} \mathrm{Fe}_{16} \mathrm{Ni}_{35.5}$. The aim of the study is to provide a usable CCA in the as-cast state at an industrial scale. Therefore, the alloy is not homogenized. Tensile test have been done at three different temperatures, i.e. room temperature, $-70^{\circ} \mathrm{C}$ and $-196^{\circ} \mathrm{C}$ [74].

\begin{tabular}{cccccc}
\hline Alloy and state & $\mathbf{T}^{\circ}$ & Phases & $\begin{array}{c}\boldsymbol{\varepsilon}_{\mathbf{f}} \\
{[\%]}\end{array}$ & $\begin{array}{c}\text { YS } \\
{[\mathbf{M P a}]}\end{array}$ & $\begin{array}{c}\text { UTS } \\
{[\mathbf{M P a}]}\end{array}$ \\
\hline $\mathrm{Al}_{17} \mathrm{Co}_{17} \mathrm{Cr}_{17} \mathrm{Fe}_{17} \mathrm{Ni}_{33.3}$ & $\mathrm{RT}$ & $\mathrm{L} 1_{2} \& \mathrm{~B} 2$ & 16.5 & 545 & $\sim 1030$ \\
$\mathrm{Al}_{16} \mathrm{Co}_{16} \mathrm{Cr}_{16} \mathrm{Fe}_{16} \mathrm{Ni}_{34.4}$ & $\mathrm{RT}$ & $\mathrm{L} 1_{2} \& \mathrm{~B} 2$ & 16.5 & 545 & $\sim 1050$ \\
$\mathrm{Al}_{16} \mathrm{Co}_{16} \mathrm{Cr}_{16} \mathrm{Fe}_{16} \mathrm{Ni}_{35.5}$ & $\mathrm{RT}$ & $\mathrm{L} 1_{2} \& \mathrm{~B} 2$ & 20 & 545 & $\sim 1110$ \\
\hline $\mathrm{Al}_{17} \mathrm{Co}_{17} \mathrm{Cr}_{17} \mathrm{Fe}_{17} \mathrm{Ni}_{33.3}$ & $-70^{\circ} \mathrm{C}$ & & 10.5 & 580 & 1034 \\
$\mathrm{Al}_{16} \mathrm{Co}_{16} \mathrm{Cr}_{16} \mathrm{Fe}_{16} \mathrm{Ni}_{34.4}$ & $-70^{\circ} \mathrm{C}$ & & 15.8 & 595 & 1168 \\
$\mathrm{Al}_{16} \mathrm{Co}_{16} \mathrm{Cr}_{16} \mathrm{Fe}_{16} \mathrm{Ni}_{35.5}$ & $-70^{\circ} \mathrm{C}$ & & 18 & 570 & 1143 \\
\hline $\mathrm{Al}_{17} \mathrm{Co}_{17} \mathrm{Cr}_{17} \mathrm{Fe}_{17} \mathrm{Ni}_{33.3}$ & $-192^{\circ} \mathrm{C}$ & & 4 & 700 & $1000-1100$ \\
$\mathrm{Al}_{16} \mathrm{Co}_{16} \mathrm{Cr}_{16} \mathrm{Fe}_{16} \mathrm{Ni}_{34.4}$ & $-192^{\circ} \mathrm{C}$ & & 7 & 700 & $1000-1100$ \\
$\mathrm{Al}_{16} \mathrm{Co}_{16} \mathrm{Cr}_{16} \mathrm{Fe}_{16} \mathrm{Ni}_{35.5}$ & $-192^{\circ} \mathrm{C}$ & & 9 & 700 & $1000-1100$ \\
\hline
\end{tabular}

Table 13: Tensile data for three alloys with varying Ni-content at different testing temperatures

A former study by the same group of authors compares the $\mathrm{Al}_{16} \mathrm{Co}_{16} \mathrm{Cr}_{16} \mathrm{Fe}_{16} \mathrm{Ni}_{34.4}$ composition in the ascast state to a cold-rolled state [32]. The microstructure is maintained after cold-rolling. They find a good strengthening effect due to cold-rolling. However, the publication gives only information about the true stress and strain and thus the data is not comparable with other data of this review. 


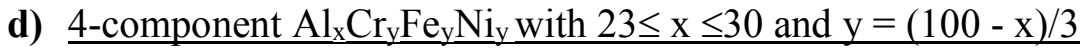

This set of alloys has been studied in the as-cast condition by Chen et al. [75]. Due to its only four components it does not fulfil the stringent original definition, see Table 2. However, it is a good example for the eutectic-like microstructure in a multicomponent alloy, which is maintained over a wide range of $\mathrm{Al}$ content from 23 to 30 at.\%. The paper provides a comparison of compressive data of several as-cast alloys. Although the compression test do not fulfil Criterion 6, the summarizing table (Table 25) gives a good overview over the magnitude of compressive data in CCA and HEA and especially the remarkable properties of the CCA in compression [75].

\subsubsection{Classic alloys like steels, Ni-or Co-based superalloys as starting points for CCA or HEA}

In the last few years the concept of creating multi-phase CCA that approach classic alloys has become more popular. Classic alloys are extremely well studied and their good properties are tried to transfer towards CCA. This is especially important in high temperature applications with high-temperature strength and creep resistance. A controlled formation of desired phases is what characterizes this family of CCA. In most cases the chosen mechanism for alloy improvement is precipitate hardening in combination with solid solution strengthening of the matrix [28-30, 38, 76-89]. Several types of precipitate strengthening in CCA can be differentiated in the literature. Mainly five groups are used for this strengthening mechanism:
A) bec matrix strengthened by an incoherent $\mathrm{B} 2$ phase [77]
B) bcc matrix strengthened by hcp phase [84]
C) fcc matrix strengthened by $\sigma$ and $\mu$ phase $[79,85]$
D) fcc matrix strengthened by a carbide phase [38]
E) fcc matrix strengthened by coherent $\mathrm{L} 1_{2}$ phase (with and without additional phases) [28-30, 40, $76,78,86-89]$

These five groups are presented in the following.

A. B2 in bec matrix

\section{$\underline{\mathrm{Al}_{12} \mathrm{Co}_{18} \mathrm{Cr}_{18} \mathrm{Fe}_{35} \mathrm{Ni}_{18}}$}

This alloy, investigated by Wang et al. [77] shows a very promising microstructure of coherent B2 precipitates in a bcc matrix. The alloy has been suction cast but not homogenized and thus the dendritic morphology remains in the alloy and a third fcc phase is located at the grain boundaries.

It is assumed that the adequate heat treatment and subsequent annealing optimizes the bcc/B2 structure, which is why we will focus now on these two phases. The B2 particles are cuboidal and have sizes of about $100 \mathrm{~nm}$. They seem to be coherent to the bcc matrix.

Compressive and tensile tests have been made at different temperatures, and the results are summarized in Table 14. 


\begin{tabular}{cccc}
\hline Testing temperature & $\boldsymbol{\varepsilon}_{\mathbf{f}}[\mathbf{\%}]$ & YS [MPa] & UTS [MPa] \\
\hline \multicolumn{5}{c}{ Tensile tests } \\
\hline $\mathrm{RT}$ & 7.9 & 866 & 1223 \\
$650^{\circ} \mathrm{C}$ & $\sim 6.3$ & $\sim 400$ & 468 \\
$700^{\circ} \mathrm{C}$ & $\sim 5.4$ & $\sim 220$ & 340 \\
\hline Testing temperature & $\boldsymbol{\varepsilon}_{\mathbf{f}}[\%]$ & YS [MPa] & $\boldsymbol{\sigma}_{\mathbf{f}}[\mathbf{M P a}]$ \\
\hline \multicolumn{5}{c}{ Compressive tests } \\
\hline $\mathrm{RT}$ & -30.2 & 1166 & 1945 \\
\hline
\end{tabular}

Table 14: Tensile and compressive data for the as-cast $\mathrm{Al}_{12} \mathrm{Co}_{18} \mathrm{Cr}_{18} \mathrm{Fe}_{35} \mathrm{Ni}_{18}$ alloy at different testing temperatures [77]

This work is a good example on how compressive test can provide impressive and (from an application standpoint unrealistic) high values compared to tensile tests. The authors also compare the alloy to several other CCA and to commercial Ni-based superalloys in different conditions. They reflect on the lattice misfit between the bcc and the B2 phase and the possible influence of the fcc phase at the grain boundaries.

This alloy shows astonishingly good tensile properties in the as-cast state. More experiments at a more defined heat treatment would be most welcome.

B. bcc strengthened by hep phase

\section{$\underline{\text { Equiatomic HfNbTaTiZr }}$}

The equiatomic alloy HfNbTaTiZr has been recognized as single-phase high entropy alloys [11, 84, 90-92]. It has a bcc structure and the high melting point above $1850^{\circ} \mathrm{C}$ [90] and the usage of oxygen affine elements makes the handling way more difficult than the lower melting point alloys of the Co-Cr-Fe-Ni family. Homogenization, for example, is much harder to achieve.

In the recent work by Stepanov et al. [84] the alloy has been homogenized at $1200^{\circ} \mathrm{C}$ for $24 \mathrm{~h}$ and the dendritic segregations are smoothened. The formation of a second phase, hcp Hf-Ta rich precipitates, is realized after different annealing procedures. The same phase has been induced into the material by deformation at elevated temperature $[90,91,93]$. In [84], hardness has been measured in all states. The results are summarized in Table 15.

\begin{tabular}{cccc}
\hline Specimen state & $\begin{array}{c}\text { hep phase } \\
\text { vol. \% }\end{array}$ & hep phase size & HV0.2 \\
\hline $1200^{\circ} \mathrm{C} / 24 \mathrm{~h}$ & - & - & 370 \\
$1200^{\circ} \mathrm{C} / 24 \mathrm{~h}-600^{\circ} \mathrm{C} / 10 \mathrm{~h}$ & $\sim 20$ & $\begin{array}{c}25 \text { (grain) / several hundred } \\
\text { nm (grain boundaries) }\end{array}$ & 500 \\
$1200^{\circ} \mathrm{C} / 24 \mathrm{~h}-600^{\circ} \mathrm{C} / 100 \mathrm{~h}$ & Not given & $\begin{array}{c}\text { Basket-like structure with } \\
\text { the bcc matrix } \\
\text { Several microns, chains at } \\
\text { (sub) grain boundaries }\end{array}$ & $\sim 370$ \\
$1200^{\circ} \mathrm{C} / 24 \mathrm{~h}-800^{\circ} \mathrm{C} / 10 \mathrm{~h}$ & $\sim 12$ & $\begin{array}{c}\text { Several microns, chains at } \\
\text { (sub) grain boundaries }\end{array}$ & $\sim 370$ \\
$1200^{\circ} \mathrm{C} / 24 \mathrm{~h}-800^{\circ} \mathrm{C} / 100 \mathrm{~h}$ & $\sim 21$ & sing \\
\hline
\end{tabular}

Table 15: hcp phase volume fraction, size and micro-hardness in different states of the equiatomic alloy HfNbTaTiZr [84]. 
The highest hardness is achieved in the state that formed nano-sized hep particles: $600^{\circ} \mathrm{C} 10 \mathrm{~h}$.

It is interesting to note that the formation of the second phase has a much higher impact on micro-hardness than the cold-rolling to two different deformation degrees, which has been performed in [91]. Cold-rolling to a total reduction of $65 \%$ or $86 \%$ implies micro-hardness values of 366 and $367 \mathrm{HV}$ with no significant change to the value of $370 \mathrm{HV}$ of the homogenized state.

C. $\sigma$ and $\mu$ phase

Precipitations with topologically close-packed (TCP) structure, such as $\sigma$ and $\mu$ phases, have an extremely high hardness in the order of $15 \mathrm{GPa}$, as measured with a nano-indenting atomic force microscope and using the measured load displacement curve for calculating the hardness [94]. This causes a noticeable degradation of the high-temperature performance of Ni-based superalloys, due to the stress concentration of the generally needle shaped TCP precipitates [95]. Therefore, their formation has to be avoided via carefully controlling the composition.

\section{a) $\mu$ phase in $\mathrm{C}_{035} \mathrm{Cr}_{15} \mathrm{Fe}_{20} \mathrm{Ni}_{20} \mathrm{Mo}_{10}$}

This alloy, studied by Ming et al. [85] has a unique strengthening second phase, i.e. the $\mu$ phase, if homogenization is applied correctly. The as-cast $\mathrm{Co}_{35} \mathrm{Cr}_{15} \mathrm{Fe}_{20} \mathrm{Ni}_{20} \mathrm{Mo}_{10}$ is a single-phase HEA with fcc structure and it exhibit an exceptional ductility and strain hardening capability associated with twinning. The correct thermomechanical treatment can lead to a two-phase microstructure of an fcc matrix and nanoscale precipitates of a Mo-rich $\mu$ phase. These primarily grow at grain and twin boundaries, thus strengthening the alloy considerably. The samples are heat treated at $1200^{\circ} \mathrm{C} 48 \mathrm{~h}$ and then cooled in the furnace. The subsequent complex thermomechanical treatment violates our equilibrium condition (Criterion 5 in Table 2). The results of the tensile tests of this alloy in these different states are worth to notice, see Table 16.

\begin{tabular}{|c|c|c|c|c|}
\hline Specimen state & Phases & $\begin{array}{c}\mathcal{E}_{\mathrm{f}} \\
{[\%]}\end{array}$ & $\begin{array}{c}\text { YS } \\
{[\mathrm{MPa}]}\end{array}$ & $\begin{array}{c}\text { UTS } \\
{[\mathrm{MPa}]}\end{array}$ \\
\hline $1200^{\circ} \mathrm{C} 48 \mathrm{~h}$ & fcc & 21.9 & 350 & 720 \\
\hline $1200^{\circ} \mathrm{C} 48 \mathrm{~h}-\mathrm{hr} 1100^{\circ} \mathrm{C}-\mathrm{cr}-800^{\circ} \mathrm{C} 1 \mathrm{~h} / \mathrm{ac}$ & $\mathrm{fcc}+\mu$ & 12.1 & 1311 & 1410 \\
\hline $1200^{\circ} \mathrm{C} 48 \mathrm{~h}-\mathrm{hr} 1100^{\circ} \mathrm{C}-\mathrm{cr}-850{ }^{\circ} \mathrm{C} 5 \mathrm{~min} . / \mathrm{wq}$ & $\mathrm{fcc}+\mu$ & 14.9 & 1212 & 1360 \\
\hline $1200^{\circ} \mathrm{C} 48 \mathrm{~h}-\mathrm{hr} 1100^{\circ} \mathrm{C}-\mathrm{cr}-900^{\circ} \mathrm{C} 5 \mathrm{~min} . / \mathrm{wq}$ & $\mathrm{fcc}+\mu$ & 18.3 & 1028 & 1249 \\
\hline $1200^{\circ} \mathrm{C} 48 \mathrm{~h}-\mathrm{hr} 1100^{\circ} \mathrm{C}-\mathrm{cr}-1000^{\circ} \mathrm{C} 5 \mathrm{~min} . / \mathrm{wq}$ & $\mathrm{fcc}+\mu$ & 25.4 & 879 & 1194 \\
\hline $1200^{\circ} \mathrm{C} 48 \mathrm{~h}-\mathrm{hr} 1100^{\circ} \mathrm{C}-\mathrm{cr}-1000^{\circ} \mathrm{C} 1 \mathrm{~h} / \mathrm{ac}$ & $\mathrm{fcc}+\mu$ & 28.2 & 799 & 1127 \\
\hline $1200^{\circ} \mathrm{C} 48 \mathrm{~h}-\mathrm{hr} 1100^{\circ} \mathrm{C}-\mathrm{cr}-1150^{\circ} \mathrm{C} 1 \mathrm{~h} / \mathrm{ac}$ & fcc & 62.4 & 350 & 918 \\
\hline
\end{tabular}

Table 16: Tensile data for the alloy $\mathrm{Co}_{35} \mathrm{Cr}_{15} \mathrm{Fe}_{20} \mathrm{Ni}_{20} \mathrm{Mo}_{10}$ after different thermo-mechanical treatments [85]. ac: air cooling; wq- water quenching; hr - hot rolling; cr - cold rolling.

The average size of the $\mu$ particles in the annealed state $\left(800-1000^{\circ} \mathrm{C}\right)$ is in the range of only $80-200 \mathrm{~nm}$. They are distributed both at the grain boundaries and inside the grains. The latter act as obstacles for moving dislocations and thus strengthen the material. With increasing annealing temperature, more precipitates grow at the boundaries, which thereby decrease this effect.

The authors of [85] found that the strain-hardening rate is independent of the size and number of the $\mu$ phase precipitates. They attribute this to a pronounced solution strengthening effect of Mo addition onto the single phase $\mathrm{Co}_{35} \mathrm{Cr}_{15} \mathrm{Fe}_{20} \mathrm{Ni}_{20} \mathrm{Mo}_{10}$ alloy. They deduce this from the higher strain hardening rate of the single-phase 
alloy after the true strain exceeds $13 \%$. Nano-twinning also is an important modifier of strength, ductility, and strain hardening.

This type of two-phase CCA can further be tuned to comprise nanoscale Mo-rich $\mu$ phase precipitates, achieving the combination of four (!) strengthening mechanisms (solid solution strengthening by Mo, nanotwinning, and precipitate strengthening mechanism by two different precipitates), all due to a complex thermomechanical heat treatment. This method of combining methods and effects is comparable to the one used in the $\mathrm{Al}_{7} \mathrm{Co}_{23} \mathrm{Cr}_{23} \mathrm{Fe}_{23} \mathrm{Ni}_{23}$ alloy in the works of Yasuda et al. [60] and Gwalani et al. [39, 40].

\section{b) $\mathrm{Co}_{\mathrm{y}} \mathrm{Cr}_{\mathrm{y}} \mathrm{Fe}_{\mathrm{y}} \mathrm{Ni}_{\mathrm{y}} \mathrm{Mo}$ with $\mathrm{0} \leq \mathrm{x}<7$ and $\mathrm{y}=(100-\mathrm{x}) / 4$}

This work on $\mathrm{Co}_{\mathrm{y}} \mathrm{Cr}_{\mathrm{y}} \mathrm{Fe}_{\mathrm{y}} \mathrm{Ni}_{\mathrm{y}} \mathrm{Mo}_{\mathrm{x}}$, with $0 \leq \mathrm{x}<7$ and $\mathrm{y}=(100-\mathrm{x}) / 4$, by Liu et al. [79] fulfils four of the six criteria of Table 2and gives some good indications on the influence of the very hard TCP phases, $\sigma$ and $\mu$, in a ductile fcc matrix.

As there is no tensile information on homogenized samples, it is not possible to give a clear summary of the influence of Mo on phase formation and mechanical properties. However, a guess can be made based on the tensile results of the as-cast alloys. Both YS and UTS increase with Mo content, accompanied by a decrease in elongation to failure. The results are summarized in Table 17, along with $\sigma$ or $\mu$ phase sizes. $\mathrm{Co}_{24} \mathrm{Cr}_{24} \mathrm{Fe}_{24} \mathrm{Ni}_{24} \mathrm{Mo}_{2}$ and $\mathrm{Co}_{24} \mathrm{Cr}_{24} \mathrm{Fe}_{24} \mathrm{Ni}_{24} \mathrm{Mo}_{5}$ have been determined to be single phase, but this has only been measured with the lower resolution instruments SEM and XRD and is thus questionable (see Criterion 3 in Table 2). Furthermore, there is no information on the volume fraction of the $\sigma$ or $\mu$ phase in $\mathrm{Co}_{23} \mathrm{Cr}_{23} \mathrm{Fe}_{23} \mathrm{Ni}_{23} \mathrm{Mo}_{7}$ in any state.

\begin{tabular}{|c|c|c|c|c|c|c|}
\hline Alloy & State & $\begin{array}{c}\text { Phases } \\
\text { detected }\end{array}$ & $\sigma / \mu$ size & $\begin{array}{c}\mathcal{E}_{\mathrm{f}} \\
{[\%]}\end{array}$ & $\begin{array}{c}\text { YS } \\
{[\mathbf{M P a}]}\end{array}$ & $\begin{array}{c}\text { UTS } \\
{[\mathrm{MPa}]}\end{array}$ \\
\hline $\mathrm{Co}_{25} \mathrm{Cr}_{25} \mathrm{Fe}_{25} \mathrm{Ni}_{25}$ & as-cast & fcc & - & 58.9 & 155.0 & 472.4 \\
\hline $\mathrm{Co}_{24} \mathrm{Cr}_{24} \mathrm{Fe}_{24} \mathrm{Ni}_{24} \mathrm{Mo}_{2}$ & as-cast & No clear info & No info & 51.1 & 198.8 & 479.0 \\
\hline $\mathrm{Co}_{24} \mathrm{Cr}_{24} \mathrm{Fe}_{24} \mathrm{Ni}_{24} \mathrm{Mo}_{5}$ & as-cast & No clear info & No info & 55.1 & 254.7 & 589.6 \\
\hline $\mathrm{Co}_{23} \mathrm{Cr}_{23} \mathrm{Fe}_{23} \mathrm{Ni}_{23} \mathrm{Mo}_{7}$ & as-cast & $\mathrm{fcc}+\sigma$ & $\begin{array}{l}\text { No clear } \\
\text { info }\end{array}$ & 49.3 & 305.3 & 709.7 \\
\hline $\mathrm{Co}_{23} \mathrm{Cr}_{23} \mathrm{Fe}_{23} \mathrm{Ni}_{23} \mathrm{Mo}_{7}$ & $\mathrm{cr}-850^{\circ} \mathrm{C} 1 \mathrm{~h}$ & fcc, $\sigma, \mu$ (?) & $1-5 \mu \mathrm{m}$ & 18.9 & 815.5 & 1186.5 \\
\hline $\mathrm{Co}_{23} \mathrm{Cr}_{23} \mathrm{Fe}_{23} \mathrm{Ni}_{23} \mathrm{Mo}_{7}$ & $\mathrm{cr}-850^{\circ} \mathrm{C} 1 \mathrm{~h}$ & fcc, $\sigma, \mu$ (?) & $0.2-6 \mu \mathrm{m}$ & 32.5 & 646.7 & 1042.0 \\
\hline $\mathrm{Co}_{23} \mathrm{Cr}_{23} \mathrm{Fe}_{23} \mathrm{Ni}_{23} \mathrm{Mo}_{7}$ & $\begin{array}{c}\mathrm{cr}-900^{\circ} \mathrm{C} 1 \mathrm{~h}- \\
700^{\circ} \mathrm{C} 5 \mathrm{~h}\end{array}$ & fcc, $\sigma, \mu$ (?) & $0.2-3 \mu \mathrm{m}$ & 30.4 & 683.7 & 1066.6 \\
\hline
\end{tabular}

Table 17: $\sigma$ or $\mu$ phase precipitate sizes, engineering yield strength (YS), ultimate tensile strength (UTS), and elongation $\left(\varepsilon_{\mathrm{f}}\right)$ for the as-cast $\mathrm{Co}_{\mathrm{y}} \mathrm{Cr}_{\mathrm{y}} \mathrm{Fe}_{\mathrm{y}} \mathrm{Ni}_{\mathrm{y}} \mathrm{Mo}_{\mathrm{x}}$, with $0 \leq \mathrm{x}<7$ and $\mathrm{y}=(100-\mathrm{x}) / 4$, alloys and the $\mathrm{Mo}_{0.3}$ alloy $60 \%$ rolled and annealed to different states [79].

The lower part of Table 17 is a good example of the additional tuneable influence by a thermomechanical treatment. Very good tensile data can be obtained in the $\mathrm{Co}_{23} \mathrm{Cr}_{23} \mathrm{Fe}_{23} \mathrm{Ni}_{23} \mathrm{Mo}_{7}$ alloy after cold rolling and subsequent heat treatment. However, a comparison of these cold rolled + heat treated states with the as-cast states will not give any information on the influence of the $\sigma$ and $\mu$ phases, because of the highly different grain sizes. Grains in the cold rolled + heat treated $\mathrm{Co}_{23} \mathrm{Cr}_{23} \mathrm{Fe}_{23} \mathrm{Ni}_{23} \mathrm{Mo}_{7}$ alloy are about $15 \mu \mathrm{m}$ in size. There is no information on grain size in the as-cast alloy, but from the SEM information on the equiatomic $\mathrm{CoCrFeNi}$ it can be guessed that it is in the order of several hundred $\mu \mathrm{m}$. Thus, with the given data, it is not possible to clearly conclude whether the transition from single phase equiatomic $\mathrm{CoCrFeNi} \mathrm{HEA}$ to the three-phase $\mathrm{CCA} \mathrm{Co}{ }_{23} \mathrm{Cr}_{23} \mathrm{Fe}_{23} \mathrm{Ni}_{23} \mathrm{Mo}_{7}$ is positive in terms of tensile data. 


\section{c) $\mathrm{Co}_{\mathrm{y}} \mathrm{Cr}_{\mathrm{y}} \mathrm{Fe}_{\mathrm{y}} \mathrm{Mn}_{\mathrm{y}} \mathrm{Ni}_{\mathrm{y}} \mathrm{V}_{\mathrm{x}}$ with $0 \leq \mathrm{x} \leq 17$ and $\mathrm{y}=(100-\mathrm{x}) / 5$}

$\mathrm{V}$ additions are used in this work by Shaysultanov et al. [96] to add a hardening $\sigma$ phase to the wellinvestigated single-phase HEA CoCrFeMnNi (often referred to as Cantor alloy [4, 5]). Alloys are heat treated at different temperatures and then analysed mainly by SEM and, to a lesser extent, TEM. The heat treatment at $1100^{\circ} \mathrm{C}$ provides a homogenization of the alloy but the lower temperatures do not. There is no annealing after the homogenization. Five different alloys have been investigated, the equiatomic 5component Cantor alloy CoCrFeMnNi, $\mathrm{Co}_{19} \mathrm{Cr}_{19} \mathrm{Fe}_{19} \mathrm{Mn}_{19} \mathrm{Ni}_{19} \mathrm{~V}_{5}, \quad \mathrm{Co}_{18} \mathrm{Cr}_{18} \mathrm{Fe}_{18} \mathrm{Mn}_{18} \mathrm{Ni}_{18} \mathrm{~V}_{9}$, $\mathrm{Co}_{17} \mathrm{Cr}_{17} \mathrm{Fe}_{17} \mathrm{Mn}_{17} \mathrm{Ni}_{17} \mathrm{~V}_{13}$, and the again equiatomic, now six-component alloy CoCrFeMnNiV.

Increasing $\mathrm{V}$ content increases the volume fraction of $\sigma$ and the micro-hardness, as is made visible by Shaysultanov et al. [96] in Figure 6. The size of the $\sigma$ particles in the homogenized alloys and their volume fraction is summarized in Table 18. At low V content the fcc phase is always the matrix. At 17 at.\% V, the relationship of the phases reverses and the $\sigma$ phase becomes the matrix and the fcc phase precipitates inside the $\sigma$ phase.

\begin{tabular}{ccc}
\hline Alloy & Size of the $\boldsymbol{\sigma}$ phase & $\boldsymbol{\sigma}$ volume fraction (\%) \\
\hline $\mathrm{Co}_{20} \mathrm{Cr}_{20} \mathrm{Fe}_{20} \mathrm{Mn}_{20} \mathrm{Ni}_{20}$ & - & - \\
$\mathrm{Co}_{19} \mathrm{Cr}_{19} \mathrm{Fe}_{19} \mathrm{Mn}_{19} \mathrm{Ni}_{19} \mathrm{~V}_{5}$ & Undetectable by SEM and XRD & $\sim 0$ \\
$\mathrm{Co}_{18} \mathrm{Cr}_{18} \mathrm{Fe}_{18} \mathrm{Mn}_{18} \mathrm{Ni}_{18} \mathrm{~V}_{9}$ & $8-50 \mu \mathrm{m}$ & $\sim 19$ \\
$\mathrm{Co}_{17} \mathrm{Cr}_{17} \mathrm{Fe}_{17} \mathrm{Mn}_{17} \mathrm{Ni}_{17} \mathrm{~V}_{13}$ & $8-100 \mu \mathrm{m}$ & $\sim 42$ \\
equiatomic & matrix phase & $\sim 60$ \\
$\mathrm{Co}_{17} \mathrm{Cr}_{17} \mathrm{Fe}_{17} \mathrm{Mn}_{17} \mathrm{Ni}_{17} \mathrm{~V}_{17}$ & & \\
\hline
\end{tabular}

Table 18: $\sigma$ precipitate sizes in five different alloys with varying $\mathrm{V}$ content after homogenization at $1100^{\circ} \mathrm{C} 24 \mathrm{~h}$ [96].

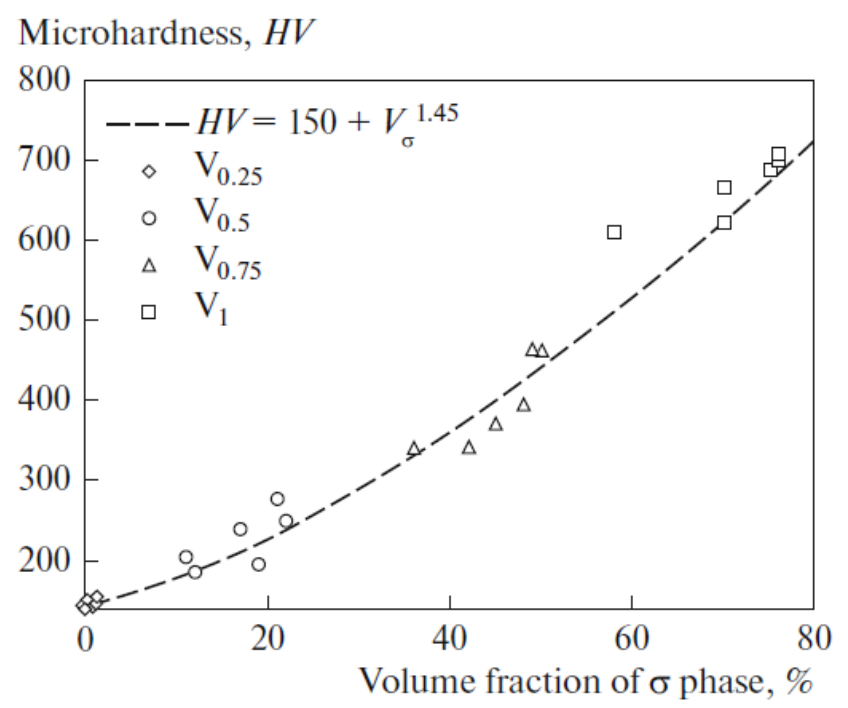

Figure 6: Relationships between $\mathrm{V}$ content, $\sigma$ volume fraction and micro-hardness in the $\mathrm{CoCrFeMnNiV}_{\mathrm{x}}$ alloys from [96]. No information is given on the heat treatment in this graph. Reprinted by permission from Springer Nature: Physics of Metals and Metallography, Effect of heat treatment on the structure and hardness of high-entropy alloys CoCrFeNiMnVx $(x=0.25,0.5,0.75,1)$, D. G. Shaysultanov, N. D. Stepanov, G. A. Salishchev et al., Copyright (2017) 
$\sigma$ volume fraction and micro-hardness investigations at lower temperatures show higher values for these two parameters. It is thus assumed that an annealing treatment at $900^{\circ} \mathrm{C}$ after homogenization at $1100^{\circ} \mathrm{C}$, would further improve the hardness of the alloy.

Earlier investigations of the same group of authors [83] compares the $\mathrm{V}$ content to compression properties. However, a homogenization of the alloys is not carried out, since the chosen temperature of $1000^{\circ} \mathrm{C}$ is too low for a proper homogenization. However, an interesting point has to be noted: in the $1000^{\circ} \mathrm{C} 24 \mathrm{~h}$ annealed samples an increase of the $\sigma$ phase volume fraction above 40 vol.\% results in an abrupt decrease of the compression fracture strain $\varepsilon_{\mathrm{f}}$ in compr. Volume fractions and compression data of the $1000^{\circ} \mathrm{C} 24 \mathrm{~h}$ annealed alloys with varying $\mathrm{V}$ content are listed in Table 19.

\begin{tabular}{ccccc}
\hline Specimen state & $\begin{array}{c}\boldsymbol{\sigma} \text { volume } \\
\text { fraction } \\
(\%)\end{array}$ & $\begin{array}{c}\text { Compressive } \\
\boldsymbol{\varepsilon}_{\mathbf{f}}[\% \mathbf{\%}]\end{array}$ & $\begin{array}{c}\text { Compressive } \\
\text { YS [MPa] }\end{array}$ & $\begin{array}{c}\text { Compressive } \\
\text { fracture strength } \\
\boldsymbol{\sigma}_{\mathbf{f}}[\mathbf{M P a}]\end{array}$ \\
\hline equiatomic 5-comp. & - & $\sim-75$ & 230 & $>1400$ \\
$\mathrm{Co}_{20} \mathrm{Cr}_{20} \mathrm{Fe}_{20} \mathrm{Mn}_{20} \mathrm{Ni}_{20}$ & & & & \\
$\mathrm{Co}_{19} \mathrm{Cr}_{19} \mathrm{Fe}_{19} \mathrm{Mn}_{19} \mathrm{Ni}_{19} \mathrm{~V}_{5}$ & insignificant & $\sim-75$ & 200 & $>1400$ \\
$\mathrm{Co}_{18} \mathrm{Cr}_{18} \mathrm{Fe}_{18} \mathrm{Mn}_{18} \mathrm{Ni}_{18} \mathrm{~V}_{9}$ & 28 & -75 & 620 & $>1500$ \\
$\mathrm{Co}_{17} \mathrm{Cr}_{17} \mathrm{Fe}_{17} \mathrm{Mn}_{17} \mathrm{Ni}_{17} \mathrm{~V}_{13}$ & $\sim 48$ & $\sim-8$ & $\sim 780$ & 1320 \\
equiatomic six-comp. & $\sim 73$ & $\sim-1$ & $\sim 1700$ & 1845 \\
$\mathrm{Co}_{17} \mathrm{Cr}_{17} \mathrm{Fe}_{17} \mathrm{Mn}_{17} \mathrm{Ni}_{17} \mathrm{~V}_{17}$ & & & & \\
\hline
\end{tabular}

Table 19: $\sigma$ phase volume fraction and compression data in the $1000^{\circ} \mathrm{C} 24 \mathrm{~h}$ annealed state of alloys with varying $\mathrm{V}$ content [83].

In summary, the increase of $\sigma$ phase, which is directly linked to a higher $\mathrm{V}$ content, increases the hardness and compression yield strength, but decreases ductility. Unfortunately, there is no information on whether the presence of the $\sigma$ phase has also a positive influence on tensile properties.

D. Carbide strengthening of the Cantor alloy

Until now there is only one paper that has specialized on the influence of carbides onto the HEA Cantor alloy. Cheng et al.[38] investigate the Cantor alloy, with the additions of 2 at. \% C. The Cantor alloy with and without carbon are forged at $700^{\circ} \mathrm{C}$ and then homogenized at $1000^{\circ} \mathrm{C} 6 \mathrm{~h}$. There is no proof that this thermomechanical treatment is sufficient for removing the dendritic structure.

The two alloys are then cold rolled and annealed at $900^{\circ} \mathrm{C} 6 \mathrm{~h}$. This allows the comparison of four different samples. 


\begin{tabular}{|c|c|c|c|c|c|c|c|}
\hline Alloy & State & $\begin{array}{c}\text { Avg. } \\
\text { grain } \\
\text { size } \\
{[\mu \mathrm{m}]} \\
\end{array}$ & $\begin{array}{c}\mathrm{Cr}_{23} \mathrm{C}_{6} \\
\text { volume } \\
\text { fraction } \\
{[\%]}\end{array}$ & $\begin{array}{c}\mathrm{Cr}_{23} \mathrm{C}_{6} \\
\text { size } \\
{[\mu \mathrm{m}]}\end{array}$ & $\begin{array}{c}\text { YS } \\
{[\mathrm{MPa}]}\end{array}$ & $\begin{array}{c}\text { UTS } \\
\text { [MPa] }\end{array}$ & $\begin{array}{c}\varepsilon_{\mathrm{f}} \\
{[\%]}\end{array}$ \\
\hline Cantor & $\begin{array}{c}\text { forged } 700^{\circ} \mathrm{C}- \\
1000^{\circ} \mathrm{C} 6 \mathrm{~h}\end{array}$ & 13 & - & - & 243 & 558 & 50 \\
\hline $\begin{array}{c}\text { Cantor }+2 \\
\text { at. } \% \mathrm{C}\end{array}$ & $\begin{array}{l}\text { forged } 700^{\circ} \mathrm{C}- \\
1000^{\circ} \mathrm{C} 6 \mathrm{~h}\end{array}$ & 8 & - & - & 249 & 621 & 41 \\
\hline Cantor & $\begin{array}{l}\text { forged } 700^{\circ} \mathrm{C}- \\
1000^{\circ} \mathrm{C} 6 \mathrm{~h}-\mathrm{cr}- \\
900^{\circ} \mathrm{C} 6 \mathrm{~h}\end{array}$ & 7 & 11.9 & $\begin{array}{c}0.3- \\
1.2\end{array}$ & 446 & 723 & 15 \\
\hline $\begin{array}{c}\text { Cantor }+2 \\
\text { at. } \% \mathrm{C}\end{array}$ & $\begin{array}{c}\text { forged } 700^{\circ} \mathrm{C}- \\
1000^{\circ} \mathrm{C} 6 \mathrm{~h}-\mathrm{cr}- \\
900^{\circ} \mathrm{C} 6 \mathrm{~h}\end{array}$ & 4 & 13.6 & $\begin{array}{l}0.4- \\
1.5\end{array}$ & 581 & 857 & 28 \\
\hline
\end{tabular}

Table 20: Carbon influence on tensile data in the Cantor equiatomic alloy CoCrFeMnNi [38]; cr: cold-rolling

E. $\mathrm{L}_{2}$ strengthening of an fcc matrix, with or without an additional phase

This type of strengthening precipitates is very well known from Ni-base superalloys [97, 98]. It is used in many fcc based CCA [29, 47, 99-103], but their influence on mechanical properties have been analysed in detail in only a few works.

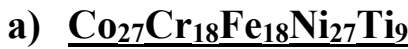

Yeh et al. $[104,105]$ also propose the $\mathrm{L}_{2}$ precipitation hardening as a promising strengthening mechanism in the $\mathrm{Co}_{27} \mathrm{Cr}_{18} \mathrm{Fe}_{18} \mathrm{Ni}_{27} \mathrm{Ti}_{9}$ alloy and its successors, which contain a much higher percentage in Ni. They introduce the term high entropy superalloys (HESA).They investigate different heat treatments of the alloy. As there is neither a clear homogenization (Criterion 4, Table 2) nor information on mechanical or other properties (Criterion 5) it is only possible to make assumptions on the role of the $\gamma^{\prime}$ precipitates. They are fairly small in size $(\sim 70 \mathrm{~nm})$ after a heat treatment at $800^{\circ} \mathrm{C} 50 \mathrm{~h}$. An additional $\eta$ phase has been detected in the as-cast state and after heat treatments at higher temperatures $\left(900-1000^{\circ} \mathrm{C}\right)$. It is assumed that this phase is detrimental for mechanical properties.

\section{b) $\underline{A l}_{4} \mathrm{Co}_{24} \mathrm{Cr}_{24} \mathrm{Fe}_{24} \mathrm{Ni}_{24} \mathrm{Ti}_{2}$}

He et al. have been among the first to propose a strengthening mechanism in an fcc based alloy, with strengthening phases of $\mathrm{L}_{2}$ and Heusler type phases [78]. They investigate the multi-phase $\mathrm{CCAAl}_{4} \mathrm{Co}_{24} \mathrm{Cr}_{24} \mathrm{Fe}_{24} \mathrm{Ni}_{24} \mathrm{Ti}_{2}$.

Both the single phase fcc structured equiatomic $\mathrm{CoCrFeNi}$ and the $\mathrm{Co}_{24} \mathrm{Cr}_{24} \mathrm{Fe}_{24} \mathrm{Ni}_{24} \mathrm{Ti}_{2} \mathrm{Al}_{4}$ are homogenized at $1200^{\circ} \mathrm{C} 4 \mathrm{~h}$. In the latter, the homogenization is followed by two complex thermomechanical procedures, which make the detection of the influence of additional phases difficult.

The first thermomechanical treatment (which the authors call P1) includes cold rolling of 30\%, subsequent annealing at $1000^{\circ} \mathrm{C} 2 \mathrm{~h}$, a second annealing step at $800^{\circ} \mathrm{C} 18 \mathrm{~h}$, followed by water quenching. The second thermomechanical treatment (which the authors call P2) includes cold rolling of $70 \%$, annealing at $700^{\circ} \mathrm{C} 4$ $\mathrm{h}$, followed by water quenching. 
The work is a good summary of the influence of the existence and size, volume fraction and type of strengthening precipitates and it uses a wide range of methods for investigation. In the thermo-mechanically treated samples $\mathrm{P} 1$ and $\mathrm{P} 2$ there are two regions $\mathrm{R} 1$ and $\mathrm{R} 2$, which consist of different morphologies of $\mathrm{L} 1_{2}$ precipitates and fcc matrix. The Heusler Phase, $\mathrm{L}_{2}$, has quite a low volume fraction and is distributed homogeneously throughout the alloy. One region consists of spherical $\mathrm{L} 1_{2}$ precipitates with a size $<40 \mathrm{~nm}$, homogenously distributed inside the grain. Another region consists of plate-like $\mathrm{L}_{2}$ precipitates with a width larger than $70 \mathrm{~nm}$ and diameters of up to $2 \mu \mathrm{m}$.

In the sample after $\mathrm{P} 2$ treatment, the $20-100 \mathrm{~nm}$ sized $\mathrm{L} 1_{2}$ precipitates are uniformly distributed. The $\mathrm{L} 2_{1}$ particles are found to be smaller $\sim 100 \mathrm{~nm}$ and they appear as irregular blocks. The authors consider a detailed structure description and strengthening mechanism analysis of this $\mathrm{L} 2{ }_{1}$ not to be important, because of the relative low volume fraction of this phase in both states, P1 and P2.

\begin{tabular}{|c|c|c|c|c|c|c|c|}
\hline Alloy & State & $\begin{array}{c}\text { Phases } \\
\text { detected }\end{array}$ & $\begin{array}{c}\text { Vol. \% } \\
\text { L1 }_{2} / \\
\text { L2 }_{1}\end{array}$ & $\begin{array}{c}\text { Particle } \\
\text { size } \\
{[\mathrm{nm}]}\end{array}$ & $\begin{array}{c}\varepsilon_{\mathrm{f}} \\
{[\%]}\end{array}$ & $\begin{array}{c}\text { YS } \\
{[\mathrm{MPa}]}\end{array}$ & $\begin{array}{c}\text { UTS } \\
\text { [MPa] }\end{array}$ \\
\hline equiatomic $\mathrm{CoCrFeNi}$ & $1200^{\circ} \mathrm{C} 4 \mathrm{~h}$ & fcc & 0 & - & $\sim 70$ & $\sim 190$ & 453 \\
\hline $\mathrm{Al}_{4} \mathrm{Co}_{24} \mathrm{Cr}_{24} \mathrm{Fe}_{24} \mathrm{Ni}_{24} \mathrm{Ti}_{2}$ & $1200^{\circ} \mathrm{C} 4 \mathrm{~h}$ & fcc & 0 & - & $\sim 70$ & $\sim 210$ & 503 \\
\hline $\mathrm{Al}_{4} \mathrm{Co}_{24} \mathrm{Cr}_{24} \mathrm{Fe}_{24} \mathrm{Ni}_{24} \mathrm{Ti}_{2}$ & $\begin{array}{c}1200^{\circ} \mathrm{C} 4 \mathrm{~h}-\mathrm{cr}- \\
1000^{\circ} \mathrm{C} 2 \mathrm{~h}- \\
800^{\circ} \mathrm{C} 18 \mathrm{~h}-\mathrm{wq} \\
(\mathrm{P} 1)\end{array}$ & $\begin{array}{l}\text { fcc, } \mathrm{L}_{2}, \\
\mathrm{~L} 2_{1}\end{array}$ & $\begin{array}{l}23.3 \\
\text { (R1) } \\
16.2 \\
\text { (R2) }\end{array}$ & $\begin{array}{l}12.6 \\
(\mathrm{R} 1) \\
46.3 \\
(\mathrm{R} 2)\end{array}$ & 39 & 645 & 1094 \\
\hline $\mathrm{Al}_{4} \mathrm{Co}_{24} \mathrm{Cr}_{24} \mathrm{Fe}_{24} \mathrm{Ni}_{24} \mathrm{Ti}_{2}$ & $\begin{array}{c}1200^{\circ} \mathrm{C} 4 \mathrm{~h}-\mathrm{cr}- \\
700^{\circ} \mathrm{C} 4 \mathrm{~h}-\mathrm{wq} \\
(\mathrm{P} 2)\end{array}$ & $\begin{array}{c}\mathrm{fcc}, \mathrm{L} 1_{2}, \\
\mathrm{~L} 2_{1}\end{array}$ & $\begin{array}{c}26.8 / \\
2.8\end{array}$ & $\begin{array}{l}9.7 / \\
25.9\end{array}$ & 17 & 1005 & 1273 \\
\hline
\end{tabular}

Table 21: Phases and volume fractions of phases in different states of the $\mathrm{Al}_{4} \mathrm{Co}_{24} \mathrm{Cr}_{24} \mathrm{Fe}_{24} \mathrm{Ni}_{24} \mathrm{Ti}_{2}$ alloy and the corresponding tensile data [78]: cr: cold rolling; wq: water quenching

The authors give a good overview over the different strengthening mechanisms. These are traditionally summarized into four categories: solid-solution hardening, grain-boundary hardening, work hardening, and precipitation hardening. They are operating independently, which means that the yield strength $\sigma_{0.2}$ is a simple summation of the four individual contributions. It can be expressed as follows [106]:

$\sigma_{0.2}=\sigma_{\mathrm{A}}+\Delta \sigma_{\mathrm{ss}}+\Delta \sigma_{\mathrm{gb}}+\Delta \sigma_{\mathrm{wh}}+\Delta \sigma_{\mathrm{ph}}$

Equation 3

where $\sigma_{\mathrm{A}}$ is the intrinsic strength and $\sigma_{\mathrm{ss}}, \sigma_{\mathrm{gb}}, \sigma_{\mathrm{wh}}$ and $\sigma_{\mathrm{ph}}$ are strengthening contributions from solid solution, grain boundary, dislocations, and precipitates, respectively. The authors calculate the influence of each strengthening mechanism in the P1 and P2 alloys and find that the precipitation hardening is the most important one, but about 58 in case of the $\mathrm{P} 1$ state and $36 \%$ in case of $\mathrm{P} 2$.

In P1 it contributes a strength increment of about $327 \mathrm{MPa}$. In alloy P2, the high yield strength results from contributions of precipitation hardening (328 MPa), dislocation hardening (275 MPa), and grain boundary hardening (123 MPa).

Zhao et al. [107] also investigate this alloy and they find a nano-hardness peak for $\mathrm{L}_{2}$ particle sizes of about $24 \mathrm{~nm}$, after homogenization at $1200^{\circ} \mathrm{C} 4 \mathrm{~h}$ and subsequent heat treatments at 750,775 and $800^{\circ} \mathrm{C}$ for 48 , 24 and $17 \mathrm{~h}$, respectively. They attribute this peak to the crossover of weak- and strong-coupling mechanisms. They give a good overview over the particle size evolution with different annealing temperatures and times. 


\section{c) $\mathrm{Al}_{4} \mathrm{Co}_{19} \mathrm{Cr}_{19} \mathrm{Cu}_{4} \mathrm{Fe}_{19} \mathrm{Ni}_{37}$}

The work by Wang et al. [76] offers a good comparison of the effect of $\mathrm{L} 1_{2}$ precipitates on tensile properties in fcc based $\mathrm{Al}_{4} \mathrm{Co}_{19} \mathrm{Cr}_{19} \mathrm{Cu}_{4} \mathrm{Fe}_{19} \mathrm{Ni}_{37}$ alloy. The composition of the alloy is slightly off the definition, since the Ni content is 37 at.\%. The alloy is homogenized at $1200^{\circ} \mathrm{C} 24 \mathrm{~h}$ and then cold-rolled, which makes the comparison to other alloys difficult. However, as the annealing subsequent to cold-rolling produces a singlephase (annealing at $800^{\circ} \mathrm{C} 1 \mathrm{~h}$ ) and a two-phase alloy (annealing at $700^{\circ} \mathrm{C} 20 \mathrm{~h}$ ), the internal comparison gives good insight on the effect of $\mathrm{L}_{2}$ precipitates. The authors state that since the two alloys have nearly identical average grain size, the only difference between the microstructures is the existence of $\mathrm{L} 1_{2}$ nano sized precipitates.

This work is a good example on the importance of TEM investigation. Neither SEM nor XRD reveal the presence of the $\mathrm{L}_{2}$ precipitates. The $\gamma^{\prime}$ precipitates are Al-Cu-Ni rich, about $20 \mathrm{~nm}$ in size and coherently embedded in the fcc matrix. No information is given on their volume fraction.

\begin{tabular}{ccccc}
\hline Specimen state & $\begin{array}{c}\text { Phases } \\
\text { detected }\end{array}$ & $\begin{array}{c}\boldsymbol{\varepsilon}_{\mathrm{f}} \\
{[\%]}\end{array}$ & $\begin{array}{c}\text { YS } \\
{[\mathbf{M P a}]}\end{array}$ & $\begin{array}{c}\text { UTS } \\
{[\mathbf{M P a}]}\end{array}$ \\
\hline $\begin{array}{c}1200^{\circ} \mathrm{C} 24 \mathrm{~h} \\
- \text { cold-rolling }-700^{\circ} \mathrm{C} 20 \mathrm{~h}\end{array}$ & matrix & 30 & 719 & 1048 \\
$\begin{array}{c}1200^{\circ} \mathrm{C} 24 \mathrm{~h} \\
- \text { cold-rolling }-800^{\circ} \mathrm{C} 1 \mathrm{~h}\end{array}$ & $\begin{array}{c}\text { matrix } \\
+\mathrm{L} 1_{2}\left(\gamma^{\prime}\right)\end{array}$ & 32 & 460 & 732 \\
\hline
\end{tabular}

Table 22: The yield strength (YS), ultimate tensile strength (UTS), and elongation $\left(\varepsilon_{f}\right)$ for the homogenized - coldrolled - annealed $\mathrm{Al}_{4} \mathrm{Co}_{19} \mathrm{Cr}_{19} \mathrm{Cu}_{4} \mathrm{Fe}_{19} \mathrm{Ni}_{37}$ alloy at room temperature [76]

An increase of $259 \mathrm{MPa}$ and $316 \mathrm{MPa}$ in the YS and UTS, respectively, can be determined from the single phase to the two-phase state, as is listed in Table 22 . This is accompanied by a large elongation of $30 \%$. The authors give a good discussion on the different strengthening mechanisms and determine the so-called dislocation shearing (which we interpret as shearing of precipitates) to be the main responsible for the precipitation hardening mechanism.

\section{d) $\mathrm{Al}_{5} \mathrm{Cr}_{16} \mathrm{Cu}_{16} \mathrm{Fe}_{16} \mathrm{Ni}_{32} \mathrm{Cu}_{16}$}

This work by Gwalani et al. [108] is a very detailed investigation of the stability of the ordered $\mathrm{L}_{2}\left(\gamma^{\prime}\right)$ phase and a $\mathrm{Cu}$ rich phase in the multi-phase $\mathrm{CCAAl}_{5} \mathrm{Cr}_{16} \mathrm{Cu}_{16} \mathrm{Fe}_{16} \mathrm{Ni}_{32} \mathrm{Cu}_{16}$. It reveals the role of $\mathrm{Cu}$ on the stabilization and precipitation of $\gamma^{\prime}$ and on the formation of the $\mathrm{Cu}$ rich precipitates. The alloy was not homogenized but cold rolled and subsequently annealed at different temperatures. Even though several criteria of Table 2 are violated, it is possible to compare the different thermomechanical heat treatments amongst each other.

The authors determine the $\gamma^{\prime}$ formation temperature by synchrotron diffraction experiments to $930^{\circ} \mathrm{C}$. This is of high interest for all the investigations who use the $\gamma^{\prime}$ particles as precipitate strengthener.

As there is no information given regarding mechanical properties, there is no comparison possible to other alloys of this review.

\section{e) From $\mathrm{Al}_{8} \mathrm{Co}_{17} \mathrm{Cr}_{17} \mathrm{Cu}_{8} \mathrm{Fe}_{17} \mathrm{Ni}_{33}$ to $\mathrm{Al}_{10} \mathrm{Co}_{25} \mathrm{Cr}_{8} \mathrm{Fe}_{15} \mathrm{Ni}_{36} \mathrm{Ti}_{6}[28-30,86,89]$}

The authors have chosen the optimization path " $\mathrm{L} 1_{2}$ precipitates in an fcc" matrix as a result of year-long investigations of multi-phase CCA in the Al-Co-Cr-Cu-Fe-Ni-Ti family [28]. In the early years, the primary goal of our research was the discovery of a single phase HEA. The starting alloy was the, even at this time 
intensively investigated equiatomic alloy $\mathrm{AlCoCrCuFeNi}[47,100]$. There was no equilibrium state that allowed this alloy to be single phase and thus the composition was modified. A first reduction [29, 87] and a complete omission [33] of $\mathrm{Cu}$ reduced the number of phases but again there was no possibility for an equilibrium single phase in these bcc based alloys $\mathrm{Al}_{23} \mathrm{Co}_{15} \mathrm{Cr}_{23} \mathrm{Cu}_{8} \mathrm{Fe}_{15} \mathrm{Ni}_{16}$ and $\mathrm{AlCoCrFeNi}$ (see also Figure 1). Furthermore, these alloys were extremely brittle during handling, which lead to the decision of searching for fcc based alloys. The whole process has been described in detail in [89] and [28].

Several calculations with the ThermoCalc software [26] and the TTNi7 database [27] lead to the casting of the $\mathrm{Al}_{8} \mathrm{Co}_{17} \mathrm{Cr}_{17} \mathrm{Cu}_{8} \mathrm{Fe}_{17} \mathrm{Ni}_{33}$ alloy $[29,87]$. This CCA has a single fcc phase at temperatures $>950^{\circ} \mathrm{C}$. Quenching of this high temperature region shows that the alloy was indeed very ductile, but with a too low strength for application. At this point, the idea of using a single phase alloy was given up and a search for a strengthening second phase started. The $\mathrm{Al}_{8} \mathrm{Co}_{17} \mathrm{Cr}_{17} \mathrm{Cu}_{8} \mathrm{Fe}_{17} \mathrm{Ni}_{33}$ alloydoes provide such a strengthening phase, i.e. the $\mathrm{L} 1_{2}$ structured $\gamma^{\prime}$ phase. However, the $\mathrm{L} 1_{2}$ precipitates are quite small, with only $10-60 \mathrm{~nm}$ [29], their volume fraction is very low, i.e. only 6 vol.\%, and their effect on strengthening is not sufficient [86]. This is why known $\gamma^{\prime}$ strengtheners Mo, $\mathrm{W}$ and Ti in very small concentrations $(0.1,0.1$ and 1 at.\%) have been added to the alloy [88]. These amounts were still insufficient for strengthening, as can be seen by comparing the hardness data in Table 23 and Figure 7.

\begin{tabular}{|c|c|c|c|c|c|}
\hline Alloy & State & $\mathbf{L 1}_{2}$ size & $\begin{array}{l}\text { Vol. } \\
\%\end{array}$ & $\begin{array}{l}\text { HV0.05/ } \\
20\end{array}$ & Ref. \\
\hline $\mathrm{Al}_{8} \mathrm{Co}_{17} \mathrm{Cr}_{17} \mathrm{Cu}_{8} \mathrm{Fe}_{17} \mathrm{Ni}_{33}$ & as-cast & $\sim 10 \mathrm{~nm}$ & & $280 \pm 18$ & [88] \\
\hline $\mathrm{Al}_{8} \mathrm{Co}_{17} \mathrm{Cr}_{17} \mathrm{Cu}_{8} \mathrm{Fe}_{17} \mathrm{Ni}_{33}$ & $1250^{\circ} \mathrm{C} 1 \mathrm{~h}$ & - & & $168 \pm 5$ & [88] \\
\hline $\mathrm{Al}_{8} \mathrm{Co}_{17} \mathrm{Cr}_{17} \mathrm{Cu}_{8} \mathrm{Fe}_{17} \mathrm{Ni}_{33}$ & $\begin{array}{l}1250^{\circ} \mathrm{C} 1 \mathrm{~h}- \\
700^{\circ} \mathrm{C} 24 \mathrm{~h}\end{array}$ & $\sim 25 \mathrm{~nm}$ & & $328 \pm 7$ & {$[88]$} \\
\hline $\mathrm{Al}_{8} \mathrm{Co}_{17} \mathrm{Cr}_{17} \mathrm{Cu}_{8} \mathrm{Fe}_{17} \mathrm{Ni}_{33}$ & $\begin{array}{c}1250^{\circ} \mathrm{C} 1 \mathrm{~h}- \\
850^{\circ} \mathrm{C} 7 \mathrm{~h}\end{array}$ & $\sim 60 \mathrm{~nm}$ & $\sim 6$ & $206 \pm 5$ & $\begin{array}{l}\text { This } \\
\text { work }\end{array}$ \\
\hline $\mathrm{Al}_{8} \mathrm{Co}_{17} \mathrm{Cr}_{14} \mathrm{Cu}_{8} \mathrm{Fe}_{17} \mathrm{Ni}_{35} \mathrm{~W}_{0.1} \mathrm{Mo}_{0.1} \mathrm{Ti}_{1}$ & as-cast & $\sim 10 \mathrm{~nm}$ & & $231 \pm 12$ & {$[88]$} \\
\hline $\mathrm{Al}_{8} \mathrm{Co}_{17} \mathrm{Cr}_{14} \mathrm{Cu}_{8} \mathrm{Fe}_{17} \mathrm{Ni}_{35} \mathrm{~W}_{0.1} \mathrm{Mo}_{0.1} \mathrm{Ti}_{1}$ & $1250^{\circ} \mathrm{C} 1.3 \mathrm{~h}$ & $\sim 5 \mathrm{~nm}$ & & $178 \pm 7$ & {$[88]$} \\
\hline $\mathrm{Al}_{8} \mathrm{Co}_{17} \mathrm{Cr}_{14} \mathrm{Cu}_{8} \mathrm{Fe}_{17} \mathrm{Ni}_{35} \mathrm{~W}_{0.1} \mathrm{Mo}_{0.1} \mathrm{Ti}_{1}$ & $\begin{array}{c}1250^{\circ} \mathrm{C} 1.3 \mathrm{~h}- \\
700^{\circ} \mathrm{C} 24 \mathrm{~h}\end{array}$ & $\sim 30 \mathrm{~nm}$ & & $343 \pm 6$ & {$[88]$} \\
\hline $\mathrm{Al}_{8} \mathrm{Co}_{17} \mathrm{Cr}_{14} \mathrm{Cu}_{8} \mathrm{Fe}_{17} \mathrm{Ni}_{35} \mathrm{~W}_{0.1} \mathrm{Mo}_{0.1} \mathrm{Ti}_{1}$ & $\begin{array}{l}1250^{\circ} \mathrm{C} 1.3 \mathrm{~h}- \\
875^{\circ} \mathrm{C} 100 \mathrm{~h} \\
\end{array}$ & $\sim 140 \mathrm{~nm}$ & $\sim 14$ & $171 \pm 7$ & $\begin{array}{l}\text { This } \\
\text { work }\end{array}$ \\
\hline $\mathrm{Al}_{10} \mathrm{Co}_{25} \mathrm{Cr}_{8} \mathrm{Fe}_{15} \mathrm{Ni}_{36} \mathrm{Ti}_{6}$ & as-cast & $\sim 60 \mathrm{~nm}$ & 57 & $343 \pm 22$ & $\begin{array}{l}\text { [30] and } \\
\text { this work }\end{array}$ \\
\hline $\mathrm{Al}_{10} \mathrm{Co}_{25} \mathrm{Cr}_{8} \mathrm{Fe}_{15} \mathrm{Ni}_{36} \mathrm{Ti}_{6}$ & $1220^{\circ} \mathrm{C} 20 \mathrm{~h}$ & $\sim 14 \mathrm{~nm}$ & 32 & $341 \pm 12$ & $\begin{array}{l}{[30] \text { and }} \\
\text { this work }\end{array}$ \\
\hline $\mathrm{Al}_{10} \mathrm{Co}_{25} \mathrm{Cr}_{8} \mathrm{Fe}_{15} \mathrm{Ni}_{36} \mathrm{Ti}_{6}$ & $\begin{array}{l}1220^{\circ} \mathrm{C} 20 \mathrm{~h}- \\
900^{\circ} \mathrm{C} 5 \mathrm{~h}\end{array}$ & $\begin{array}{l}\sim 10 \& \\
\sim 370 \mathrm{~nm}\end{array}$ & 45 & $345 \pm 14$ & $\begin{array}{l}{[30] \text { and }} \\
\text { this work }\end{array}$ \\
\hline $\mathrm{Al}_{10} \mathrm{Co}_{25} \mathrm{Cr}_{8} \mathrm{Fe}_{15} \mathrm{Ni}_{36} \mathrm{Ti}_{6}$ & $\begin{array}{r}1220^{\circ} \mathrm{C} 20 \mathrm{~h}- \\
900^{\circ} \mathrm{C} 50 \mathrm{~h} \\
\end{array}$ & $\begin{aligned} & 10 \& \\
& \sim 320 \mathrm{~nm} \\
&\end{aligned}$ & 40 & $345 \pm 18$ & $\begin{array}{l}{[30] \text { and }} \\
\text { this work }\end{array}$ \\
\hline
\end{tabular}

Table 23: Hardness data (HV0.05) for three different, in most cases, two-phase CCA in different heat treatment conditions $[30,88]$

Thus a new search with ThermoCalc started and the $\mathrm{Al}_{10} \mathrm{Co}_{25} \mathrm{Cr}_{8} \mathrm{Fe}_{15} \mathrm{Ni}_{36} \mathrm{Ti}_{6}$ alloy was discovered $[28,89]$. This alloy has since then been the base for most research activities of this research group and is internally called the Daoud alloy. After finding the optimum homogenization $\left(1220^{\circ} \mathrm{C} 20 \mathrm{~h}\right)$, annealing $\left(900^{\circ} \mathrm{C} 50 \mathrm{~h}\right)$ parameters and cooling conditions (cooling in the furnace under Ar flow), the mechanical properties of this alloy has been compared with heat resistant steels and Ni-base superalloys [30].The results are very promising with some advantages over IN617 and alloy $800 \mathrm{H}$ in the temperature regime up to $1000^{\circ} \mathrm{C}$ in hot tension testing [30]. Currently, the optimization procedure is carried on by focussing on adding small amounts of interesting elements. 


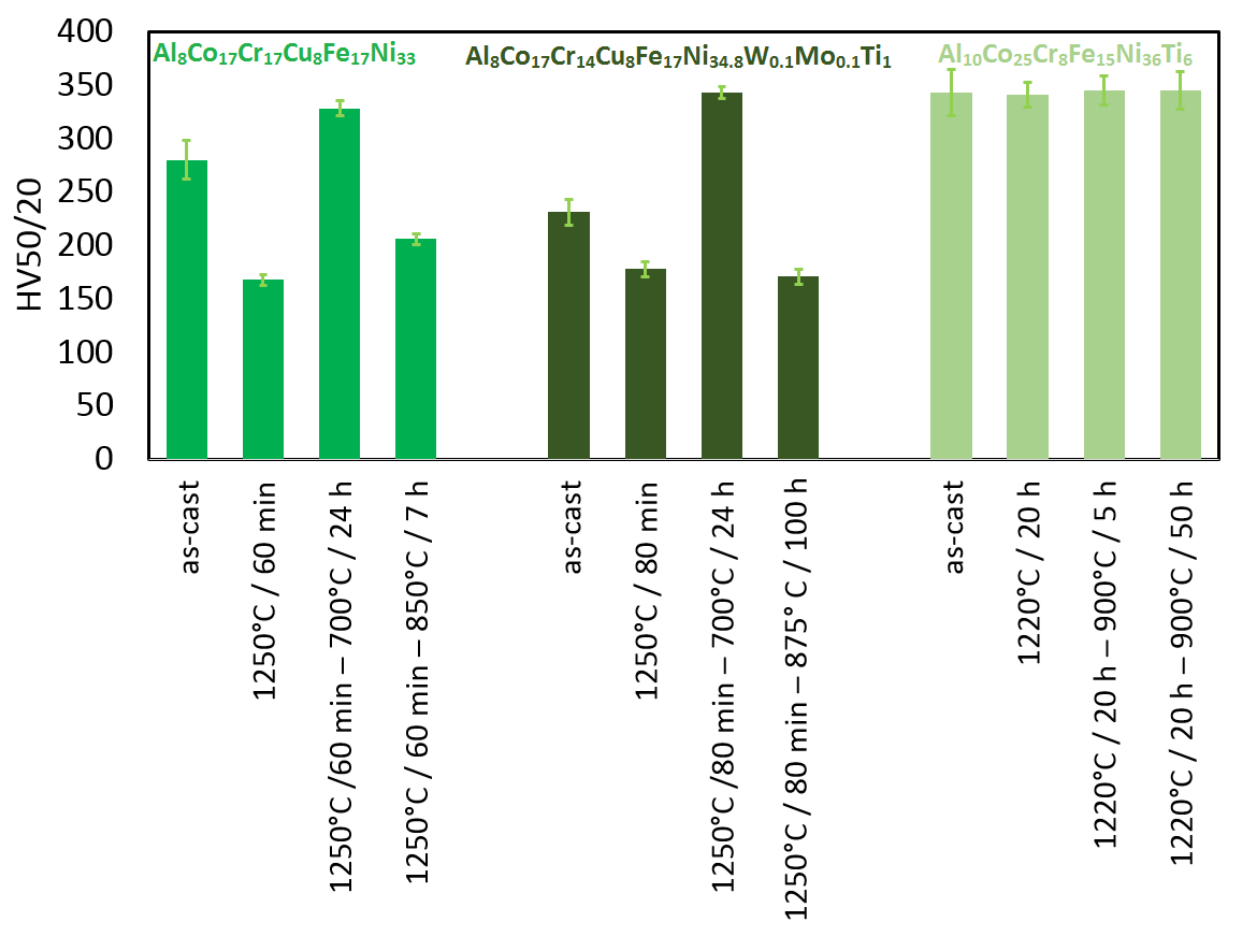

Figure 7: Vickers hardness HV0.05 for the alloys $\mathrm{Al}_{8} \mathrm{Co}_{17} \mathrm{Cr}_{17} \mathrm{Cu}_{8} \mathrm{Fe}_{17} \mathrm{Ni}_{33}, \mathrm{Al}_{8} \mathrm{Co}_{17} \mathrm{Cr}_{14} \mathrm{Cu}_{8} \mathrm{Fe}_{17} \mathrm{Ni}_{35} \mathrm{~W}_{0.1} \mathrm{Mo}_{0.1} \mathrm{Ti}_{1}$ and $\mathrm{Al}_{10} \mathrm{Co}_{25} \mathrm{Cr}_{8} \mathrm{Fe}_{15} \mathrm{Ni}_{36} \mathrm{Ti}_{6}$

The CCA, $\mathrm{Al}_{10} \mathrm{Co}_{25} \mathrm{Cr}_{8} \mathrm{Fe}_{15} \mathrm{Ni}_{36} \mathrm{Ti}_{6}$, in its optimum condition shows a three phase microstructure: few up to $100 \mu \mathrm{m}$ long Al-Ni rich needles of $\mathrm{C} 1$ type and many about $350 \mathrm{~nm}$ sized cuboidalL $1_{2}\left(\gamma^{\prime}\right)$ precipitates in an $\mathrm{fcc}(\gamma)$ matrix. The $\mathrm{L}_{2}$ volume fraction, being $32-57 \mathrm{vol} . \%$, is much higher than in the previous alloys. It is interesting to note that the hardness HV0.05 is the same in all states and thus independent of the size of the $\mathrm{L}_{2}$ precipitates. The tensile properties, however, do depend on the heat treatment, as can be seen in Table 24. The best tensile properties are obtained for the two-phase CCA $\mathrm{Al}_{10} \mathrm{Co}_{25} \mathrm{Cr}_{8} \mathrm{Fe}_{15} \mathrm{Ni}_{36} \mathrm{Ti}_{6}$ after homogenization $\left(1220^{\circ} \mathrm{C} 20 \mathrm{~h}\right)$ and subsequent annealing at $900^{\circ} \mathrm{C} 50 \mathrm{~h}$.

\begin{tabular}{|c|c|c|c|c|c|c|}
\hline Alloy & State & $\begin{array}{c}\text { Phases } \\
\text { detected }\end{array}$ & $\begin{array}{c}\mathcal{E}_{\mathrm{f}} \\
{[\%]}\end{array}$ & $\begin{array}{c}\text { YS } \\
{[\mathrm{MPa}]}\end{array}$ & $\begin{array}{c}\text { UTS } \\
\text { [MPa] }\end{array}$ & Ref. \\
\hline \multicolumn{7}{|c|}{ At room temperature } \\
\hline $\mathrm{Al}_{8} \mathrm{Co}_{17} \mathrm{Cr}_{17} \mathrm{Cu}_{8} \mathrm{Fe}_{17} \mathrm{Ni}_{33}$ & as-cast & $\mathrm{fcc}+\mathrm{L} 1_{2}$ & 9 & 357 & 459 & {$[88]$} \\
\hline $\mathrm{Al}_{8} \mathrm{Co}_{17} \mathrm{Cr}_{17} \mathrm{Cu}_{8} \mathrm{Fe}_{17} \mathrm{Ni}_{33}$ & $1150^{\circ} \mathrm{C} 5 \mathrm{~h}$ & $\mathrm{fcc}+\mathrm{L1}_{2}$ & 39 & 215 & 489 & [88] \\
\hline $\mathrm{Al}_{10} \mathrm{Co}_{25} \mathrm{Cr}_{8} \mathrm{Fe}_{15} \mathrm{Ni}_{36} \mathrm{Ti}_{6}$ & $\begin{array}{c}1220^{\circ} \mathrm{C} 20 \mathrm{~h}- \\
900^{\circ} \mathrm{C} 5 \mathrm{~h}\end{array}$ & $\mathrm{fcc}+\mathrm{L} 1_{2}+\mathrm{C} 1$ & 12 & 568 & 786 & $\begin{array}{l}\text { [30] and } \\
\text { this work }\end{array}$ \\
\hline $\mathrm{Al}_{10} \mathrm{Co}_{25} \mathrm{Cr}_{8} \mathrm{Fe}_{15} \mathrm{Ni}_{36} \mathrm{Ti}_{6}$ & $\begin{array}{c}1220^{\circ} \mathrm{C} 20 \mathrm{~h}- \\
900^{\circ} \mathrm{C} 50 \mathrm{~h} \\
\end{array}$ & $\begin{array}{c}\mathrm{fcc}+\mathrm{L}_{2}+ \\
\mathrm{C} 1 \\
\end{array}$ & 20 & 596 & 1039 & $\begin{array}{l}{[30] \text { and }} \\
\text { this work }\end{array}$ \\
\hline \multicolumn{7}{|c|}{ At $700^{\circ} \mathrm{C}$} \\
\hline $\mathrm{Al}_{10} \mathrm{Co}_{25} \mathrm{Cr}_{8} \mathrm{Fe}_{15} \mathrm{Ni}_{36} \mathrm{Ti}_{6}$ & $\begin{array}{c}1220^{\circ} \mathrm{C} 20 \mathrm{~h}- \\
900^{\circ} \mathrm{C} 5 \mathrm{~h}\end{array}$ & $\begin{array}{c}\mathrm{fcc}+\mathrm{L}_{1}+ \\
\mathrm{C} 1\end{array}$ & 18 & 487 & 702 & $\begin{array}{l}{[30] \text { and }} \\
\text { this work }\end{array}$ \\
\hline $\mathrm{Al}_{10} \mathrm{Co}_{25} \mathrm{Cr}_{8} \mathrm{Fe}_{15} \mathrm{Ni}_{36} \mathrm{Ti}_{6}$ & $\begin{array}{r}1220^{\circ} \mathrm{C} 20 \mathrm{~h}- \\
900^{\circ} \mathrm{C} 50 \mathrm{~h} \\
\end{array}$ & $\begin{array}{c}\mathrm{fcc}+\mathrm{L}_{1}+ \\
\mathrm{C} 1\end{array}$ & 11 & 486 & 624 & $\begin{array}{l}{[30] \text { and }} \\
\text { this work }\end{array}$ \\
\hline
\end{tabular}

Table 24: The yield strength (YS), ultimate tensile strength (UTS), and elongation to failure $\left(\varepsilon_{f}\right)$ in tension for different states of the $\mathrm{Al}_{8} \mathrm{Co}_{17} \mathrm{Cr}_{17} \mathrm{Cu}_{8} \mathrm{Fe}_{17} \mathrm{Ni}_{33}$ and $\mathrm{Al}_{10} \mathrm{Co}_{25} \mathrm{Cr}_{8} \mathrm{Fe}_{15} \mathrm{Ni}_{36} \mathrm{Ti}_{6} \mathrm{CCA}$ at room temperature and at $700^{\circ} \mathrm{C}$. 


\section{Overview and comparison of the tensile and compressive data of CCA}

This section summarizes the tensile data that has been obtained in different CCA, some HEA and some commercial alloys for comparison. Most of the literature data for multi-phase CCA do not fulfil the criteria summarized in Table 2. However, the collected data gives an idea about the mechanical properties achieved so far. It is expected that a proper heat treatment will improve the mechanical properties in some cases even further. It must also be noted that the deformation rate has not been taken into account. It is expected that the result especially at high temperatures are influenced strongly by the rate of deformation (creep testing will be necessary).

\subsection{Compressive properties at room temperature}

A comparison of the compressive data in some CCA and HEA is given in Table 25 and Figure 8. The best results are obtained for the alloys with eutectic-like microstructure and the alloys with the strengthening $\mu$ phase. The eutectic alloys, however, do not fulfil the criteria regarding composition (Table 2), since they are using only four elements. Unfortunately, there is no compression data on five (or more) element eutecticlike CCA. Despite that, this group is especially interesting in comparing compression testing data, because these alloys can be used in the as-cast state.

It is interesting to note that in none of the works the alloys have been sufficiently homogenized.

\begin{tabular}{|c|c|c|c|c|c|c|}
\hline Alloy & $\begin{array}{l}\text { Specimen } \\
\text { state }\end{array}$ & $\begin{array}{c}\text { Major } \\
\text { Detected } \\
\text { Phases } \\
\end{array}$ & $\begin{array}{l}\text { Compres- } \\
\text { sive } \varepsilon_{\mathrm{f}}[\%]\end{array}$ & $\begin{array}{c}\text { Compres- } \\
\text { sive YS } \\
{[\mathrm{MPa}]} \\
\end{array}$ & $\begin{array}{c}\sigma_{\mathbf{f}} \\
{[\mathbf{M P a}]}\end{array}$ & Ref. \\
\hline \multicolumn{7}{|c|}{ Alloys with eutectic-like microstructure } \\
\hline $\mathrm{Al}_{23} \mathrm{Cr}_{26} \mathrm{Fe}_{26} \mathrm{Ni}_{26}$ & as-cast & $\mathrm{bcc}+\mathrm{B} 2$ & -37.1 & 770.0 & 3002 & {$[75]$} \\
\hline $\begin{array}{c}\text { equiatomic } \\
\mathrm{Al}_{25} \mathrm{Cr}_{25} \mathrm{Fe}_{25} \mathrm{Ni}_{25}\end{array}$ & as-cast & $\mathrm{bcc}+\mathrm{B} 2$ & -34.6 & 843.2 & 3450 & {$[75]$} \\
\hline $\mathrm{Al}_{27} \mathrm{Cr}_{24} \mathrm{Fe}_{24} \mathrm{Ni}_{24}$ & as-cast & $\mathrm{bcc}+\mathrm{B} 2$ & -27.1 & 1044.0 & 3513 & {$[75]$} \\
\hline $\mathrm{Al}_{29} \mathrm{Cr}_{24} \mathrm{Fe}_{24} \mathrm{Ni}_{24}$ & as-cast & $\mathrm{bcc}+\mathrm{B} 2$ & -31.4 & 906.8 & 3608 & {$[75]$} \\
\hline $\mathrm{Al}_{30} \mathrm{Cr}_{23} \mathrm{Fe}_{23} \mathrm{Ni}_{23}$ & as-cast & $\mathrm{bcc}+\mathrm{B} 2$ & -24.7 & 1122.8 & 3705 & {$[75]$} \\
\hline $\mathrm{Al}_{17} \mathrm{Cr}_{17} \mathrm{Fe}_{34} \mathrm{Ni}_{34}$ & as-cast & $\mathrm{bcc}+\mathrm{B} 2$ & -17 & & 1228 & [73] \\
\hline \multicolumn{7}{|c|}{ bcc matrix, different additional phases } \\
\hline equiatomic $\mathrm{AlCoCrFeNi}$ & as-cast & $\mathrm{bcc}+\mathrm{B} 2$ & -22.7 & & 2865 & [109] \\
\hline $\mathrm{Al}_{18} \mathrm{Cr}_{18} \mathrm{Fe}_{17} \mathrm{Ni}_{33} \mathrm{Ti}_{9}$ & as-cast & $\begin{array}{l}\mathrm{bcc}+\mathrm{B} 2+ \\
\quad \mathrm{L}_{2}\end{array}$ & -16.3 & & 2083 & {$[53]$} \\
\hline $\mathrm{Al}_{18} \mathrm{Cr}_{18} \mathrm{Fe}_{17} \mathrm{Ni}_{33} \mathrm{Ti}_{9}$ & $1000^{\circ} \mathrm{C} 6 \mathrm{~h}$ & $\begin{array}{l}\mathrm{bcc}+\mathrm{B} 2+ \\
\quad \mathrm{L}_{2}\end{array}$ & -19.8 & & 2680 & {$[53]$} \\
\hline $\mathrm{Al}_{24} \mathrm{Cr}_{24} \mathrm{Fe}_{24} \mathrm{Mo}_{5} \mathrm{Ni}_{24}$ & as-cast & $\mathrm{bcc}+\mathrm{B} 2$ & -28.7 & & 3222 & [49] \\
\hline $\mathrm{Cr}_{22} \mathrm{Fe}_{22} \mathrm{Ni}_{22} \mathrm{~V}_{11} \mathrm{~W}_{22}$ & as-cast & $\mathrm{bcc}+\mathrm{fcc}+\sigma$ & -7.3 & & 2240 & {$[50]$} \\
\hline $\mathrm{Al}_{12} \mathrm{Cr}_{18} \mathrm{Co}_{18} \mathrm{Fe}_{36} \mathrm{Ni}_{18}$ & as-cast & $\mathrm{bcc}+\mathrm{B} 2$ & -30.2 & 1166 & 1945 & {$[77]$} \\
\hline \multicolumn{7}{|c|}{ fcc matrix, different additional phases } \\
\hline equiatomic $\mathrm{CoCrCuFeNi}$ & as-cast & $\mathrm{fcc}+\mathrm{fcc}$ & -50.2 & & 888 & {$[48]$} \\
\hline $\mathrm{Al}_{17} \mathrm{Cr}_{17} \mathrm{Cu}_{17} \mathrm{Fe}_{17} \mathrm{Ni}_{33}$ & as-cast & $\mathrm{fcc}+\mathrm{bcc}+\mathrm{B} 2$ & -30 & & 2123 & [110] \\
\hline \multicolumn{7}{|c|}{$\sigma$ in $f c c$} \\
\hline equiatomic CoCrFeMnNi & $1100^{\circ} \mathrm{C} 24 \mathrm{~h}$ & fcc & -75 & 230 & 1400 & {$[96]$} \\
\hline $\mathrm{Co}_{19} \mathrm{Cr}_{19} \mathrm{Fe}_{19} \mathrm{Mn}_{19} \mathrm{Ni}_{19} \mathrm{~V}_{5}$ & $1100^{\circ} \mathrm{C} 24 \mathrm{~h}$ & $\mathrm{fcc}+\sigma$ & -75 & 200 & 1400 & [96] \\
\hline $\mathrm{Co}_{18} \mathrm{Cr}_{18} \mathrm{Fe}_{18} \mathrm{Mn}_{18} \mathrm{Ni}_{18} \mathrm{~V}_{9}$ & $1100^{\circ} \mathrm{C} 24 \mathrm{~h}$ & fcc $+\sigma$ & -75 & 620 & 1500 & [96] \\
\hline $\mathrm{Co}_{17} \mathrm{Cr}_{17} \mathrm{Fe}_{17} \mathrm{Mn}_{17} \mathrm{Ni}_{17} \mathrm{~V}_{13}$ & $1100^{\circ} \mathrm{C} 24 \mathrm{~h}$ & $f c c+\sigma$ & -7.8 & 740 & 1325 & [96] \\
\hline $\begin{array}{c}\text { equiatomic } \\
\text { CoCrFeMnNiV }\end{array}$ & $1100^{\circ} \mathrm{C} 24 \mathrm{~h}$ & $\mathrm{fcc}+\sigma$ & -0.5 & 1660 & 1845 & {$[96]$} \\
\hline \multicolumn{7}{|c|}{ single phase HEA } \\
\hline $\mathrm{Al}_{7} \mathrm{Co}_{23} \mathrm{Cr}_{23} \mathrm{Fe}_{23} \mathrm{Ni}_{23}$ & as-cast & $\mathrm{fcc}$ & -25 & & 2000 & [111] \\
\hline equiatomic $\mathrm{CoCrFeNi}$ & as-cast & fcc & -83 & & 488 & [112] \\
\hline
\end{tabular}


Table 25: Compressive properties and major crystal structures of some typical CCA at room temperature. Compressive elongation to failure $\left(\varepsilon_{f}\right)$, yield strength $(Y S)$, compressive fracture strength $\left(\sigma_{f}\right)$

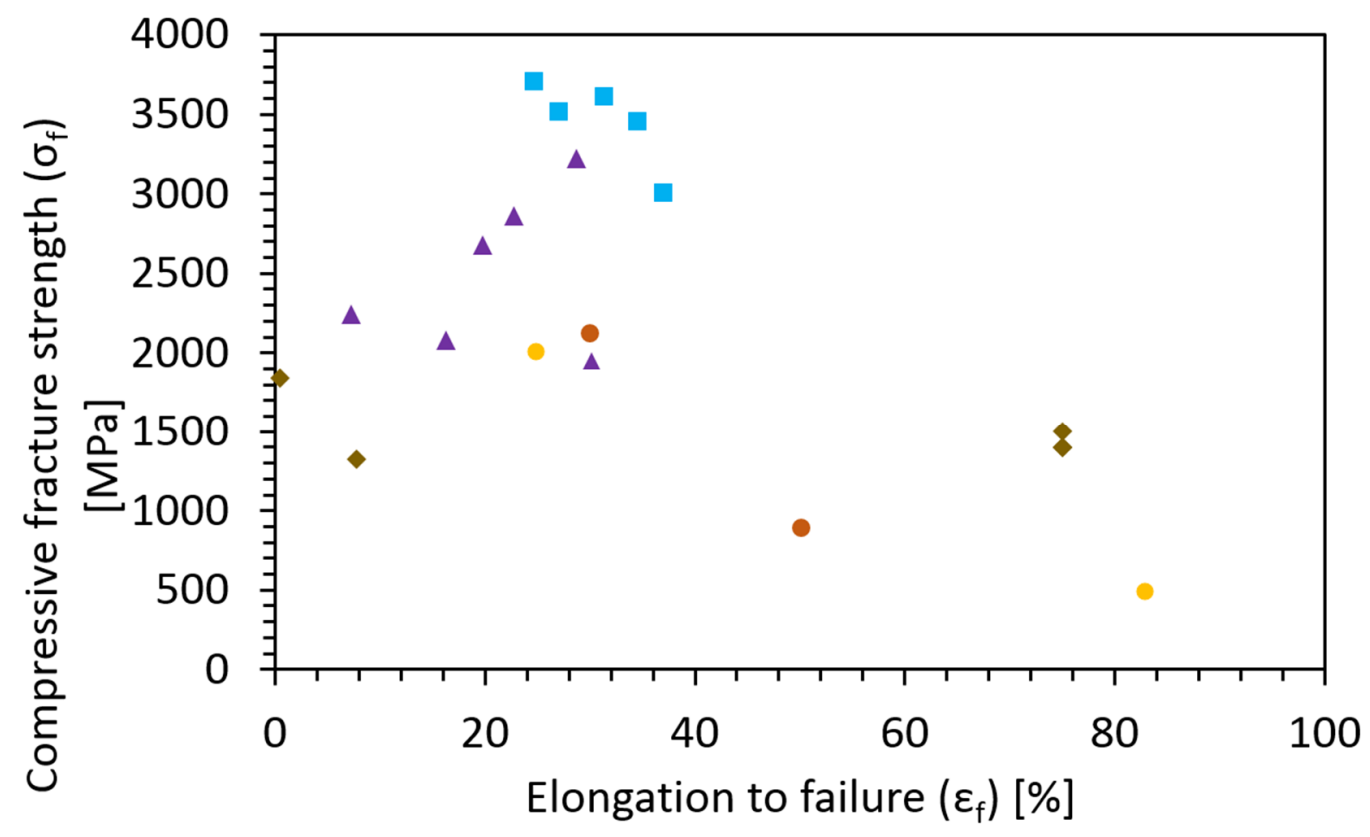

Figure 8: Graphic representation of the $\sigma_{\mathrm{f}}$ versus compressive $\varepsilon_{\mathrm{f}}$ of the alloys summarized in Table 25 . alloys with eutectic-like microstructure, ${ }^{\mathrm{fcc}}$ matrix, different additional phases, $\boldsymbol{\nu}$ in $\mathrm{fcc}, \boldsymbol{\Delta} \mathrm{bcc}$ matrix, different additional phases, single phase alloys

The values of the $\sigma_{\text {fare }}$ about three times higher than the UTS values. However, regarding application tension data are essential. Especially for some of the eutectic-like microstructures the samples are too brittle to obtain larger geometries or to machine tension samples and to test them in a tension experiment. Therefore, the more meaningful tension data will be presented in the following chapter. 
4.2 Tensile properties at room temperature:

\begin{tabular}{|c|c|c|c|c|c|c|c|}
\hline Alloy & $\begin{array}{l}\text { Specimen } \\
\text { State }\end{array}$ & $\begin{array}{c}\text { Phases } \\
\text { detected, } \\
\text { matrix } \\
\text { mentioned } \\
\text { first } \\
\end{array}$ & $\begin{array}{c}\varepsilon_{\mathbf{f}} \\
{[\%]}\end{array}$ & $\begin{array}{c}\text { YS } \\
{[\mathbf{M P a}]}\end{array}$ & $\begin{array}{c}\text { UTS } \\
\text { [MPa] }\end{array}$ & Ref. & Comment \\
\hline \multicolumn{8}{|c|}{ Alloys with eutectic microstructure } \\
\hline $\mathrm{Al}_{17} \mathrm{Cr}_{17} \mathrm{Fe}_{33} \mathrm{Ni}_{33}$ & as-cast & $\begin{array}{c}\mathrm{fcc}+\mathrm{bcc}+ \\
\mathrm{B} 2\end{array}$ & 17 & 780 & 1228 & [73] & no eq. \\
\hline equiatomic $\mathrm{AlCoCrFeNi}$ & as-cast & $\mathrm{bcc}+\mathrm{B} 2$ & 1 & 395 & 400 & {$[72]$} & no hom. \\
\hline equiatomic $\mathrm{AlCoCrFeNi}$ & $1000^{\circ} \mathrm{C} 6 \mathrm{~h}$ & $\mathrm{bcc}+\mathrm{fcc}$ & 0.8 & $\sim 900$ & 935 & [71] & \\
\hline $\mathrm{Al}_{17} \mathrm{Cr}_{17} \mathrm{Co}_{17} \mathrm{Fe}_{17} \mathrm{Ni}_{33.3}$ & as-cast & $\mathrm{fcc}+\mathrm{B} 2$ & 16.5 & 545 & 1030 & [74] & no hom. \\
\hline $\mathrm{Al}_{16} \mathrm{Cr}_{16} \mathrm{Co}_{16} \mathrm{Fe}_{16} \mathrm{Ni}_{34.4}$ & as-cast & $\mathrm{fcc}+\mathrm{B} 2$ & 16.5 & 545 & 1050 & [74] & no hom. \\
\hline $\mathrm{Al}_{16} \mathrm{Cr}_{16} \mathrm{Co}_{16} \mathrm{Fe}_{16} \mathrm{Ni}_{35.5}$ & as-cast & $\mathrm{fcc}+\mathrm{B} 2$ & 20 & 545 & 1110 & [74] & no hom. \\
\hline \multicolumn{8}{|c|}{ L12 in fcc (with possible third phase) } \\
\hline$\underline{\mathrm{Al}_{4}} \underline{\mathrm{Co}_{19}} \underline{\mathrm{Cr}_{19}} \underline{\mathrm{Cu}_{4}} \underline{\mathrm{Fe}_{19}} \underline{\mathrm{Ni}_{37}}$ & $\begin{array}{c}1200^{\circ} \mathrm{C} 24 \mathrm{~h}- \\
\mathrm{cr}- \\
700^{\circ} \mathrm{C} 20 \mathrm{~h}\end{array}$ & fcc & $\sim 30$ & 719 & 1048 & {$[76]$} & no eq. \\
\hline $\mathrm{Al}_{4} \mathrm{Co}_{19} \mathrm{Cr}_{19} \mathrm{Cu}_{4} \mathrm{Fe}_{19} \mathrm{Ni}_{37}$ & $\begin{array}{c}1200^{\circ} \mathrm{C} 24 \mathrm{~h}- \\
\mathrm{cr}- \\
800^{\circ} \mathrm{C} 1 \mathrm{~h}\end{array}$ & $\mathrm{fcc}+\mathrm{Ll}_{2}$ & $\sim 32$ & 460 & 732 & [76] & no eq. \\
\hline $\mathrm{Al}_{10} \mathrm{Co}_{25} \mathrm{Cr}_{8} \mathrm{Fe}_{15} \mathrm{Ni}_{36} \mathrm{Ti}_{6}$ & $\begin{array}{c}1220^{\circ} \mathrm{C} 20 \mathrm{~h}- \\
900^{\circ} \mathrm{C} 5 \mathrm{~h}\end{array}$ & $\begin{array}{c}\mathrm{fcc}+\mathrm{L}_{2}+ \\
\mathrm{C} 1\end{array}$ & 12 & 568 & 786 & {$[30]$} & \\
\hline $\mathrm{Al}_{10} \mathrm{Co}_{25} \mathrm{Cr}_{8} \mathrm{Fe}_{15} \mathrm{Ni}_{36} \mathrm{Ti}_{6}$ & $\begin{array}{c}1220^{\circ} \mathrm{C} 20 \mathrm{~h}- \\
900^{\circ} \mathrm{C} 50 \mathrm{~h}\end{array}$ & $\begin{array}{c}\mathrm{fcc}+\mathrm{Ll}_{2}+ \\
\mathrm{C} 1\end{array}$ & 20 & 596 & 1039 & {$[30]$} & \\
\hline $\mathrm{Al}_{8} \mathrm{Co}_{17} \mathrm{Cr}_{17} \mathrm{Cu}_{8} \mathrm{Fe}_{17} \mathrm{Ni}_{33}$ & as-cast & $\begin{array}{c}\mathrm{fcc}+\mathrm{Ll}_{2}+ \\
\mathrm{Cr}_{23} \mathrm{C}_{6}\end{array}$ & 9 & 357 & 459 & {$[86]$} & no hom. \\
\hline $\mathrm{Al}_{8} \mathrm{Co}_{17} \mathrm{Cr}_{17} \mathrm{Cu}_{8} \mathrm{Fe}_{17} \mathrm{Ni}_{33}$ & $700^{\circ} \mathrm{C} 5 \mathrm{~h}$ & $\begin{array}{c}\mathrm{fcc}+\mathrm{Ll}_{2}+ \\
\mathrm{Cr}_{23} \mathrm{C}_{6}\end{array}$ & 0.1 & 365 & 365 & {$[86]$} & no hom. \\
\hline $\mathrm{Al}_{8} \mathrm{Co}_{17} \mathrm{Cr}_{17} \mathrm{Cu}_{8} \mathrm{Fe}_{17} \mathrm{Ni}_{33}$ & $1150^{\circ} \mathrm{C} 5 \mathrm{~h}$ & $\mathrm{fcc}+\mathrm{L1}_{2}(?)$ & 39 & 215 & 489 & {$[86]$} & no hom. \\
\hline equiatomic $\mathrm{CoCrFeNi}$ & $1200^{\circ} \mathrm{C} 4 \mathrm{~h}$ & fcc & 70 & $\sim 190$ & 453 & {$[78]$} & $\begin{array}{l}\text { composition } \\
\text { out of limits }\end{array}$ \\
\hline $\mathrm{Al}_{4} \mathrm{Co}_{24} \mathrm{Cr}_{24} \mathrm{Fe}_{24} \mathrm{Ni}_{24}$ & $1200^{\circ} \mathrm{C} 4 \mathrm{~h}$ & fcc & 70 & $\sim 210$ & 503 & {$[78]$} & $\begin{array}{l}\text { composition } \\
\text { out of limits }\end{array}$ \\
\hline $\mathrm{Al}_{4} \mathrm{Co}_{24} \mathrm{Cr}_{24} \mathrm{Fe}_{24} \mathrm{Ni}_{24}$ & $\begin{array}{c}1200^{\circ} \mathrm{C} 4 \mathrm{~h}- \\
\mathrm{cr}-1000^{\circ} \mathrm{C} / \\
2 \mathrm{~h}-800^{\circ} \mathrm{C} \\
18 \mathrm{~h}-\mathrm{wq}(\mathrm{P} 1)\end{array}$ & $\begin{array}{c}\mathrm{fcc}+\mathrm{L}_{2}+ \\
\mathrm{L} 2_{1}\end{array}$ & 39 & 645 & 1094 & {$[78]$} & no eq. \\
\hline $\mathrm{Al}_{4} \mathrm{Co}_{24} \mathrm{Cr}_{24} \mathrm{Fe}_{24} \mathrm{Ni}_{24}$ & $\begin{array}{c}1200^{\circ} \mathrm{C} 4 \mathrm{~h}- \\
\mathrm{cr}-700^{\circ} \mathrm{C} 4 \\
\mathrm{~h}-\mathrm{wq}(\mathrm{P} 2)\end{array}$ & $\begin{array}{c}\mathrm{fcc}+\mathrm{L}_{2}+ \\
\mathrm{L} 2_{1}\end{array}$ & 17 & 1005 & 1273 & {$[78]$} & no eq. \\
\hline \multicolumn{8}{|c|}{ Carbides in fcc } \\
\hline$\underline{\text { equiatomic } \mathrm{CoCrFeMnNi}}$ & $\begin{array}{l}\text { forged } 700^{\circ} \mathrm{C} \\
-1000^{\circ} \mathrm{C} 6 \mathrm{~h} \\
\text { forged } 700^{\circ} \mathrm{C}\end{array}$ & fcc & 50 & 243 & 558 & {$[38]$} & no eq. \\
\hline equiatomic $\mathrm{CoCrFeMnNi}$ & $\begin{array}{c}-1000^{\circ} \mathrm{C} 6 \mathrm{~h} \\
-\mathrm{cr}-900^{\circ} \mathrm{C} 6 \\
\mathrm{~h}\end{array}$ & fcc & 41 & 249 & 621 & {$[38]$} & no eq. \\
\hline $\mathrm{Co}_{17} \mathrm{Cr}_{17} \mathrm{Fe}_{17} \mathrm{Mn}_{17} \mathrm{Ni}_{17} \mathrm{C}_{2}$ & $\begin{array}{l}\text { forged } 700^{\circ} \mathrm{C} \\
-1000^{\circ} \mathrm{C} 6 \mathrm{~h} \\
\text { forged } 700^{\circ} \mathrm{C}\end{array}$ & $\begin{array}{c}\text { fcc }+ \\
\text { Carbide }\end{array}$ & 15 & 446 & 723 & {$[38]$} & no eq. \\
\hline $\mathrm{Co}_{17} \mathrm{Cr}_{17} \mathrm{Fe}_{17} \mathrm{Mn}_{17} \mathrm{Ni}_{17} \mathrm{C}_{2}$ & $\begin{array}{c}-1000^{\circ} \mathrm{C} / 6 \mathrm{~h} \\
-\mathrm{cr}-900^{\circ} \mathrm{C} 6 \\
\mathrm{~h}\end{array}$ & $\begin{array}{c}\text { fcc }+ \\
\text { Carbide }\end{array}$ & 28 & 581 & 857 & {$[38]$} & no eq. \\
\hline \multicolumn{8}{|c|}{ Two phase fcc + hcp } \\
\hline
\end{tabular}




\begin{tabular}{|c|c|c|c|c|c|c|c|}
\hline equiatomic $\mathrm{CoCrFeMnNi}$ & $\begin{array}{l}1200^{\circ} \mathrm{C} 48 \mathrm{~h}- \\
\mathrm{cr}-800^{\circ} \mathrm{C} 1 \mathrm{~h}\end{array}$ & fcc & 56 & 370 & 670 & {$[8]$} & no eq. \\
\hline $\mathrm{Co}_{10} \mathrm{Cr}_{10} \mathrm{Fe}_{50} \mathrm{Mn}_{30}$ & $1200^{\circ} \mathrm{C} 2 \mathrm{~h}$ & fcc + hcp & 50 & 250 & 730 & {$[18]$} & \\
\hline $\mathrm{Co}_{10} \mathrm{Cr}_{10} \mathrm{Fe}_{50} \mathrm{Mn}_{30}$ & $\begin{array}{c}\mathrm{cr}-900^{\circ} \mathrm{C} 3 \\
\min \end{array}$ & fcc + hcp & 75 & 330 & 870 & {$[18]$} & no eq. \\
\hline $\mathrm{Co}_{10} \mathrm{Cr}_{10} \mathrm{Fe}_{50} \mathrm{Mn}_{30}$ & $\begin{array}{c}1200^{\circ} \mathrm{C} 2 \mathrm{~h}- \\
\mathrm{cr}-900^{\circ} \mathrm{C} 5 \\
\min \end{array}$ & fcc + hcp & 65 & 280 & 800 & [18] & no eq. \\
\hline $\mathrm{Co}_{10} \mathrm{Cr}_{10} \mathrm{Fe}_{50} \mathrm{Mn}_{30}$ & $\begin{array}{c}1200^{\circ} \mathrm{C} 2 \mathrm{~h}- \\
\mathrm{cr}-900^{\circ} \mathrm{C} 30 \\
\min \end{array}$ & fcc + hcp & 63 & 350 & 830 & {$[18]$} & no eq. \\
\hline $\mathrm{Co}_{10} \mathrm{Cr}_{10} \mathrm{Fe}_{50} \mathrm{Mn}_{30}$ & $\begin{array}{c}\text { hot rolling - } \\
1200^{\circ} \mathrm{C} 5 \mathrm{~h}- \\
\text { friction stirred } \\
350 \mathrm{rpm} \\
\text { hot rolling - } \\
1200^{\circ} \mathrm{C} 5 \mathrm{~h}- \\
\text { friction stirred } \\
650 \mathrm{rpm} \\
\end{array}$ & fcc + hcp & 45 & 298 & 1400 & [34] & no eq. \\
\hline \multicolumn{8}{|c|}{ Special alloy $\mathrm{Al}_{7} \mathrm{Co}_{23} \mathrm{Cr}_{23} \mathrm{Fe}_{23} \mathrm{Ni}_{23}$} \\
\hline $\mathrm{Al}_{7} \mathrm{Co}_{23} \mathrm{Cr}_{23} \mathrm{Fe}_{23} \mathrm{Ni}_{23}$ & $\begin{array}{c}1100^{\circ} \mathrm{C} 48 \mathrm{~h}- \\
\mathrm{cr}- \\
800^{\circ} \mathrm{C} / 1 \mathrm{~h}\end{array}$ & $\mathrm{fcc}+\mathrm{B} 2$ & 48 & 860 & 1050 & [60] & no eq. \\
\hline $\mathrm{Al}_{7} \mathrm{Co}_{23} \mathrm{Cr}_{23} \mathrm{Fe}_{23} \mathrm{Ni}_{23}$ & $\begin{array}{c}1100^{\circ} \mathrm{C} 48 \mathrm{~h}- \\
\mathrm{cr}- \\
900^{\circ} \mathrm{C} / 1 \mathrm{~h}\end{array}$ & $\mathrm{fcc}+\mathrm{B} 2$ & 51 & 690 & 930 & {$[60]$} & no eq. \\
\hline $\mathrm{Al}_{7} \mathrm{Co}_{23} \mathrm{Cr}_{23} \mathrm{Fe}_{23} \mathrm{Ni}_{23}$ & $\begin{array}{c}1100^{\circ} \mathrm{C} 48 \mathrm{~h}- \\
\mathrm{cr}- \\
1000^{\circ} \mathrm{C} 1 \mathrm{~h}\end{array}$ & $\mathrm{fcc}+\mathrm{B} 2$ & 64 & 550 & 800 & {$[60]$} & no eq. \\
\hline $\mathrm{Al}_{7} \mathrm{Co}_{23} \mathrm{Cr}_{23} \mathrm{Fe}_{23} \mathrm{Ni}_{23}$ & $\begin{array}{c}1100^{\circ} \mathrm{C} 48 \mathrm{~h}- \\
\mathrm{cr}- \\
1100^{\circ} \mathrm{C} 1 \mathrm{~h}\end{array}$ & fcc & 87 & 260 & 620 & {$[60]$} & no eq. \\
\hline $\mathrm{Al}_{7} \mathrm{Co}_{23} \mathrm{Cr}_{23} \mathrm{Fe}_{23} \mathrm{Ni}_{23}$ & $\underset{\mathrm{h}}{\mathrm{cr}-1150^{\circ} \mathrm{C} 1}$ & fcc & 65 & 159 & 410 & [39] & no eq. \\
\hline $\mathrm{Al}_{7} \mathrm{Co}_{23} \mathrm{Cr}_{23} \mathrm{Fe}_{23} \mathrm{Ni}_{23}$ & $\begin{array}{c}\mathrm{cr}-1150^{\circ} \mathrm{C} 1 \\
\mathrm{~h}- \\
700^{\circ} / 50 \mathrm{~h}\end{array}$ & $\mathrm{fcc}+\mathrm{B} 2$ & 43 & 215 & 520 & [39] & no eq. \\
\hline $\mathrm{Al}_{7} \mathrm{Co}_{23} \mathrm{Cr}_{23} \mathrm{Fe}_{23} \mathrm{Ni}_{23}$ & $\begin{array}{c}\mathrm{cr}-1150^{\circ} \mathrm{C} 1 \\
\mathrm{~h}- \\
550^{\circ} 150 \mathrm{~h}\end{array}$ & $\mathrm{fcc}+\mathrm{L1}_{2}$ & 55 & 285 & 540 & [39] & no eq. \\
\hline $\mathrm{Al}_{7} \mathrm{Co}_{23} \mathrm{Cr}_{23} \mathrm{Fe}_{23} \mathrm{Ni}_{23}$ & $\underset{\min }{\mathrm{cr}-1150^{\circ} \mathrm{C} 2}$ & fcc & 60 & 263 & 589 & [39] & no eq. \\
\hline $\mathrm{Al}_{7} \mathrm{Co}_{23} \mathrm{Cr}_{23} \mathrm{Fe}_{23} \mathrm{Ni}_{23}$ & $\begin{array}{c}\mathrm{cr}-1150{ }^{\circ} \mathrm{C} 2 \\
\min - \\
650^{\circ} \mathrm{C} 50 \mathrm{~h}\end{array}$ & $\begin{array}{c}\mathrm{fcc}+\mathrm{L}_{2}+ \\
\mathrm{B} 2\end{array}$ & 45 & 490 & 840 & [39] & no eq. \\
\hline $\mathrm{Al}_{7} \mathrm{Co}_{23} \mathrm{Cr}_{23} \mathrm{Fe}_{23} \mathrm{Ni}_{23}$ & as-cast & $\mathrm{fcc}+\mathrm{L1}_{2}$ & $\sim 58$ & $\sim 175$ & $\sim 335$ & {$[62]$} & no eq. \\
\hline $\mathrm{Al}_{7} \mathrm{Co}_{23} \mathrm{Cr}_{23} \mathrm{Fe}_{23} \mathrm{Ni}_{23}$ & $700^{\circ} \mathrm{C} 72 \mathrm{~h}$ & $\mathrm{fcc}+\mathrm{L1}_{2}$ & $\sim 44$ & $\sim 305$ & $\sim 525$ & [62] & no eq. \\
\hline $\mathrm{Al}_{7} \mathrm{Co}_{23} \mathrm{Cr}_{23} \mathrm{Fe}_{23} \mathrm{Ni}_{23}$ & $900^{\circ} \mathrm{C} 72 \mathrm{~h}$ & $\mathrm{fcc}+\mathrm{bcc}$ & $\sim 44$ & $\sim 280$ & $\sim 570$ & [62] & no eq. \\
\hline \multicolumn{8}{|c|}{ B2 in bcc } \\
\hline $\mathrm{Al}_{12} \mathrm{Cr}_{18} \mathrm{Co}_{18} \mathrm{Fe}_{36} \mathrm{Ni}_{18}$ & as-cast & $\mathrm{bcc}+\mathrm{B} 2$ & 7.9 & 866 & 1223 & [77] & no hom. \\
\hline \multicolumn{8}{|c|}{$\sigma$ or $\mu$ in $f c c$} \\
\hline $\mathrm{Co}_{35} \mathrm{Cr}_{15} \mathrm{Fe}_{20} \mathrm{Mo}_{10} \mathrm{Ni}_{20}$ & $1200^{\circ} \mathrm{C} 48 \mathrm{~h}$ & fcc & 21.9 & 350 & 720 & {$[85]$} & \\
\hline $\mathrm{Co}_{35} \mathrm{Cr}_{15} \mathrm{Fe}_{20} \mathrm{Mo}_{10} \mathrm{Ni}_{20}$ & $\begin{array}{c}1200^{\circ} \mathrm{C} 48 \mathrm{~h}- \\
\mathrm{hr} 1100^{\circ} \mathrm{C}- \\
\mathrm{cr}- \\
800^{\circ} \mathrm{C} 1 \mathrm{~h} / \mathrm{AC}\end{array}$ & $\mathrm{fcc}+\mu$ & 12.1 & 1311 & 1410 & {$[85]$} & no eq. \\
\hline
\end{tabular}




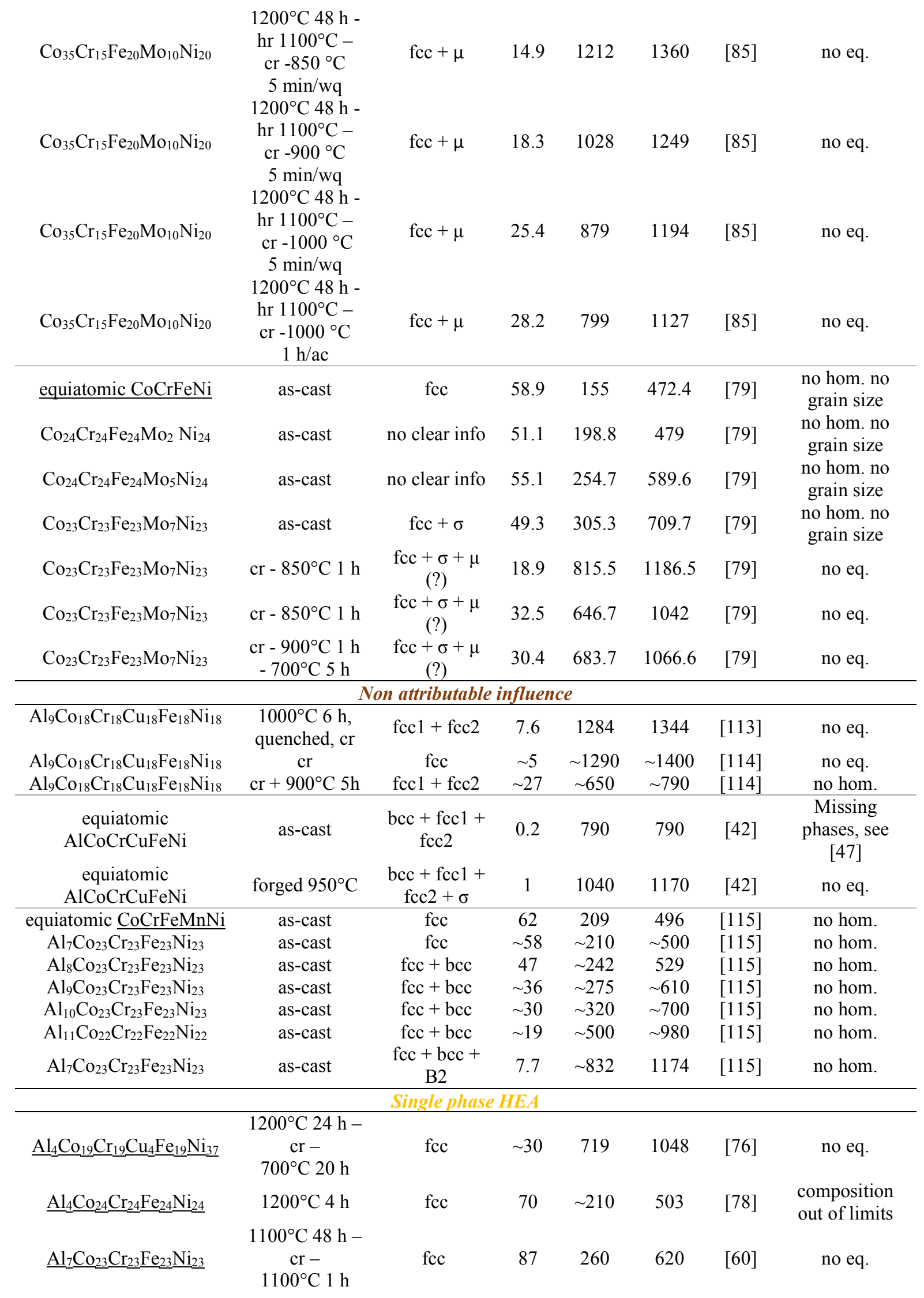




\begin{tabular}{|c|c|c|c|c|c|c|c|}
\hline$\underline{\mathrm{Al}_{7}} \underline{\mathrm{Co}}_{23} \underline{\mathrm{Cr}_{23}} \underline{\mathrm{Fe}_{23}} \underline{\mathrm{Ni}_{23}}$ & $\underset{\mathrm{h}}{\mathrm{cr}-1150^{\circ} \mathrm{C} 1}$ & fcc & 65 & 159 & 410 & [39] & no eq. \\
\hline$\underline{\mathrm{Al}_{7}} \underline{\mathrm{Co}_{2}} \underline{\mathrm{Cr}_{23}} \underline{\mathrm{Fe}_{23}} \underline{\mathrm{Ni}_{23}}$ & as-cast & fcc & $\sim 58$ & $\sim 210$ & $\sim 500$ & {$[115]$} & no hom. \\
\hline $\mathrm{Al}_{2} \mathrm{Co}_{18} \mathrm{Cr}_{18} \mathrm{Cu}_{18} \mathrm{Fe}_{18} \mathrm{Ni}_{18}$ & $\mathrm{cr}$ & fcc & $\sim 5$ & $\sim 1290$ & $\sim 1400$ & [114] & no eq. \\
\hline$\underline{\mathrm{Co}_{35}} \mathrm{Cr}_{15} \mathrm{Fe}_{20} \mathrm{Mo}_{10} \mathrm{Ni}_{20}$ & $\begin{array}{l}1200^{\circ} \mathrm{C} 48 \mathrm{~h} \\
\text { forged } 700^{\circ} \mathrm{C}\end{array}$ & fcc & 21.9 & 350 & 720 & [85] & \\
\hline equiatomic $\mathrm{CoCrFeMnNi}$ & - & fcc & 50 & 243 & 558 & {$[38]$} & no eq. \\
\hline equiatomic $\mathrm{CoCrFeMnNi}$ & $\begin{array}{c}1000^{\circ} \mathrm{C} 6 \mathrm{~h} \\
\text { forged } 700^{\circ} \mathrm{C} \\
-1000^{\circ} \mathrm{C} 6 \mathrm{~h} \\
-\mathrm{cr}-900^{\circ} \mathrm{C} 6 \\
\mathrm{~h}\end{array}$ & fcc & 41 & 249 & 621 & {$[38]$} & no eq. \\
\hline equiatomic $\mathrm{CoCrFeMnNi}$ & $\begin{array}{c}1200^{\circ} \mathrm{C} 48 \mathrm{~h}- \\
\mathrm{cr}- \\
800^{\circ} \mathrm{C} 1 \mathrm{~h}\end{array}$ & fcc & 56 & 370 & 670 & [8] & no eq. \\
\hline equiatomic $\underline{\mathrm{CoCrFeMnNi}}$ & as-cast & fcc & 62 & 209 & 496 & [115] & no hom. \\
\hline equiatomic $\mathrm{CoCrFeNi}$ & $1200^{\circ} \mathrm{C} 4 \mathrm{~h}$ & fcc & 70 & $\sim 190$ & 453 & {$[78]$} & $\begin{array}{l}\text { composition } \\
\text { out of limits }\end{array}$ \\
\hline equiatomic $\mathrm{CoCrFeNi}$ & as-cast & fcc & 58.9 & 155 & 472.4 & [79] & $\begin{array}{c}\text { no hom., no } \\
\text { grain size }\end{array}$ \\
\hline
\end{tabular}

Table 26: Tensile properties at RT for several alloys (mostly multi-phase CCA) proposed to have good mechanical properties. Elongation to failure $\left(\varepsilon_{f}\right)$, yield strength (YS), ultimate tensile strength (UTS) tested at room temperature. Alloys with detected single phase have been underlined and serve as a reference. (cr: cold rolling, wq: water quenched, ac: air-cooled, no eq.: not in a state close to equilibrium, no hom.: no homogenization treatment carried out)

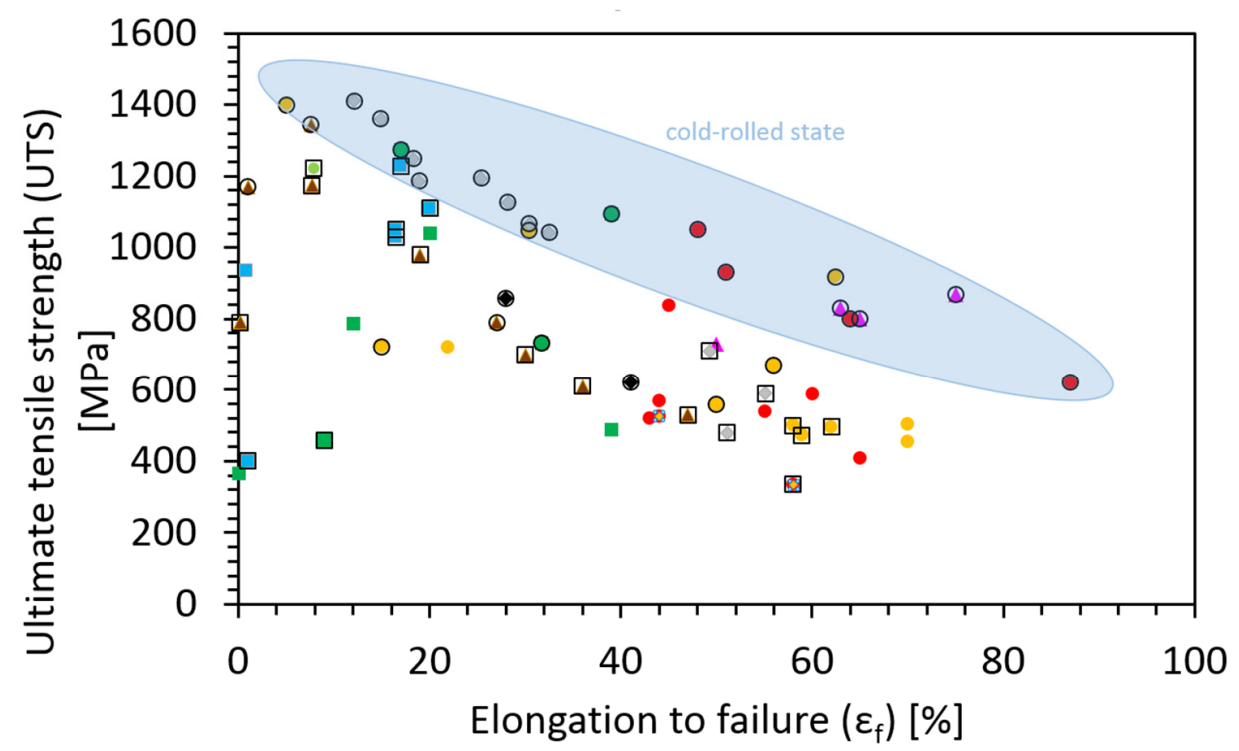

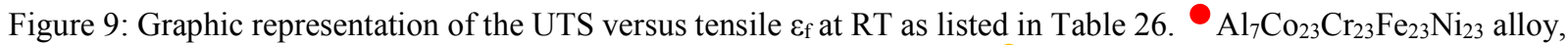

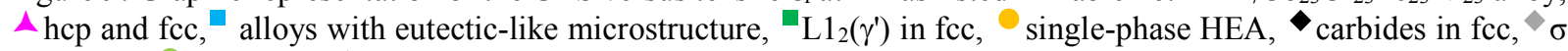
or $\mu$ in fcc, $B 2$ in bcc, $\triangle$ non attributable data; $\square$ as-cast alloys, $\bigcirc$ cold-rolled or forged alloys

The major conclusion that can be drawn from Figure 9 and Table 26is two-fold: Firstly, the well-known fact that if UTS is increased the elongation to failure decreases and secondly that additional mechanical treatment, in this case cold rolling (work hardening) increases the mechanical RT properties significantly (blue cloud, markers with black circle), independent of alloy composition and microstructure. 
Best properties of the group $\mathrm{L}_{2}\left(\gamma^{\prime}\right)$ in fcc matrix are the ones investigated by $\mathrm{He}$ et al. [78]. Single phase HEA can also show very good UTS $/ \varepsilon_{f}$ combinations after cold rolling, which shows the high impact of the cold-rolling compared to the precipitation strengthening. But none of these good results obtained by coldrolling fulfil the criterion of equilibrium listed in Table 2 . The metastable state, which is achieved after coldrolling, can only be used in certain applications such as sheets or rods and can never be used in a complex geometry where casting is necessary. It is also not advised to use this method for high temperature applications, because of the high strain at the beginning of the deformation process, due to the high initial dislocation density and usually small fracture strains (due to previously introduced damage).

Another metastable state, i.e. the as-cast state, is also very often shown in Figure 9. Only a few data points correspond to states that are neither as-cast nor cold rolled and therefore in a state closer to equilibrium. Figure 10 shows these data points in comparison.

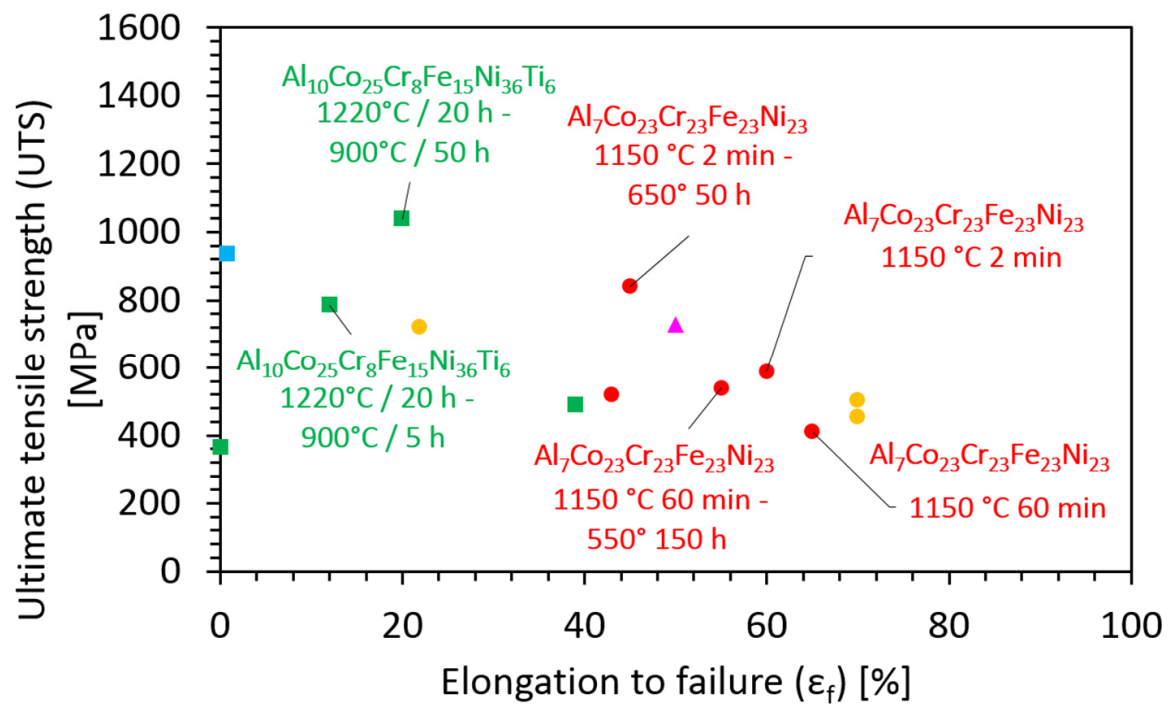

Figure 10: UTS versus tensile $\varepsilon_{\mathrm{f}}$ at room temperature of heat treated alloys in a state close to equilibrium. ${ }^{-} \mathrm{Al}_{7} \mathrm{Co}_{23} \mathrm{Cr}_{23} \mathrm{Fe}_{23} \mathrm{Ni}_{23}$ alloy, $\Delta$ hcp and fcc, ${ }^{\square}$ alloys with eutectic-like microstructures, ${ }^{\square} 1_{2}$ in fcc, ${ }^{\circ}$ single phase alloys.

This graph is dominated by three groups in different states: $\mathrm{Al}_{8} \mathrm{Co}_{17} \mathrm{Cr}_{17} \mathrm{Cu}_{8} \mathrm{Fe}_{17} \mathrm{Ni}_{33}, \mathrm{Al}_{10} \mathrm{Co}_{25} \mathrm{Cr}_{8} \mathrm{Fe}_{15} \mathrm{Ni}_{36} \mathrm{Ti}_{6}$ $[28,30,89]$ and $\mathrm{Al}_{7} \mathrm{Co}_{23} \mathrm{Cr}_{23} \mathrm{Fe}_{23} \mathrm{Ni}_{23}$ [39], that fulfil the criteria of Table 2. 


\subsection{Tensile properties at $700^{\circ} \mathrm{C}$}

One important possibility for two- or multi-phase CCA is the application at elevated temperatures. Since most of the data was available at $700^{\circ} \mathrm{C}$, the results for this temperature will be presented. Table 27 summarizes the available tension test data with selected commercial alloys. Figure 11shows the graphical representation.

\begin{tabular}{|c|c|c|c|c|c|c|c|}
\hline Alloy & Specimen state & $\begin{array}{c}\text { Phases } \\
\text { detected }\end{array}$ & $\begin{array}{c}\varepsilon_{\mathbf{f}} \\
{[\%]}\end{array}$ & $\begin{array}{c}\text { YS } \\
{[\mathrm{MPa}]}\end{array}$ & $\begin{array}{l}\text { UTS } \\
{[\mathrm{MPa}]}\end{array}$ & Ref. & Comment \\
\hline \multicolumn{8}{|c|}{ Alloys with eutectic-like microstructure } \\
\hline equiatomic $\mathrm{AlCoCrFeNi}$ & as-cast & $\mathrm{bcc}+\mathrm{B} 2$ & 1 & 395 & 400 & {$[72]$} & no hom. \\
\hline equiatomic $\mathrm{AlCoCrFeNi}$ & $\begin{array}{l}\mathrm{HP} 1150^{\circ} \mathrm{C} \\
50 \mathrm{~h}\end{array}$ & $\begin{array}{c}\mathrm{bcc}+\mathrm{B} 2+\mathrm{fcc} \\
+\sigma\end{array}$ & 12 & 295 & 393 & {$[72]$} & \\
\hline \multicolumn{8}{|c|}{ Non attributable influence } \\
\hline $\begin{array}{c}\text { equiatomic } \\
\text { AlCoCrCuFeNi }\end{array}$ & as-cast & $\begin{array}{c}\mathrm{bcc}+\mathrm{fcc} 1+ \\
\mathrm{fcc} 2\end{array}$ & 5 & 350 & 360 & {$[42]$} & $\begin{array}{c}\text { missing phases, } \\
\text { see [47] }\end{array}$ \\
\hline $\begin{array}{c}\text { equiatomic } \\
\mathrm{AlCoCrCuFeNi}\end{array}$ & forged $950^{\circ} \mathrm{C}$ & $\begin{array}{l}\mathrm{bcc}+\mathrm{fcc} 1+ \\
\mathrm{fcc} 2+\sigma\end{array}$ & 63 & 63 & 91 & {$[42]$} & no eq. \\
\hline $\mathrm{Al}_{\underline{2}} \underline{\mathrm{Co}} \underline{18} \underline{\mathrm{Cr}_{18}} \underline{\mathrm{Cu}} \underline{18}{ }_{\mathrm{Fe}_{18}} \underline{\mathrm{Ni}} \underline{18}$ & $\underline{\mathrm{cr}}$ & $\mathrm{fcc}$ & 5 & 180 & 185 & [114] & no eq. \\
\hline $\mathrm{Al}_{9} \mathrm{Co}_{18} \mathrm{Cr}_{18} \mathrm{Cu}_{18} \mathrm{Fe}_{18} \mathrm{Ni}_{18}$ & $\mathrm{cr}-900^{\circ} \mathrm{C} 5 \mathrm{~h}$ & $\mathrm{fcc} 1+\mathrm{fcc} 2$ & 12 & 160 & 180 & [114] & no hom. \\
\hline \multicolumn{8}{|c|}{ L1 2 in fcc and Al-rich needle shape phase } \\
\hline $\mathrm{Al}_{10} \mathrm{Co}_{25} \mathrm{Cr}_{8} \mathrm{Fe}_{15} \mathrm{Ni}_{36} \mathrm{Ti}_{6}$ & $\begin{array}{c}1220^{\circ} \mathrm{C} 20 \mathrm{~h}- \\
900^{\circ} \mathrm{C} 5 \mathrm{~h}\end{array}$ & $\mathrm{fcc}+\mathrm{L}_{2}+\mathrm{C}_{1}$ & 18 & 487 & 702 & {$[30]$} & \\
\hline $\mathrm{Al}_{10} \mathrm{Co}_{25} \mathrm{Cr}_{8} \mathrm{Fe}_{15} \mathrm{Ni}_{36} \mathrm{Ti}_{6}$ & $\begin{array}{c}1220^{\circ} \mathrm{C} 20 \mathrm{~h}- \\
900^{\circ} \mathrm{C} 50 \mathrm{~h} \\
\end{array}$ & $\mathrm{fcc}+\mathrm{L}_{2}+\mathrm{C}_{1}$ & 11 & 486 & 624 & {$[30]$} & \\
\hline \multicolumn{8}{|c|}{$B 2$ in $b c c$} \\
\hline $\mathrm{Al}_{12} \mathrm{Cr}_{18} \mathrm{Co}_{18} \mathrm{Fe}_{36} \mathrm{Ni}_{18}$ & as-cast & $\mathrm{bcc}+\mathrm{B} 2$ & 5.4 & 220 & 340 & {$[77]$} & no hom. \\
\hline \multicolumn{8}{|c|}{ single phase HEA } \\
\hline $\mathrm{Al}_{9} \mathrm{Co}_{18} \mathrm{Cr}_{18} \mathrm{Cu}_{18} \mathrm{Fe}_{18} \mathrm{Ni}_{18}$ & $\underline{\mathrm{cr}}$ & fcc & 5 & 180 & 185 & {$[114]$} & no eq. \\
\hline \multicolumn{8}{|c|}{ Commercial alloys } \\
\hline Duplex stainless steel & & & 2.4 & 329 & 366 & {$[116]$} & \\
\hline 304 stainless steel & & & 9.1 & 179 & 248 & [116] & \\
\hline Ni-based Inconel 690 & & & 26 & 150 & 478 & {$[117]$} & \\
\hline ODS steel $0.3 \%$ Yttria & & & 11 & 210 & 272 & [118] & \\
\hline Intermetallics FeAl 787 & & & 18 & 345 & 350 & [119] & \\
\hline Alloy $800 \mathrm{H}$ & hot forged & & 38 & 405 & 872 & {$[120]$} & no eq. \\
\hline IN617 & $\begin{array}{l}\text { extruded + } \\
\text { annealed }\end{array}$ & & 35 & 109 & 329 & {$[121]$} & no eq. \\
\hline
\end{tabular}

Table 27: Tensile properties at $700^{\circ} \mathrm{C}$ for several high temperature structural materials. Elongation to failure $\left(\varepsilon_{\mathrm{f}}\right)$, yield strength (YS), ultimate tensile strength (UTS)(cr: cold rolling, wq: water quenched, ac: air-cooled, no eq.: not in a state close to equilibrium, no hom.: no homogenization treatment carried out) 


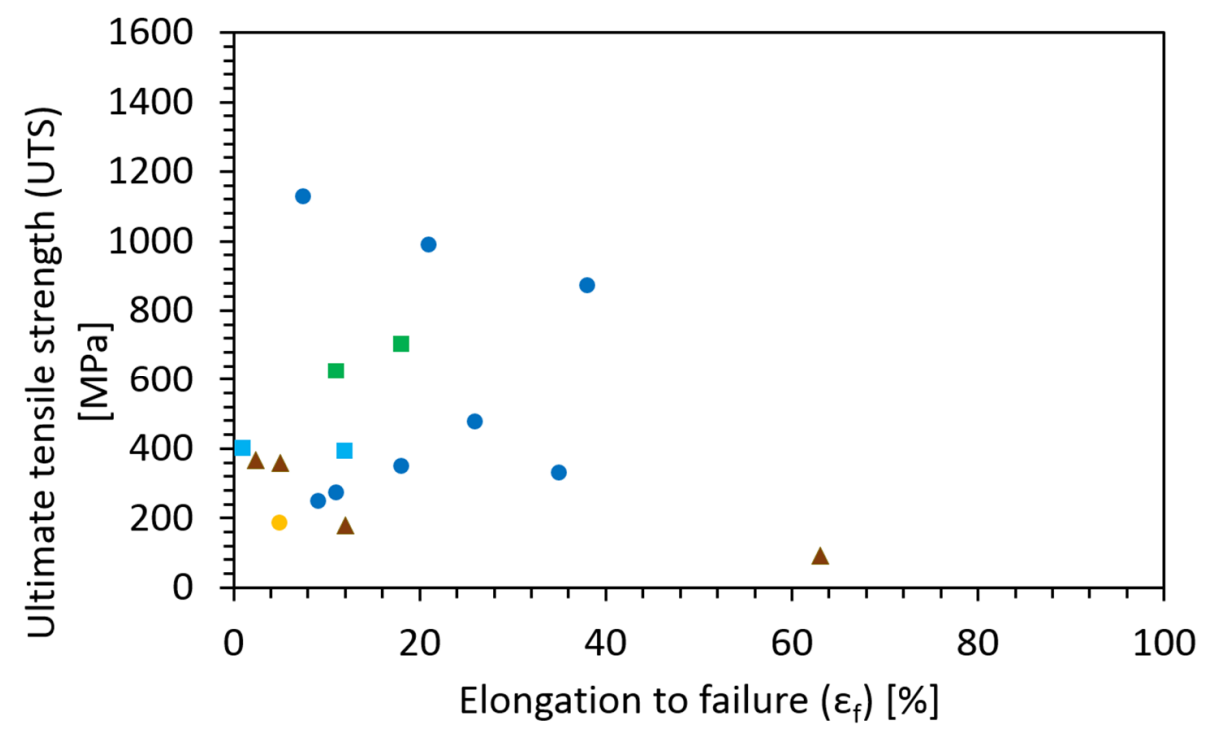

Figure 11: UTS versus tensile $\varepsilon_{\mathrm{f}}$ at $700^{\circ} \mathrm{C}$ of the alloys summarized in Table $27 .{ }^{\circ}$ commercial alloys, ${ }^{\square}$ eutectic alloys, $\mathrm{L}_{2}$ in fcc, single phase alloys, $\Delta$ non attributable data

In this graph the three-phase $\mathrm{CCA} \mathrm{Al}_{10} \mathrm{Co}_{25} \mathrm{Cr}_{8} \mathrm{Fe}_{15} \mathrm{Ni}_{36} \mathrm{Ti}_{6}$ is the best non-commercial alloy. 


\section{Summary and conclusion}

This review provides an overview over multi-phase compositionally complex alloys (CCA) and for some single-phase high entropy alloys (HEA). Focus is on mechanical properties at room and elevated temperatures. Research within the last few years have raised the awareness that the understanding of the mechanical behaviour of CCA and HEA will need a common base on carefully documenting all steps from composition, processing, thermo-mechanical heat treatment, sample preparation and testing. A comparison of the investigations in the equiatomic $\mathrm{AlCoCrCuFeNi}$ alloy (Table 3) shows the importance of microstructural investigations at different scales and in all regions of the observed alloy.

A set of eight criteria has been established at the beginning of this manuscript in Table 2.Even though many of the literature used and cited in this review do not fulfil all these criteria, some general conclusions can be drawn from this comparison.

When comparing the results from mechanical testing, especially in tension testing at RT and $700^{\circ} \mathrm{C}$, some general observations, valid for many decades, have been reproduced within the CCA and HEA research. Increasing UTS leads to decreasing elongation to failure, the well-known "banana-like behaviour", if one plots UTS versus elongation to failure (Figure 9, Figure 10 and Figure 11). The second one is, regardless of composition, one can increase strength by the usual strengthening mechanisms, especially at RT. In this review mainly cold-rolling was observed (see Figure 9).This work hardening strengthening mechanism is an effect, which is completely independent of the CCA and HEA concept and has to be regarded as an additional measure.

Compositionally complex alloys (CCA) with eutectic-like microstructure show their strength in the fact that they can be used in the as-cast state and thus reducing a time and cost intensive processing step. Due to their - in this case - phase, not grain boundary hardening, these compositions show high ultimate tensile strength (UTS) and relatively low elongation to failure $\left(\varepsilon_{\mathrm{f}}\right)$.

The best mechanical results in this review on CCA and HEA at elevated temperature $\left(700^{\circ} \mathrm{C}\right)$ have been obtained by compositions and heat treatments which result in a microstructure similar to that of the wellknown Ni-base superalloys. The best candidates with this respect are the two- or three-phase compositionally complex alloys (CCA): $\mathrm{Al}_{7} \mathrm{Co}_{23} \mathrm{Cr}_{23} \mathrm{Fe}_{23} \mathrm{Ni}_{23}$ and $\mathrm{Al}_{10} \mathrm{Co}_{25} \mathrm{Cr}_{8} \mathrm{Fe}_{15} \mathrm{Ni}_{36} \mathrm{Ti}_{6}$.

Finally, and unfortunately, it has to be stated that, at the time when this review was finished, none of the CCA and HEA mentioned in this paper have better mechanical properties in tension testing at RT and $700^{\circ} \mathrm{C}$ than readily available commercial alloys. In this review, no cost considerations have been conducted to check if the raw material costs can be decreased. Further progress is necessary to check if a niche of properties can be identified in which CCA or HEA show a better mechanical performance than existing alloys.

\section{Acknowledgement}

The authors are grateful to the German Research foundation (DFG) for the financial support by MA 7004/1, as well as GL 181/50 and through the Priority Programme SPP 2006 "Compositionally Complex Alloys High Entropy Alloys (CCA - HEA)". Many thanks to Sebastian Haas from Metals and Alloys group in Bayreuth, Germany, who has supported this work by additional literature research. 


\section{References}

[1] J.W. Yeh, Nano-structured high-entropy alloys, Knowl. Bridge, 40 (2003) 1-2.

[2] J.W. Yeh, S.K. Chen, J.Y. Gan, S.J. Lin, T.S. Chin, T.T. Shun, C.H. Tsau, S.Y. Chang, Formation of simple crystal structures in Cu-Co-Ni-Cr-Al-Fe-Ti-V alloys with multiprincipal metallic elements, Metal. Mater. Trans A - Physical Metallurgy and Materials Science, 35A (2004) 2533-2536.

[3] J.W. Yeh, S.K. Chen, S.J. Lin, J.Y. Gan, T.S. Chin, T.T. Shun, C.H. Tsau, S.Y. Chang, Nanostructured highentropy alloys with multiple principal elements: Novel alloy design concepts and outcomes, Adv. Eng. Mater., 6 (2004) 299-303.

[4] B. Cantor, F. Audebert, M. Galano, K.B. Kim, I.C. Stone, P.J. Warren, Novel multicomponent alloys, in: A. Inoue (Ed.) Metastable, Mechanically Alloyed and Nanocrystalline Materials, 2005, pp. 1-5.

[5] B. Cantor, I.T.H. Chang, P. Knight, A.J.B. Vincent, Microstructural development in equiatomic multicomponent alloys, Mater. Sci. Eng., A, 375 (2004) 213-218.

[6] S. Ranganathan, Alloyed pleasures: Multimetallic cocktails, Curr Sci, 85 (2003) 1404-1406.

[7] A. Gali, E.P. George, Tensile properties of high- and medium-entropy alloys, Intermetallics, 39 (2013) 74-78.

[8] F. Otto, A. Dlouhy, C. Somsen, H. Bei, G. Eggeler, E.P. George, The influences of temperature and microstructure on the tensile properties of a CoCrFeMnNi high-entropy alloy, Acta. Mater., 61 (2013) 5743-5755.

[9] http://www.sppccahea.uni-bayreuth.de/en/index.html, 2018.

[10] O.N. Senkov, G.B. Wilks, D.B. Miracle, C.P. Chuang, P.K. Liaw, Refractory high-entropy alloys, Intermetallics, 18 (2010) 1758-1765.

[11] O.N. Senkov, J.M. Scott, S.V. Senkova, D.B. Miracle, C.F. Woodward, Microstructure and room temperature properties of a high-entropy TaNbHfZrTi alloy, J. Alloys Compd., 509 (2011) 6043-6048.

[12] M. Feuerbacher, M. Heidelmann, C. Thomas, Hexagonal High-entropy Alloys, Mater. Res. Lett., 3 (2015) 1-6.

[13] K.S. Lee, B. Bae, J.H. Kang, K.R. Lim, Y.S. Na, Multi-phase refining of an AlCoCrFeNi high entropy alloy by hot compression, Mater. Lett., 198 (2017) 81-84.

[14] F. Otto, N.L. Hanold, E.P. George, Microstructural evolution after thermomechanical processing in an equiatomic, single-phase CoCrFeMnNi high-entropy alloy with special focus on twin boundaries, Intermetallics, 54 (2014) 39-48.

[15] Z. Wu, H. Bei, F. Otto, G.M. Pharr, E.P. George, Recovery, recrystallization, grain growth and phase stability of a family of FCC-structured multi-component equiatomic solid solution alloys, Intermetallics, 46 (2014) 131-140.

[16] Z. Li, C.C. Tasan, H. Springer, B. Gault, D. Raabe, Interstitial atoms enable joint twinning and transformation induced plasticity in strong and ductile high-entropy alloys, 7 (2017) 40704.

[17] Z. Li, K.G. Pradeep, Y. Deng, D. Raabe, C.C. Tasan, Metastable high-entropy dual-phase alloys overcome the strength-ductility trade-off, Nature, (2016).

[18] Z.M. Li, C.C. Tasan, K.G. Pradeep, D. Raabe, A TRIP-assisted dual-phase high-entropy alloy: Grain size and phase fraction effects on deformation behavior, Acta. Mater., 131 (2017) 323-335.

[19] A.R. Jones, Annealing twinning and the nucleation of recrystallization at grain boundaries, J. Mater. Sci., 16 (1981) 1374-1380.

[20] J.Y. He, Q. Wang, H.S. Zhang, L.H. Dai, T. Mukai, Y. Wu, X.J. Liu, H. Wang, T.G. Nieh, Z.P. Lu, Dynamic deformation behavior of a face-centered cubic FeCoNiCrMn high-entropy alloy, Sci. Bull., 63 (2018) 362368.

[21] D. Choudhuri, S. Shukla, W.B. Green, B. Gwalani, V. Ageh, R. Banerjee, R.S. Mishra, Crystallographically degenerate B2 precipitation in a plastically deformed fcc-based complex concentrated alloy, Mater. Res. Lett., 6 (2018) 171-177. 
[22] G.S. Firstov, T.A. Kosorukova, Y.N. Koval, V.V. Odnosum, High Entropy Shape Memory Alloys, Materials Today: Proceedings, 2 (2015) S499-S503.

[23] L. Ma, L. Wang, Z. Nie, F. Wang, Y. Xue, J. Zhou, T. Cao, Y. Wang, Y. Ren, Reversible deformationinduced martensitic transformation in Al0.6CoCrFeNi high-entropy alloy investigated by in situ synchrotron-based high-energy X-ray diffraction, Acta. Mater., 128 (2017) 12-21.

[24] G. Firstov, A. Timoshevski, T. Kosorukova, Y. Koval, Y. Matviychuk, P. Verhovlyuk, Electronic and crystal structure of the high entropy TiZrHfCoNiCu intermetallics undergoing martensitic transformation, in: N. Schryvers, J. VanHumbeeck (Eds.) Esomat 2015 - 10th European Symposium on Martensitic Transformations, 2015.

[25] T.K. Liu, Z. Wu, A.D. Stoica, Q. Xie, W. Wu, Y.F. Gao, H. Bei, K. An, Twinning-mediated work hardening and texture evolution in CrCoFeMnNi high entropy alloys at cryogenic temperature, Materials \& Design, 131 (2017) 419-427.

[26] The Version TCCR, ThermoCalc Software AB, http://www.thermocalc.com, Stockholm, Sweden, 2006.

[27] Thermotech Ni-based Superalloys Database, TTNI7, Thermo-Calc Software AB, Stockholm, Sweden, 2006.

[28] A.M. Manzoni, S. Singh, H.M. Daoud, R. Popp, R. Völkl, U. Glatzel, N. Wanderka, On the Path to Optimizing the Al-Co-Cr-Cu-Fe-Ni-Ti High Entropy Alloy Family for High Temperature Applications, Entropy, 18 (2016) 104.

[29] A. Manzoni, H. Daoud, S. Mondal, S. van Smaalen, R. Völkl, U. Glatzel, N. Wanderka, Investigation of phases in $\mathrm{Al} 23 \mathrm{Co} 15 \mathrm{Cr} 23 \mathrm{Cu} 8 \mathrm{Fe} 15 \mathrm{Ni} 16$ and $\mathrm{Al} 8 \mathrm{Co} 17 \mathrm{Cr} 17 \mathrm{Cu} 8 \mathrm{Fe} 17 \mathrm{Ni3} 3$ high entropy alloys and comparison with equilibrium phases predicted by Thermo-Calc, J. Alloys Compd., 552 (2013) 430-436.

[30] H.M. Daoud, A.M. Manzoni, N. Wanderka, U. Glatzel, High-Temperature Tensile Strength of Al10Co25Cr8Fe15Ni36Ti6 Compositionally Complex Alloy (High-Entropy Alloy), JOM, 67 (2015) 22712277.

[31] Y. Zhang, S.G. Ma, J.W. Qiao, Morphology Transition from Dendrites to Equiaxed Grains for AlCoCrFeNi High-Entropy Alloys by Copper Mold Casting and Bridgman Solidification, Metal. Mater. Trans A - Physical Metallurgy and Materials Science, 43A (2012) 2625-2630.

[32] Y.P. Lu, Y. Dong, S. Guo, L. Jiang, H.J. Kang, T.M. Wang, B. Wen, Z.J. Wang, J.C. Jie, Z.Q. Cao, H.H. Ruan, T.J. Li, A Promising New Class of High-Temperature Alloys: Eutectic High-Entropy Alloys, Scientific Reports, 4 (2014).

[33] A. Manzoni, H. Daoud, R. Völkl, U. Glatzel, N. Wanderka, Phase separation in equiatomic AlCoCrFeNi high-entropy alloy, Ultramicroscopy, 132 (2013) 212-215.

[34] S.S. Nene, K. Liu, M. Frank, R.S. Mishra, R.E. Brennan, K.C. Cho, Z. Li, D. Raabe, Enhanced strength and ductility in a friction stir processing engineered dual phase high entropy alloy, Scientific Reports, 7 (2017).

[35] E.O. Hall, The Deformation and Ageing of Mild Steel: III Discussion of Results, Proceedings of the Physical Society. Section B, 64 (1951) 747.

[36] N.J. Petch, The cleavage strength of polycrystals, Journal of the Iron and Steel Institute, 174 (1953) 25-28.

[37] S.J. Sun, Y.Z. Tian, H.R. Lin, H.J. Yang, X.G. Dong, Y.H. Wang, Z.F. Zhang, Transition of twinning behavior in CoCrFeMnNi high entropy alloy with grain refinement, Mat. Sci. Eng. A - Structural Materials Properties Microstructure and Processing, 712 (2018) 603-607.

[38] H. Cheng, H.Y. Wang, Y.C. Xie, Q.H. Tang, P.Q. Dai, Controllable fabrication of a carbide-containing FeCoCrNiMn high-entropy alloy: microstructure and mechanical properties, Mater. Sci. Technol., (2017) 1-8.

[39] B. Gwalani, V. Soni, M. Lee, S.A. Mantri, Y. Ren, R. Banerjee, Optimizing the coupled effects of HallPetch and precipitation strengthening in a Al0.3CoCrFeNi high entropy alloy, Materials \& Design, 121 (2017) 254-260. 
[40] B. Gwalani, V. Soni, D. Choudhuri, M. Lee, J.Y. Hwang, S.J. Nam, H. Ryu, S.H. Hong, R. Banerjee, Stability of ordered L12 and B2 precipitates in face centered cubic based high entropy alloys -

Al0.3CoFeCrNi and Al0.3CuFeCrNi2, Scripta Mater., 123 (2016) 130-134.

[41] I.S. Wani, T. Bhattacharjee, S. Sheikh, Y.P. Lu, S. Chatterjee, P.P. Bhattacharjee, S. Guo, N. Tsuji, Ultrafine-Grained AlCoCrFeNi2.1 Eutectic High-Entropy Alloy, Mater. Res. Lett., 4 (2016) 174-179.

[42] A.V. Kuznetsov, D.G. Shaysultanov, N.D. Stepanov, G.A. Salishchev, O.N. Senkov, Tensile properties of an $\mathrm{AlCrCuNiFeCo}$ high-entropy alloy in as-cast and wrought conditions, Mat. Sci. Eng. A - Structural Materials Properties Microstructure and Processing, 533 (2012) 107-118.

[43] C.J. Tong, Y.L. Chen, S.K. Chen, J.W. Yeh, T.T. Shun, C.H. Tsau, S.J. Lin, S.Y. Chang, Microstructure characterization of AlxCoCrCuFeNi high-entropy alloy system with multiprincipal elements, Metall. Mater. Trans. A, 36A (2005) 881-893.

[44] J.M. Zhu, H.F. Zhang, H.M. Fu, A.M. Wang, H. Li, Z.Q. Hu, Microstructures and compressive properties of multicomponent AlCoCrCuFeNiMo(x)under-bar alloys, J. Alloys Compd., 497 (2010) 52-56.

[45] L.H. Wen, H.C. Kou, J.S. Li, H. Chang, X.Y. Xue, L. Zhou, Effect of aging temperature on microstructure and properties of AlCoCrCuFeNi high-entropy alloy, Intermetallics, 17 (2009) 266-269.

[46] D.G. Shaysultanov, N.D. Stepanov, A.V. Kuznetsov, G.A. Salishchev, O.N. Senkov, Phase Composition and Superplastic Behavior of a Wrought AlCoCrCuFeNi High-Entropy Alloy, JOM, 65 (2013) 1815-1828.

[47] S. Singh, N. Wanderka, B.S. Murty, U. Glatzel, J. Banhart, Decomposition in multi-component AlCoCrCuFeNi high-entropy alloy, Acta. Mater., 59 (2011) 182-190.

[48] X.F. Wang, Y. Zhang, Y. Qiao, G.L. Chen, Novel microstructure and properties of multicomponent CoCrCuFeNiTix alloys, Intermetallics, 15 (2007) 357-362.

[49] Y. Dong, Y. Lu, J. Kong, J. Zhang, T. Li, Microstructure and mechanical properties of multi-component AlCrFeNiMox high-entropy alloys, J. Alloys Compd., 573 (2013) 96-101.

[50] H. Jiang, L. Jiang, K. Han, Y. Lu, T. Wang, Z. Cao, T. Li, Effects of Tungsten on Microstructure and Mechanical Properties of CrFeNiV0.5W x and CrFeNi2V0.5W x High-Entropy Alloys, J. Mater. Eng. Perform., 24 (2015) 4594-4600.

[51] S.Z. Niu, H.C. Kou, T. Guo, Y. Zhang, J. Wang, J.S. Li, Strengthening of nanoprecipitations in an annealed Al0.5CoCrFeNi high entropy alloy, Mat. Sci. Eng. A - Structural Materials Properties Microstructure and Processing, 671 (2016) 82-86.

[52] S.-Z. Niu, H.-C. Kou, J. Wang, J.-S. Li, Improved tensile properties of Al0.5CoCrFeNi high-entropy alloy by tailoring microstructures, Rare Metals, (2017).

[53] L. Jiang, H. Jiang, Y.P. Lu, T.M. Wang, Z.Q. Cao, T.J. Li, Mechanical Properties Improvement of AlCrFeNi2Ti0.5 High Entropy Alloy through Annealing Design and its Relationship with its Particlereinforced Microstructures, Journal of Materials Science \& Technology, 31 (2015) 397-402.

[54] B. Gorr, F. Muller, M. Azim, H.J. Christ, T. Muller, H. Chen, A. Kauffmann, M. Heilmaier, HighTemperature Oxidation Behavior of Refractory High-Entropy Alloys: Effect of Alloy Composition, Oxid. Met., 88 (2017) 339-349.

[55] B. Gorr, M. Azim, H.J. Christ, T. Mueller, D. Schliephake, M. Heilmaier, Phase equilibria, microstructure, and high temperature oxidation resistance of novel refractory high-entropy alloys, J. Alloys Compd., 624 (2015) 270-278.

[56] D.T. Pierce, J.A. Jimenez, J. Bentley, D. Raabe, C. Oskay, J.E. Wittig, The influence of manganese content on the stacking fault and austenite/epsilon-martensite interfacial energies in Fe-Mn-(Al-Si) steels investigated by experiment and theory, Acta. Mater., 68 (2014) 238-253.

[57] Y.-F. Kao, T.-J. Chen, S.-K. Chen, J.-W. Yeh, Microstructure and mechanical property of as-cast, homogenized, and -deformed AlxCoCrFeNi (0 $\leq x \leq 2)$ high-entropy alloys, J. Alloys Compd., 488 (2009) 5764.

[58] W.-R. Wang, W.-L. Wang, S.-C. Wang, Y.-C. Tsai, C.-H. Lai, J.-W. Yeh, Effects of Al addition on the microstructure and mechanical property of AlxCoCrFeNi high-entropy alloys, Intermetallics, 26 (2012) 4451. 
[59] C. Zhang, F. Zhang, H. Diao, M.C. Gao, Z. Tang, J.D. Poplawsky, P.K. Liaw, Understanding phase stability of Al-Co-Cr-Fe-Ni high entropy alloys, Materials \& Design, 109 (2016) 425-433.

[60] H.Y. Yasuda, H. Miyamoto, K. Cho, T. Nagase, Formation of ultrafine-grained microstructure in Al0.3CoCrFeNi high entropy alloys with grain boundary precipitates, Mater. Lett., 199 (2017) 120-123.

[61] J.C. Rao, H.Y. Diao, V. Ocelík, D. Vainchtein, C. Zhang, C. Kuo, Z. Tang, W. Guo, J.D. Poplawsky, Y.

Zhou, P.K. Liaw, J.T.M. De Hosson, Secondary phases in AlxCoCrFeNi high-entropy alloys: An in-situ TEM heating study and thermodynamic appraisal, Acta. Mater., 131 (2017) 206-220.

[62] T.T. Shun, Y.C. Du, Microstructure and tensile behaviors of FCC Al(0.3)CoCrFeNi high entropy alloy, J. Alloys Compd., 479 (2009) 157-160.

[63] W.-R. Wang, W.-L. Wang, J.-W. Yeh, Phases, microstructure and mechanical properties of AlxCoCrFeNi high-entropy alloys at elevated temperatures, J. Alloys Compd., 589 (2014) 143-152.

[64] Q. Tang, Y. Huang, H. Cheng, X. Liao, T.G. Langdon, P. Dai, The effect of grain size on the annealinginduced phase transformation in an Al0.3CoCrFeNi high entropy alloy, Materials \& Design, 105 (2016) 381-385.

[65] H.Y. Yasuda, K. Shigeno, T. Nagase, Dynamic strain aging of Al0.3CoCrFeNi high entropy alloy single crystals, Scripta Mater., 108 (2015) 80-83.

[66] M.E. Glicksman, Principles of Solidification: An Introduction to Modern Casting and Crystal Growth Concepts, Springer Verlag, New York, 2010.

[67] L.Y. Lin, T.H. Courtney, Direct observations of lamellar fault migration in the Pb-Sn eutectic, MT, 5 (1974) 513-514.

[68] G. Sharma, R.V. Ramanujan, G.P. Tiwari, Instability mechanisms in lamellar microstructures, Acta. Mater., 48 (2000) 875-889.

[69] R.W. Balluffi, S. Allen, W.C. Carter, Kinetics of Materials, John Wiley \& Sons, 2005.

[70] A. Munitz, S. Salhov, S. Hayun, N. Frage, Heat treatment impacts the micro-structure and mechanical properties of AlCoCrFeNi high entropy alloy, J. Alloys Compd., 683 (2016) 221-230.

[71] E. Ghassemali, R. Sonkusare, K. Biswas, N.P. Gurao, In-situ study of crack initiation and propagation in a dual phase AICoCrFeNi high entropy alloy, J. Alloys Compd., 710 (2017) 539-546.

[72] Z. Tang, O.N. Senkov, C.M. Parish, C. Zhang, F. Zhang, L.J. Santodonato, G.Y. Wang, G.F. Zhao, F.Q. Yang, P.K. Liaw, Tensile ductility of an AlCoCrFeNi multi-phase high-entropy alloy through hot isostatic pressing (HIP) and homogenization, Mat. Sci. Eng. A - Structural Materials Properties Microstructure and Processing, 647 (2015) 229-240.

[73] Y. Dong, X.X. Gao, Y.P. Lu, T.M. Wang, T.J. Li, A multi-component AlCrFe2Ni2 alloy with excellent mechanical properties, Mater. Lett., 169 (2016) 62-64.

[74] Y.P. Lu, X.Z. Gao, L. Jiang, Z.N. Chen, T.M. Wang, J.C. Jie, H.J. Kang, Y.B. Zhang, S. Guo, H.H. Ruan, Y.H. Zhao, Z.Q. Cao, T.J. Li, Directly cast bulk eutectic and near-eutectic high entropy alloys with balanced strength and ductility in a wide temperature range, Acta. Mater., 124 (2017) 143-150.

[75] X. Chen, J.Q. Qi, Y.W. Sui, Y.Z. He, F.X. Wei, Q.K. Meng, Z. Sun, Effects of aluminum on microstructure and compressive properties of Al-Cr-Fe-Ni eutectic multi-component alloys, Mat. Sci. Eng. A - Structural Materials Properties Microstructure and Processing, 681 (2017) 25-31.

[76] Z.G. Wang, W. Zhou, L.M. Fu, J.F. Wang, R.C. Luo, X.C. Han, B. Chen, X.D. Wang, Effect of coherent L12 nanoprecipitates on the tensile behavior of a fcc-based high-entropy alloy, Materials Science and Engineering: A, 696 (2017) 503-510.

[77] Q. Wang, Y. Ma, B.B. Jiang, X.N. Li, Y. Shi, C. Dong, P.K. Liaw, A cuboidal B2 nanoprecipitationenhanced body-centered-cubic alloy Al0.7CoCrFe2Ni with prominent tensile properties, Scripta Mater., 120 (2016) 85-89.

[78] J.Y. He, H. Wang, H.L. Huang, X.D. Xu, M.W. Chen, Y. Wu, X.J. Liu, T.G. Nieh, K. An, Z.P. Lu, A precipitation-hardened high-entropy alloy with outstanding tensile properties, Acta. Mater., 102 (2016) 187-196. 
[79] W.H. Liu, Z.P. Lu, J.Y. He, J.H. Luan, Z.J. Wang, B. Liu, Y. Liu, M.W. Chen, C.T. Liu, Ductile CoCrFeNiMox high entropy alloys strengthened by hard intermetallic phases, Acta. Mater., 116 (2016) 332-342.

[80] F. He, Z.J. Wang, S.Z. Niu, Q.F. Wu, J.J. Li, J.C. Wang, C.T. Liu, Y.Y. Dang, Strengthening the CoCrFeNiNb0.25 high entropy alloy by FCC precipitate, J. Alloys Compd., 667 (2016) 53-57. [81] N.D. Stepanov, D.G. Shaysultanov, M.S. Ozerov, S.V. Zherebtsov, G.A. Salishchev, Second phase formation in the CoCrFeNiMn high entropy alloy after recrystallization annealing, Mater. Lett., 185 (2016) 1-4.

[82] N.D. Stepanov, D.G. Shaysultanov, G.A. Salishchev, M.A. Tikhonovsky, Structure and mechanical properties of a light-weight AINbTiV high entropy alloy, Mater. Lett., 142 (2015) 153-155.

[83] N.D. Stepanov, D.G. Shaysultanov, G.A. Salishchev, M.A. Tikhonovsky, E.E. Oleynik, A.S. Tortika, O.N. Senkov, Effect of $\mathrm{V}$ content on microstructure and mechanical properties of the CoCrFeMnNiVx high entropy alloys, J. Alloys Compd., 628 (2015) 170-185.

[84] N.D. Stepanov, N.Y. Yurchenko, S.V. Zherebtsov, M.A. Tikhonovsky, G.A. Salishchev, Aging behavior of the HfNbTaTiZr high entropy alloy, Mater. Lett., (2017).

[85] K.S. Ming, X.F. Bi, J. Wang, Precipitation strengthening of ductile Cr15Fe20Co35Ni20Mo10 alloys, Scripta Mater., 137 (2017) 88-93.

[86] H.M. Daoud, A. Manzoni, R. Volkl, N. Wanderka, U. Glatzel, Microstructure and Tensile Behavior of Al8Co17Cr17Cu8Fe17Ni33 (at.\%) High-Entropy Alloy, JOM, 65 (2013) 1805-1814.

[87] H.M. Daoud, A.M. Manzoni, R. Voelkl, N. Wanderka, U. Glatzel, Oxidation Behavior of Al8Co17Cr17Cu8Fe17Ni33, Al23Co15Cr23Cu8Fe15Ni15, and Al17Co17Cr17Cu17Fe17Ni17 Compositionally Complex Alloys (High-Entropy Alloys) at Elevated Temperatures in Air, Adv. Eng. Mater., 17 (2015) 1134-1141.

[88] A.M. Manzoni, H.M. Daoud, R. Voelkl, U. Glatzel, N. Wanderka, Influence of W, Mo and Ti trace elements on the phase separation in Al8Co17Cr17Cu8Fe17Ni33 based high entropy alloy, Ultramicroscopy, 159, Part 2 (2015) 265-271.

[89] A.M. Manzoni, S. Singh, H.M. Daoud, R. Völkl, U. Glatzel, N. Wanderka, On the Optimization of the Microstructure and Mechanical Properties of Al-Co-Cr-Cu-Fe-Ni-Ti-Based High Entropy Alloys, The Jordan Journal of Physics, 8 (3) (2015) 177-186.

[90] O.N. Senkov, J.M. Scott, S.V. Senkova, F. Meisenkothen, D.B. Miracle, C.F. Woodward, Microstructure and elevated temperature properties of a refractory TaNbHfZrTi alloy, J. Mater. Sci., 47 (2012) 4062-4074.

[91] O.N. Senkov, S.L. Semiatin, Microstructure and properties of a refractory high-entropy alloy after cold working, J. Alloys Compd., 649 (2015) 1110-1123.

[92] J.P. Couzinie, L. Lilensten, Y. Champion, G. Dirras, L. Perriere, I. Guillot, On the room temperature deformation mechanisms of a TiZrHfNbTa refractory high-entropy alloy, Mat. Sci. Eng. A - Structural Materials Properties Microstructure and Processing, 645 (2015) 255-263.

[93] W.Q. Wu, S. Ni, Y. Liu, M. Song, Effects of cold rolling and subsequent annealing on the microstructure of a HfNbTaTiZr high-entropy alloy, J. Mater. Res., 31 (2016) 3815-3823.

[94] H.U. Rehman, K. Durst, S. Neumeier, A.B. Parsa, A. Kostka, G. Eggeler, M. Göken, Nanoindentation studies of the mechanical properties of the mu phase in a creep deformed Re containing nickel-based superalloy, Mat. Sci. Eng. A - Structural Materials Properties Microstructure and Processing, 634 (2015) 202-208.

[95] C.M.F. Rae, R.C. Reed, The precipitation of topologically close-packed phases in rhenium-containing superalloys, Acta. Mater., 49 (2001) 4113-4125.

[96] D.G. Shaysultanov, N.D. Stepanov, G.A. Salishchev, M.A. Tikhonovsky, Effect of heat treatment on the structure and hardness of high-entropy alloys CoCrFeNiMnV $(x)(x=0.25,0.5,0.75,1)$, Physics of Metals and Metallography, 118 (2017) 579-590. 
[97] R.C. Reed, The Superalloys. Fundamentals and Applications, Cambridge University Press, Cambridge, 2006.

[98] M. Durand-Charre, The microstructure of Superalloys, CRC Press, Boca Raton, London, New York, Washington D.C., 1997.

[99] X.D. Xu, P. Liu, S. Guo, A. Hirata, T. Fujita, T.G. Nieh, C.T. Liu, M.W. Chen, Nanoscale phase separation in a fcc-based CoCrCuFeNiAl0.5 high-entropy alloy, Acta. Mater., 84 (2015) 145-152.

[100] S. Singh, N. Wanderka, K. Kiefer, K. Siemensmeyer, J. Banhart, Effect of decomposition of the CrFe-Co rich phase of AlCoCrCuFeNi high entropy alloy on magnetic properties, Ultramicroscopy, 111 (2011) 619-622.

[101] M.-H. Tsai, H. Yuan, G. Cheng, W. Xu, K.-Y. Tsai, C.-W. Tsai, W.W. Jian, C.-C. Juan, W.-J. Shen, M.-H. Chuang, J.-W. Yeh, Y.T. Zhu, Morphology, structure and composition of precipitates in Al0.3CoCrCu0.5FeNi high-entropy alloy, Intermetallics, 32 (2013) 329-336.

[102] N.G. Jones, A. Frezza, H.J. Stone, Phase equilibria of an Al0.5CrFeCoNiCu High Entropy Alloy, Mater. Sci. Eng., A, 615 (2014) 214-221.

[103] C.W. Tsai, Y.L. Chen, M.H. Tsai, J.W. Yeh, T.T. Shun, S.K. Chen, Deformation and annealing behaviors of high-entropy alloy Al0.5CoCrCuFeNi, J. Alloys Compd., 486 (2009) 427-435.

[104] A.C. Yeh, T.K. Tsao, Y.J. Chang, K.C. Chang, J.W. Yeh, M.S. Chiou, S.R. Jian, C.M. Kuo, W.R. Wang, H. Murakami, Developing New Type of High Temperature Alloys-High Entropy Superalloys International Journal of Metallurgical \& Materials Engineering, 1 (2015) 107.

[105] A.C. Yeh, Y.J. Chang, C.W. Tsai, Y.C. Wang, J.W. Yeh, C.M. Kuo, On the Solidification and Phase Stability of a Co-Cr-Fe-Ni-Ti High-Entropy Alloy, Metal. Mater. Trans A - Physical Metallurgy and Materials Science, 45A (2014) 184-190.

[106] N. Kamikawa, K. Sato, G. Miyamoto, M. Murayama, N. Sekido, K. Tsuzaki, T. Furuhara, Stress-strain behavior of ferrite and bainite with nano-precipitation in low carbon steels, Acta. Mater., 83 (2015) 383396.

[107] Y.Y. Zhao, H.W. Chen, Z.P. Lu, T.G. Nieh, Thermal stability and coarsening of coherent particles in a precipitation-hardened (NiCoFeCr)(94)Ti2Al4 high-entropy alloy, Acta. Mater., 147 (2018) 184-194.

[108] B. Gwalani, D. Choudhuri, V. Soni, Y. Ren, M. Styles, J.Y. Hwang, S.J. Nam, H. Ryu, S.H. Hong, R. Banerjee, $\mathrm{Cu}$ assisted stabilization and nucleation of L1(2) precipitates in Al0.3CuFeCrNi2 fcc-based high entropy alloy, Acta. Mater., 129 (2017) 170-182.

[109] Y. Dong, K.Y. Zhou, Y. Lu, X.X. Gao, T.M. Wang, T.J. Li, Effect of vanadium addition on the microstructure and properties of AlCoCrFeNi high entropy alloy, Materials \& Design, 57 (2014) 67-72. [110] S.G. Ma, Z.M. Jiao, J.W. Qiao, H.J. Yang, Y. Zhang, Z.H. Wang, Strain rate effects on the dynamic mechanical properties of the AlCrCuFeNi2 high-entropy alloy, Mat. Sci. Eng. A - Structural Materials Properties Microstructure and Processing, 649 (2016) 35-38.

[111] J. Joseph, T. Jarvis, X.H. Wu, N. Stanford, P. Hodgson, D.M. Fabijanic, Comparative study of the microstructures and mechanical properties of direct laser fabricated and arc-melted AlxCoCrFeNi high entropy alloys, Mat. Sci. Eng. A - Structural Materials Properties Microstructure and Processing, 633 (2015) 184-193.

[112] G.A. Salishchev, M.A. Tikhonovsky, D.G. Shaysultanov, N.D. Stepanov, A.V. Kuznetsov, I.V. Kolodiy, A.S. Tortika, O.N. Senkov, Effect of $\mathrm{Mn}$ and $\mathrm{V}$ on structure and mechanical properties of high-entropy alloys based on CoCrFeNi system, J. Alloys Compd., 591 (2014) 11-21.

[113] Z. Tang, T. Yuan, C.W. Tsai, J.W. Yeh, C.D. Lundin, P.K. Liaw, Fatigue behavior of a wrought Al0.5CoCrCuFeNi two-phase high-entropy alloy, Acta. Mater., 99 (2015) 247-258.

[114] C.-W. Tsai, M.-H. Tsai, J.-W. Yeh, C.-C. Yang, Effect of temperature on mechanical properties of Al0.5CoCrCuFeNi wrought alloy, J. Alloys Compd., 490 (2010) 160-165.

[115] J.Y. He, W.H. Liu, H. Wang, Y. Wu, X.J. Liu, T.G. Nieh, Z.P. Lu, Effects of Al addition on structural evolution and tensile properties of the FeCoNiCrMn high-entropy alloy system, Acta. Mater., 62 (2014) 105-113. 
[116] J. Chen, B. Young, B. Uy, Behavior of high strength structural steel at elevated temperatures, J. Struct. Eng.-ASCE, 132 (2006) 1948-1954.

[117] V. Venkatesh, H.J. Rack, Elevated temperature hardening of INCONEL 690, Mech. Mater., 30 (1998) 69-81.

[118] R. Schaeublin, T. Leguey, P. Spatig, N. Baluc, M. Victoria, Microstructure and mechanical properties of two ODS ferritic/martensitic steels, J. Nucl. Mater., 307 (2002) 778-782.

[119] R.S. Sundar, S.C. Deevi, High-temperature strength and creep resistance of FeAl, Mat. Sci. Eng. A Structural Materials Properties Microstructure and Processing, 357 (2003) 124-133.

[120] http://www.sandmeyersteel.com/images/Alloy-800-Spec-Sheet.pdf, Sandmeyer steel company website.

[121] http://www.specialmetals.com/documents/Inconel\%20alloy\%20617.pdf, Special metals company website.

\section{Contents}

New Multiphase Compositionally Complex Alloys Driven by the High Entropy Alloy Approach............. 1

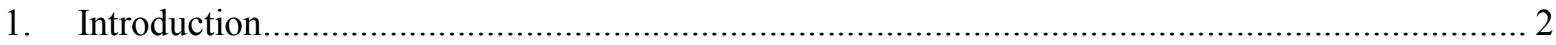

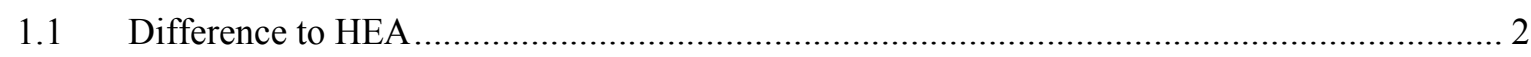

1.2 Alloy development for improving the mechanical properties ............................................ 3

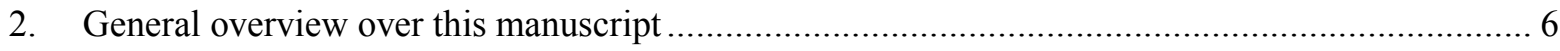

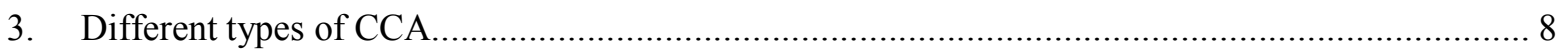

3.1 "Accidental CCA" / general interest .................................................................. 8

3.2 Industrial approach: production of larger quantities, stability over some composition range... 9

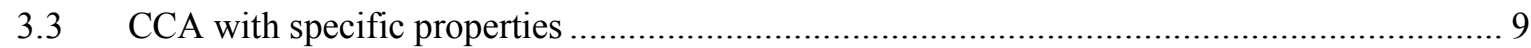

4. Overview and comparison of the tensile and compressive data of CCA....................................... 30

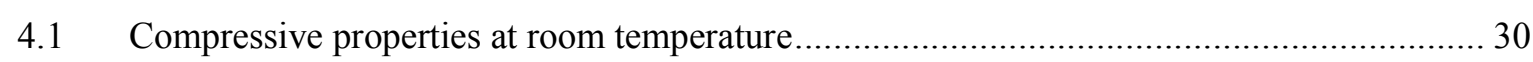

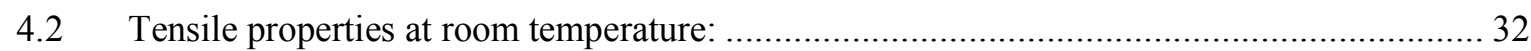

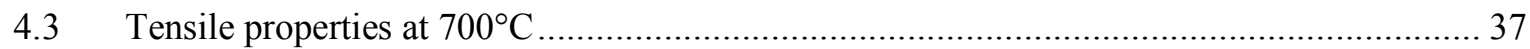

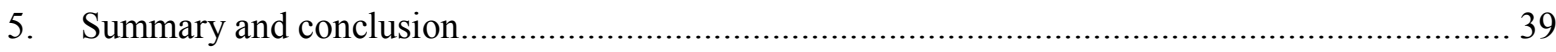

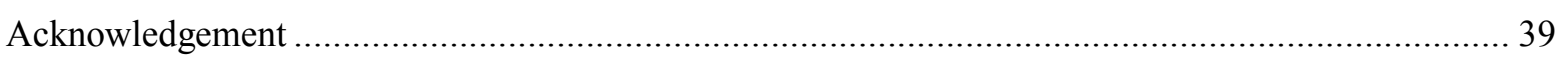

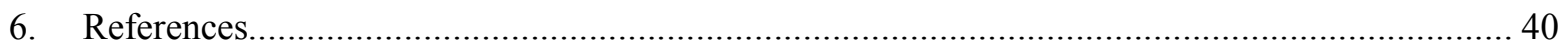

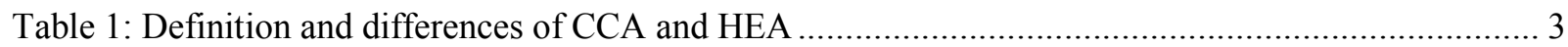

Table 2: Criteria that serve for comparing the investigated CCA …..................................................... 7

Table 3: Detected phases in the equiatomic as-cast alloy $\mathrm{AlCoCrCuFeNi}$........................................... 7

Table 4: Tensile engineering and true data of the different states of the equiatomic $\mathrm{CoCrFeMnNi}$ and the

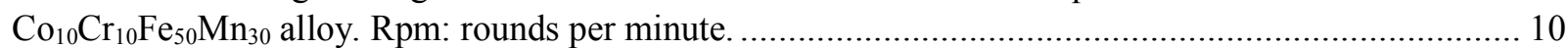

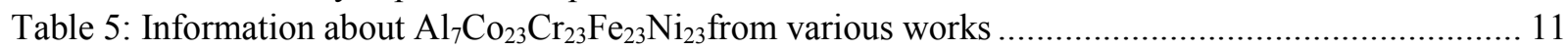

Table 6: Tensile data at room temperature of the cold rolled and recrystallized $\mathrm{Al}_{7} \mathrm{Co}_{23} \mathrm{Cr}_{23} \mathrm{Fe}_{23} \mathrm{Ni}_{23}$ alloy,

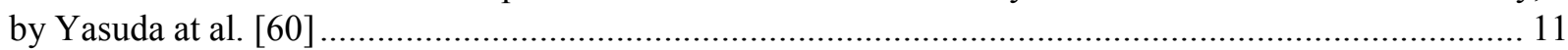

Table 7: Tensile data of the $\mathrm{Al}_{7} \mathrm{Co}_{23} \mathrm{Cr}_{23} \mathrm{Fe}_{23} \mathrm{Ni}_{23}$ alloy with and without $\mathrm{B} 2$ and $\mathrm{L} 1_{2}$ precipitates [39]... 12 46 
Table 8: Tensile data of the $\mathrm{Al}_{7} \mathrm{Co}_{23} \mathrm{Cr}_{23} \mathrm{Fe}_{23} \mathrm{Ni}_{23}$ alloy in three different states, with unknown grain size [62]......

Table 9: Observed phases in the equiatomic alloy $\mathrm{AlCoCrFeNi}$ after different heat treatments. The colour description and wording has been chosen by Munitz et al. and refers to their back-scattered electron images (see [70]).

Table 10: A summary of the compressive yield stress YS, compressive fracture strength $\sigma_{\mathrm{f}}$ and compressive uniform contraction $\varepsilon_{\mathrm{f}}$ for the equiatomic alloy $\mathrm{AlCoCrFeNi}$ alloy in the as-cast condition and after different heat treatments [70].

Table 11: Room temperature tensile data of the heat treated equiatomic CCA AlCoCrFeNi................... 18

Table 12: Tensile data of the as-cast $\mathrm{Al}_{17} \mathrm{Cr}_{17} \mathrm{Fe}_{33} \mathrm{Ni}_{33}$ alloy with eutectic-like microstructure at RT......... 18

Table 13: Tensile data for three alloys with varying Ni-content at different testing temperatures............. 18

Table 14: Tensile and compressive data for the as-cast $\mathrm{Al}_{12} \mathrm{Co}_{18} \mathrm{Cr}_{18} \mathrm{Fe}_{35} \mathrm{Ni}_{18}$ alloy at different testing temperatures [77]

Table 15: hcp phase volume fraction, size and micro-hardness in different states of the equiatomic alloy HfNbTaTiZr [84].

Table 16: Tensile data for the alloy $\mathrm{Co}_{35} \mathrm{Cr}_{15} \mathrm{Fe}_{20} \mathrm{Ni}_{20} \mathrm{Mo}_{10}$ after different thermo-mechanical treatments [85]. ac: air cooling; wq- water quenching; hr - hot rolling; cr - cold rolling.

Table 17: $\sigma$ or $\mu$ phase precipitate sizes, engineering yield strength (YS), ultimate tensile strength (UTS), and elongation $\left(\varepsilon_{\mathrm{f}}\right)$ for the as-cast $\mathrm{Co}_{\mathrm{y}} \mathrm{Cr}_{\mathrm{y}} \mathrm{Fe}_{\mathrm{y}} \mathrm{Ni}_{\mathrm{y}} \mathrm{Mo}_{\mathrm{x}}$, with $0 \leq \mathrm{x}<7$ and $\mathrm{y}=(100-\mathrm{x}) / 4$, alloys and the $\mathrm{Mo}_{0.3}$ alloy $60 \%$-rolled and annealed to different states [79].

Table 18: $\sigma$ precipitate sizes in five different alloys with varying $\mathrm{V}$ content after homogenization at $1100^{\circ} \mathrm{C} 24 \mathrm{~h}[96]$.

Table 19: $\sigma$ phase volume fraction and compression data in the $1000^{\circ} \mathrm{C} 24 \mathrm{~h}$ annealed state of alloys with varying $\mathrm{V}$ content [83].

Table 20: Carbon influence on tensile data in the Cantor equiatomic alloy CoCrFeMnNi [38]; cr: coldrolling.

Table 21: Phases and volume fractions of phases in different states of the $\mathrm{Al}_{4} \mathrm{Co}_{24} \mathrm{Cr}_{24} \mathrm{Fe}_{24} \mathrm{Ni}_{24} \mathrm{Ti}_{2}$ alloy and

the corresponding tensile data [78]: cr: cold rolling; wq: water quenching .....

Table 22: The yield strength (YS), ultimate tensile strength (UTS), and elongation $\left(\varepsilon_{\mathrm{f}}\right)$ for the homogenized - cold-rolled - annealed $\mathrm{Al}_{4} \mathrm{Co}_{19} \mathrm{Cr}_{19} \mathrm{Cu}_{4} \mathrm{Fe}_{19} \mathrm{Ni}_{37}$ alloy at room temperature [76]

Table 23: Hardness data (HV0.05) for three different, in most cases, two-phase CCA in different heat treatment conditions $[30,88]$.

Table 24: The yield strength (YS), ultimate tensile strength (UTS), and elongation to failure $\left(\varepsilon_{f}\right)$ in tension for different states of the $\mathrm{Al}_{8} \mathrm{Co}_{17} \mathrm{Cr}_{17} \mathrm{Cu}_{8} \mathrm{Fe}_{17} \mathrm{Ni}_{33}$ and $\mathrm{Al}_{10} \mathrm{Co}_{25} \mathrm{Cr}_{8} \mathrm{Fe}_{15} \mathrm{Ni}_{36} \mathrm{Ti}_{6} \mathrm{CCAat}$ room temperature and at $700^{\circ} \mathrm{C}$.

Table 25: Compressive properties and major crystal structures of some typical CCA at room temperature. Compressive elongation to failure $\left(\varepsilon_{\mathrm{f}}\right)$, yield strength $(\mathrm{YS})$, compressive fracture strength $\left(\sigma_{\mathrm{f}}\right) \ldots \ldots \ldots \ldots \ldots . . . . .31$ Table 26: Tensile properties at RT for several alloys (mostly multi-phase CCA) proposed to have good mechanical properties. Elongation to failure $\left(\varepsilon_{\mathrm{f}}\right)$, yield strength (YS), ultimate tensile strength (UTS) tested at room temperature. Alloys with detected single phase have been underlined and serve as a reference. (cr: cold rolling, wq: water quenched, ac: air-cooled, no eq.: not in a state close to equilibrium, no hom.: no homogenization treatment carried out).....

Table 27: Tensile properties at $700^{\circ} \mathrm{C}$ for several high temperature structural materials. Elongation to failure $\left(\varepsilon_{\mathrm{f}}\right.$ ), yield strength (YS), ultimate tensile strength (UTS)(cr: cold rolling, wq: water quenched, ac: air-cooled, no eq.: not in a state close to equilibrium, no hom.: no homogenization treatment carried out) 